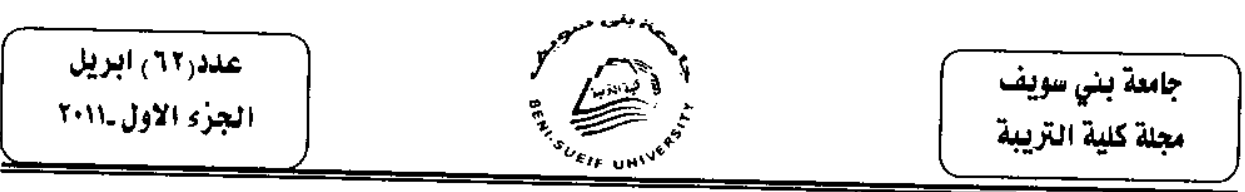

برنامج قائم على عادات العقل في تنمية الإقاء الثعرى والوعى بالموهبة لاى تلاميذ

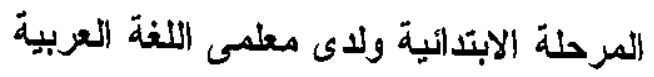

إعداد

د/ أيمن عيد بكرى محد العدال

مدرس بالمركز القومى للبحوث التربوية و التنمية

مقدمة البحث و أدبياته :

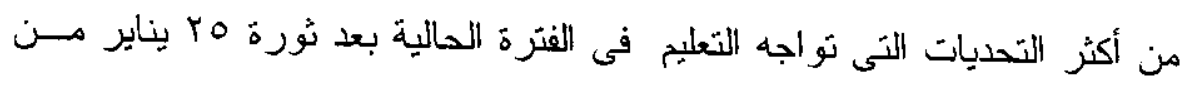

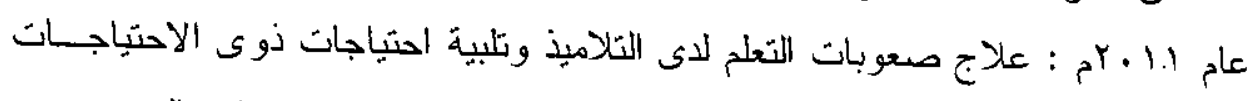

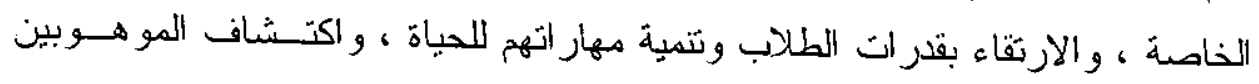

ور عايتهم.

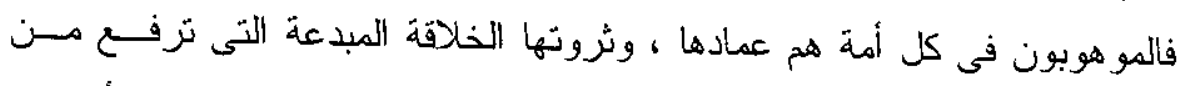

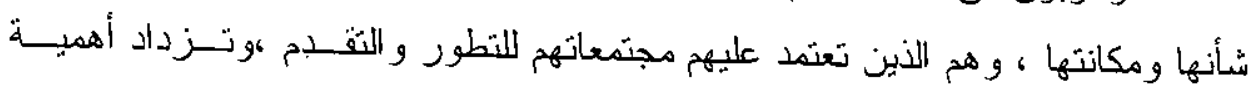

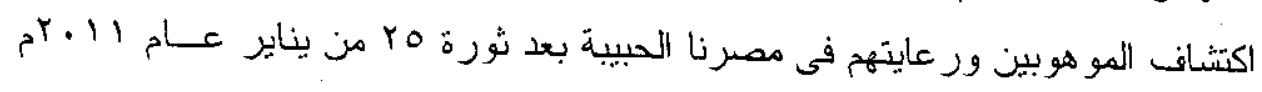

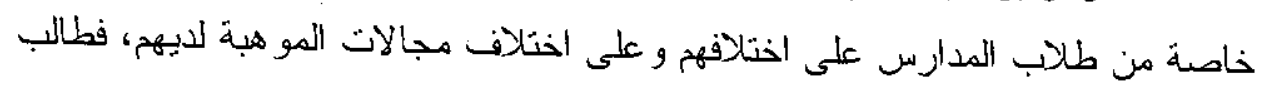

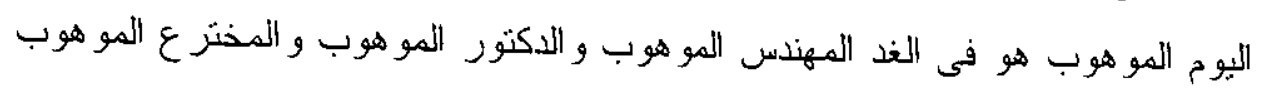

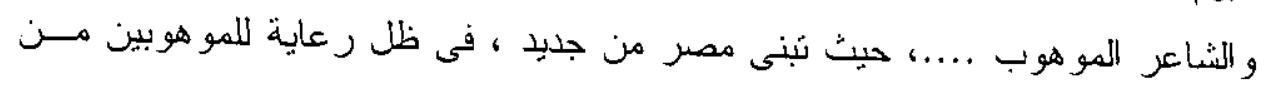
أبنائها الذين طالهم التهميش و النسيان فى عقود عجاف مانى ماضية.

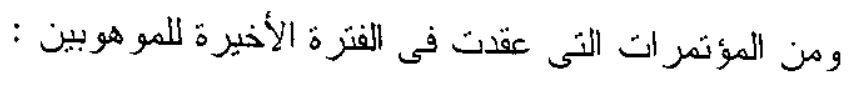

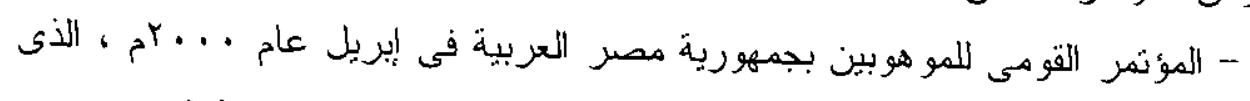

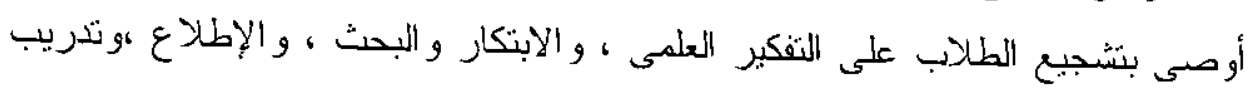
المعلمين على أساليب كثف المو هبة ور عايتها.

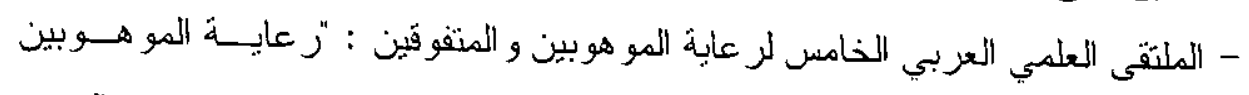

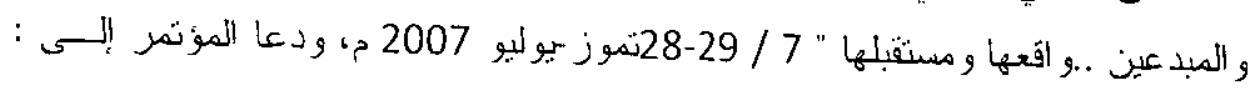




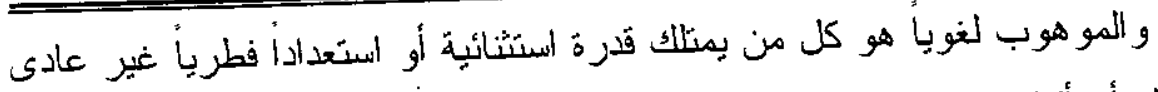

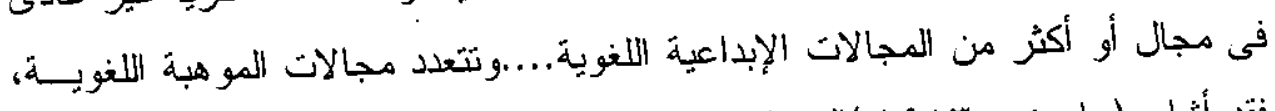

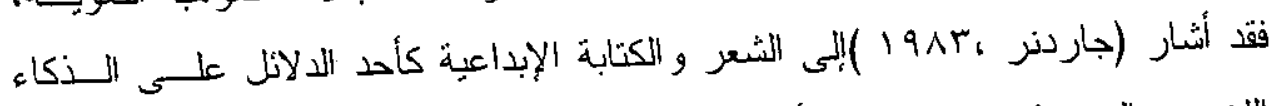

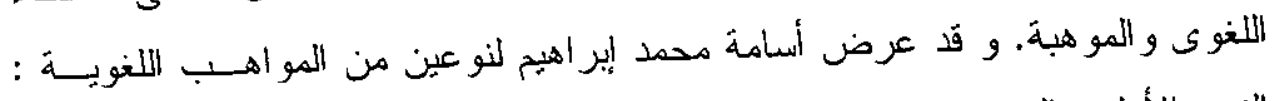

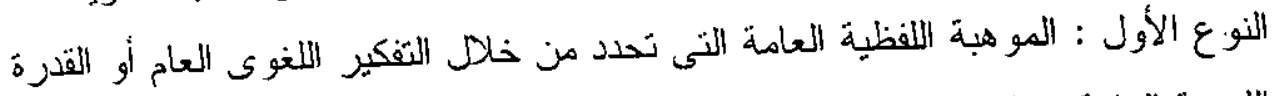

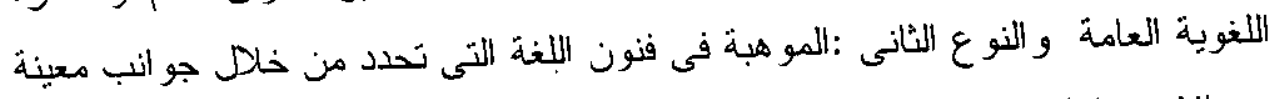

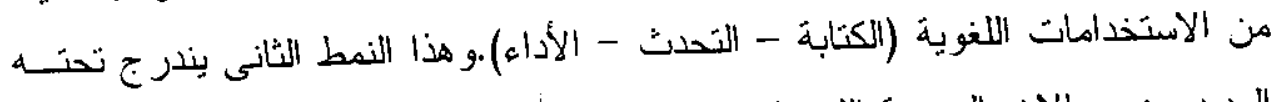

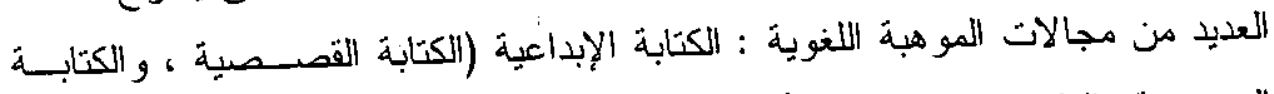

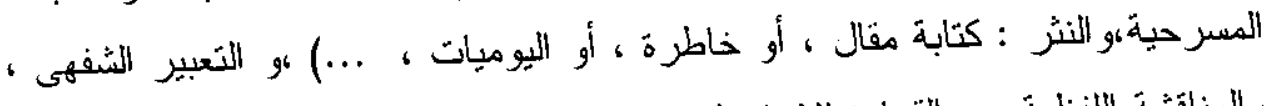

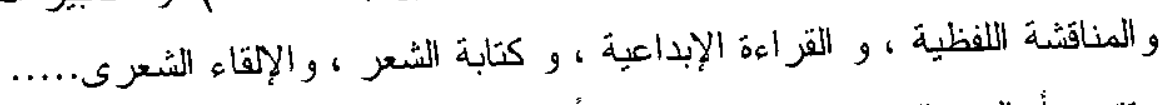

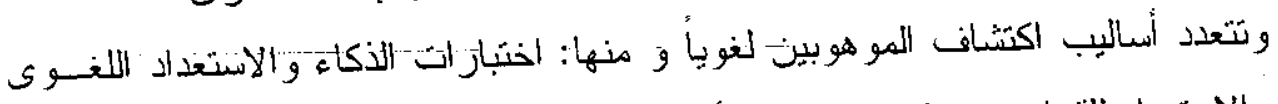
و الاستعداد للقز اءة .. و ولكن المدخل الأكثر جاذبية لاى كثير من المربين يتمثل في إنتاج

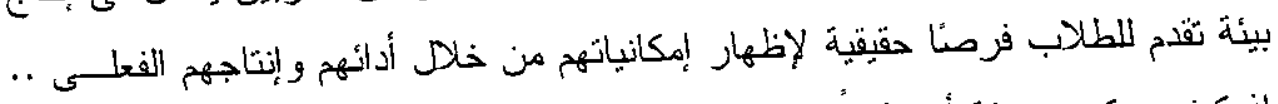

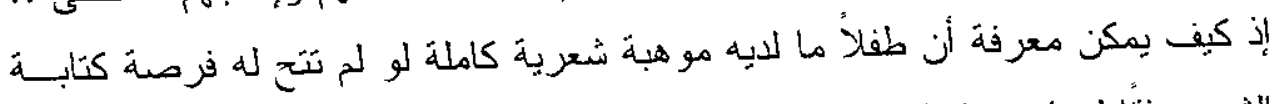

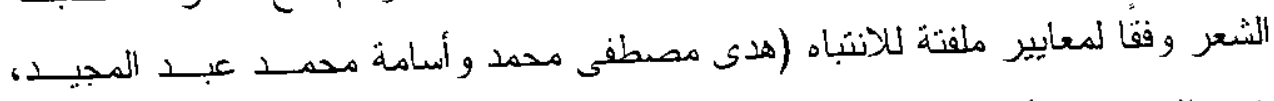

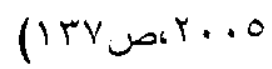
و يؤكد) (Van Tassel-Baska, Joyc,2008) على أستخدام أسالبِب منعددة في

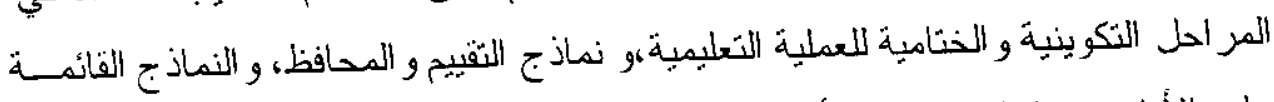
على الأداء، جنبا إلى جنب مع أفكار لبناء نموذج التقييم للمو هو بين في الفنون اللفية اللغوية.

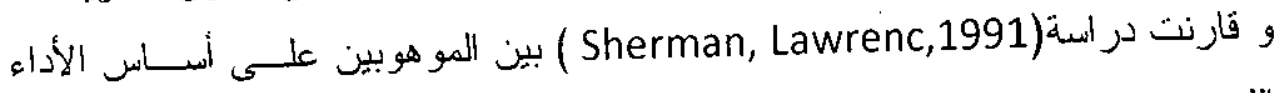

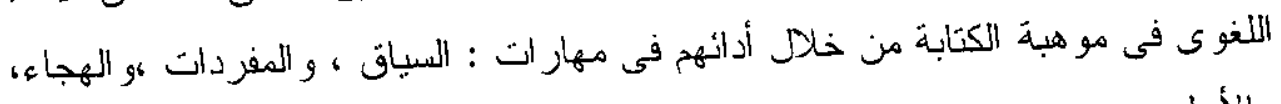
والأسلوب. 


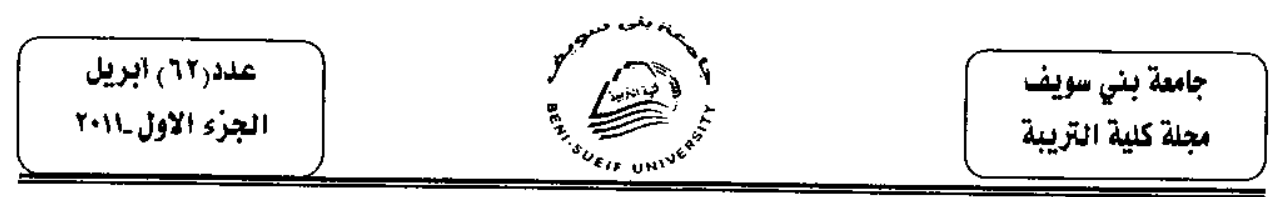

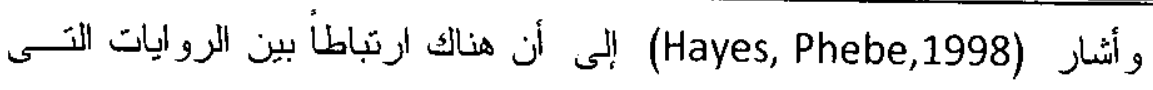

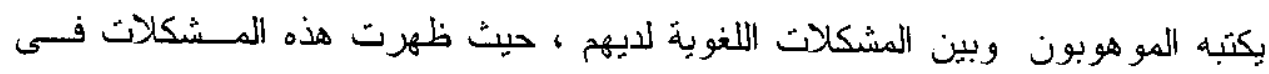

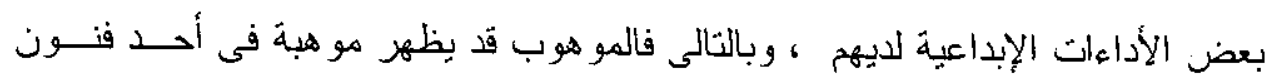

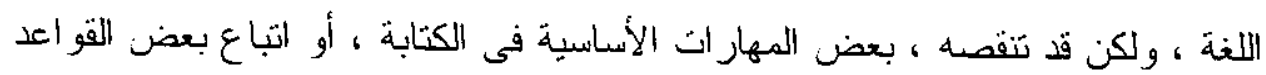

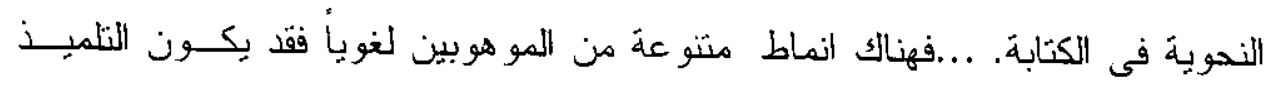

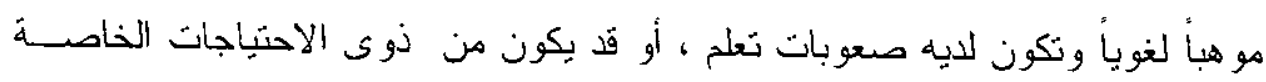

(Sherman, Lawrence, 1991)

ومن خلال تطبين ثمانية مقابيس لتحديد المو هوبين توصلت در اســة (2010,

(Matthews, Michael S المو هو بين لغويا غبر مناسبة ، و لا نكشف عن المو هبة الحقيقية للمو هو بين لغوباً.

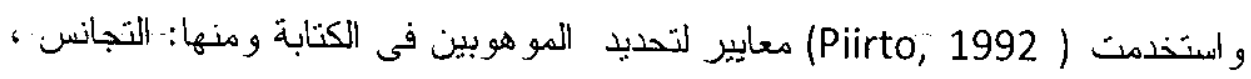

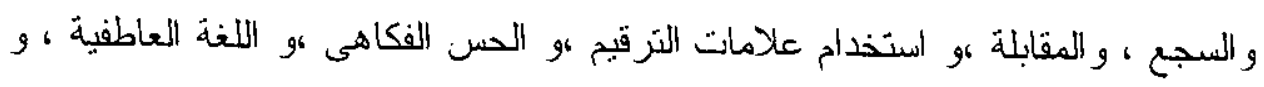

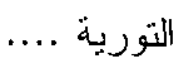

ونوصلت دراسة أسامة محمد عبد الحميد 199 1 إلى وجود علاقة ارتباطيه موجبة

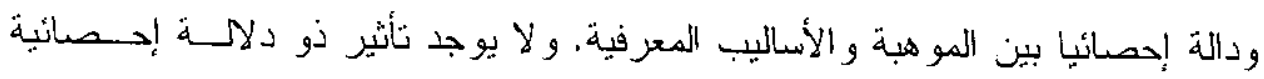

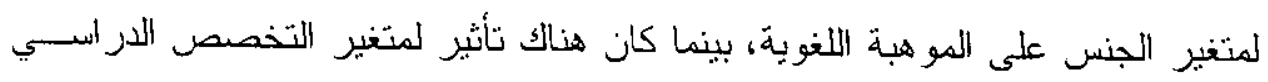

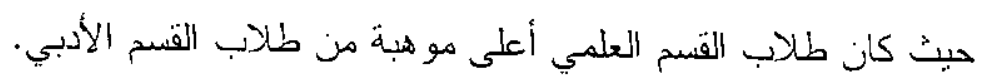

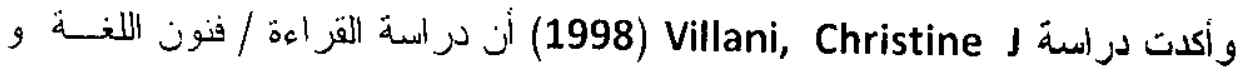

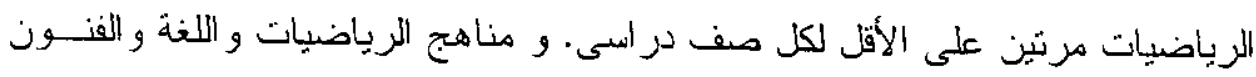

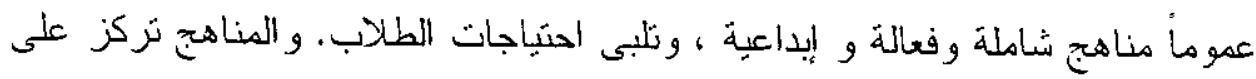

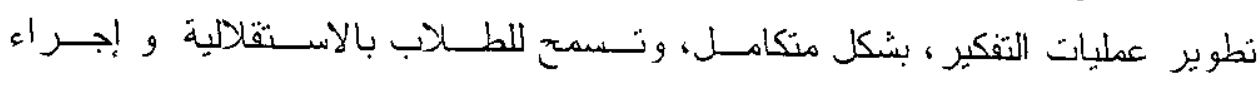

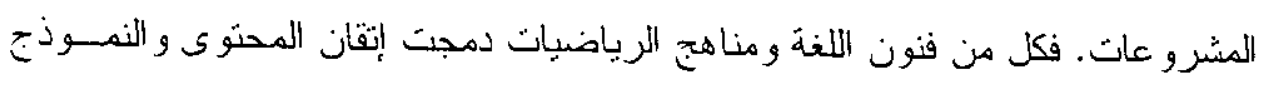

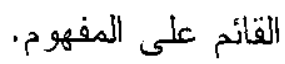




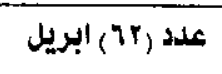

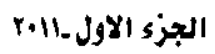

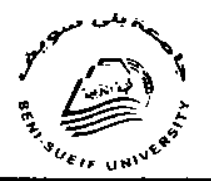

جامعة بني بسويف

مجلة كلية التريبة

و هدفت دراسة بشرى سالم نجــ (1 . . ب) إلقاء الضوء على الأغــانى و الأناشــبد المقدمة لطفل الروضة لتعرف مدى ملاعمنها للطفل من حبث: موضو عاتها ومجالاتها

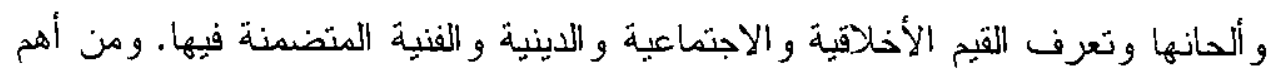

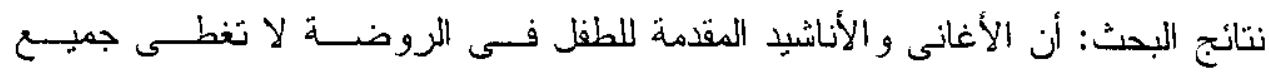

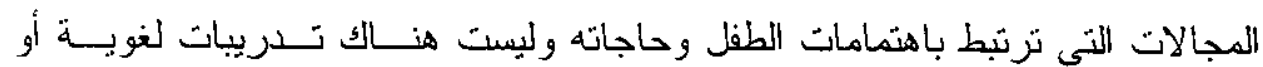

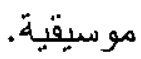
ومن أهم النتائج التى توصلت إليها دراسة Avery, Linda D

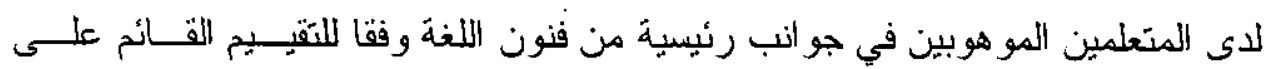
مهار ات التفكير العليا و الأداء.

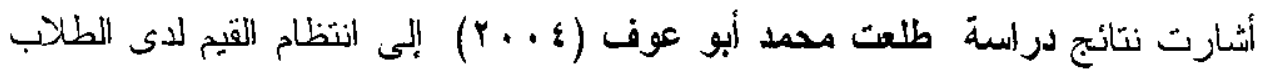

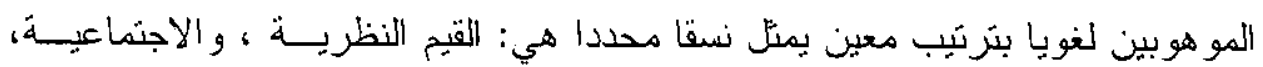

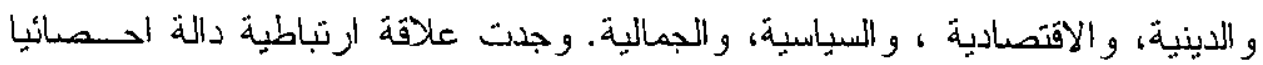

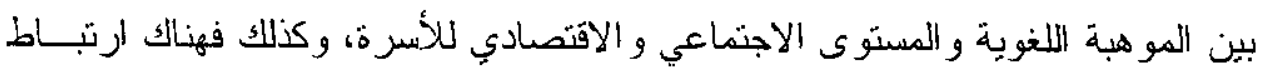

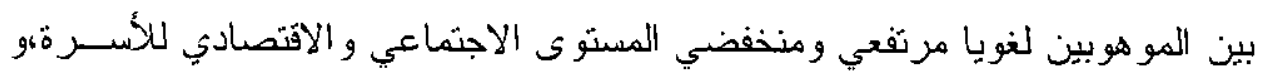

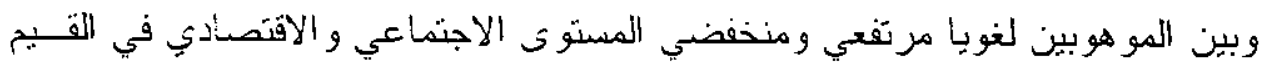

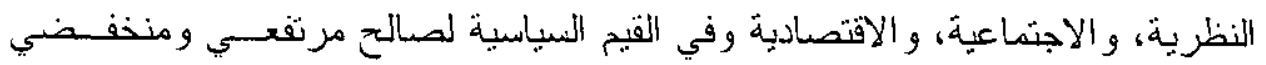

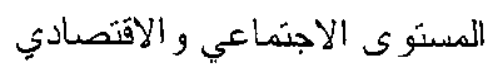

و استخدمت هلى مصطفى محمد وأسامة محمد عبد المجيد (ه . . r) العصف الأهنى فى تتمية الكتابة الإبداعية القصصية للطلابب المو هو بين لغويا ومهار ات ما ور راء الفهج

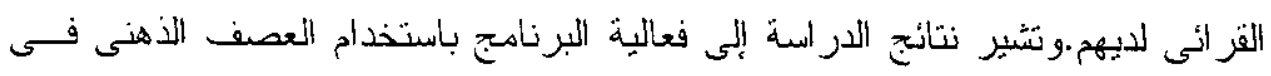
تتمبة الكتابة القصصية وفى تحسين مهار ات ما ور راء الفهخ.

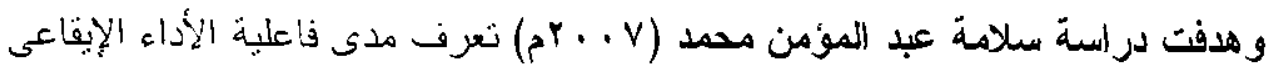

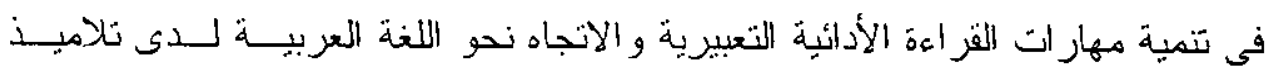




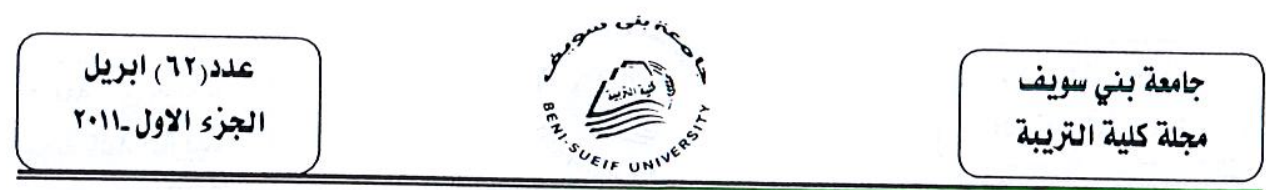

الصف الخامس الابتدائى، وشملت أدوات الدر اسة: قائمة مهـــار ات القـــــاءة الأدائبـــة

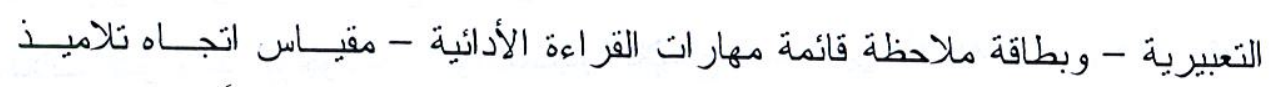

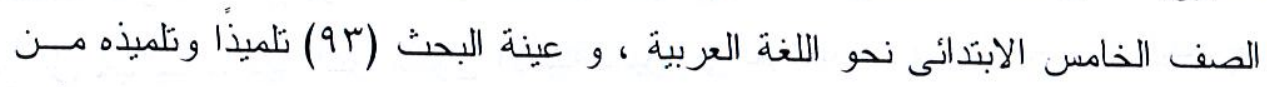

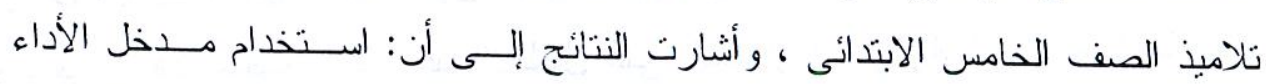

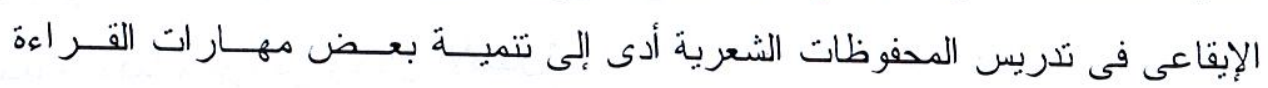
و الأدائبة التعبيرية والاتجاه نحو اللغنة العربية ومن خلال المقارنة بين الطلاب ثنائي اللغة في بر امج المو هوبين وطلاب ثنائي

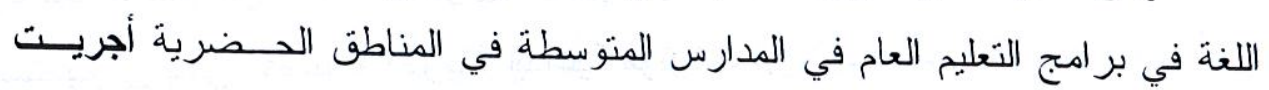
دراسة Brice, Alejandro (2008)، وتوصلت نتائج الدراسة إلى ميزة اللغة الثانوية

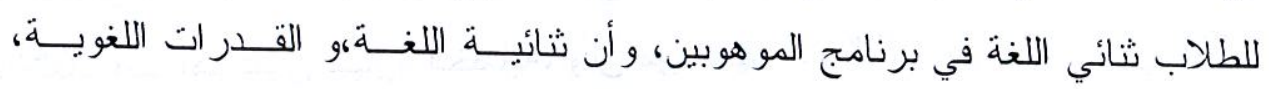

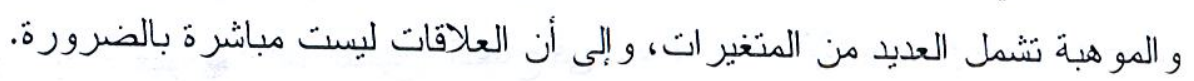

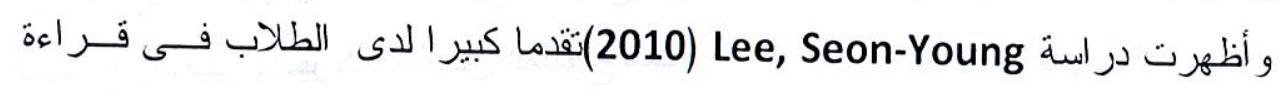

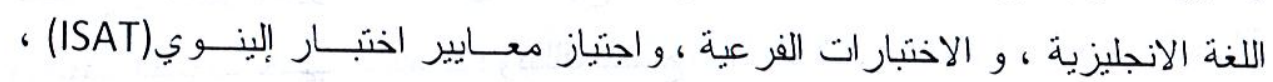
ومقاييس التقدم الأكاديمي (MAP) و كذلك تحسن توقعات الأبــاء لمـسـتوى الإنجــاز الأكاديمي للأبناء.

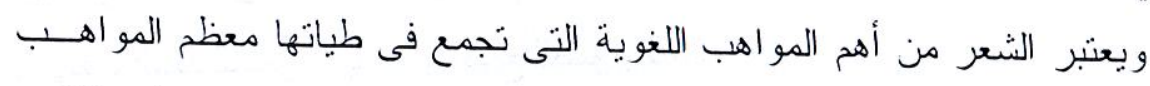

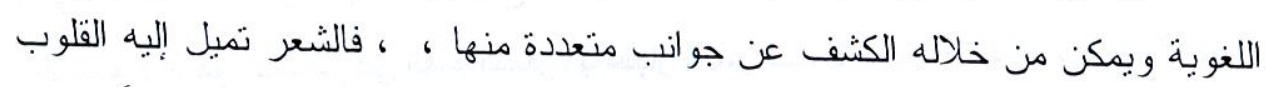

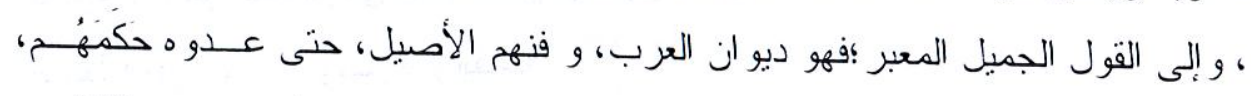

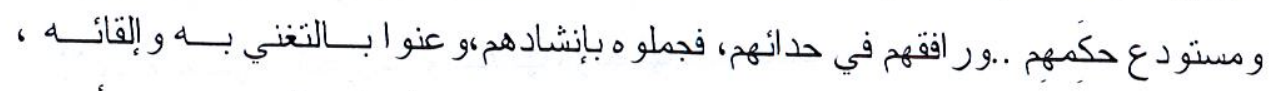

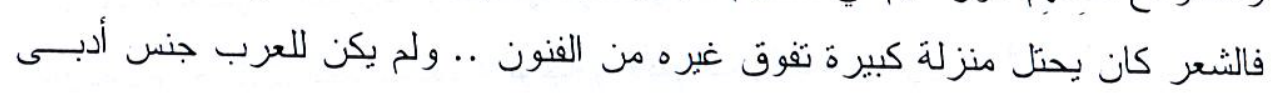

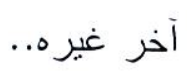

ويمتاز الشعر عن غيره من الفنون بأنه "أكثر قدرة على إيصال تجربة الفنــان

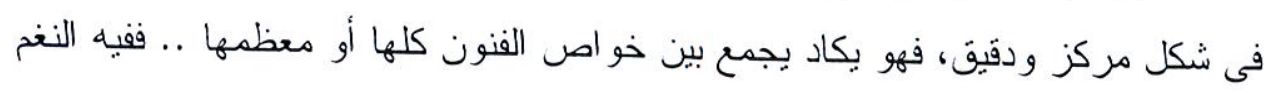




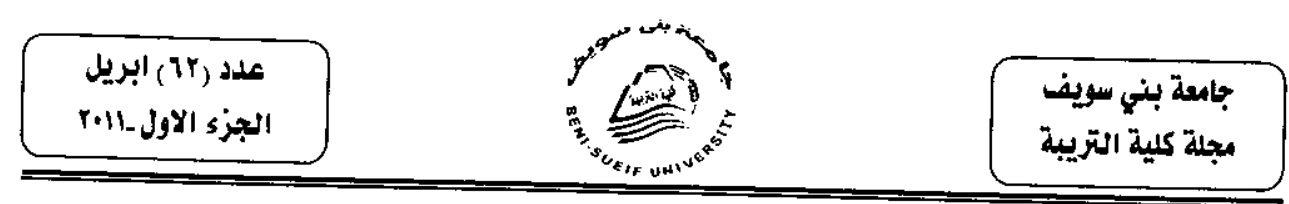

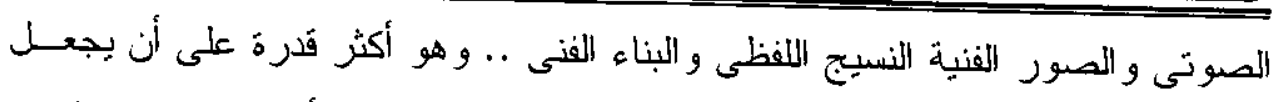

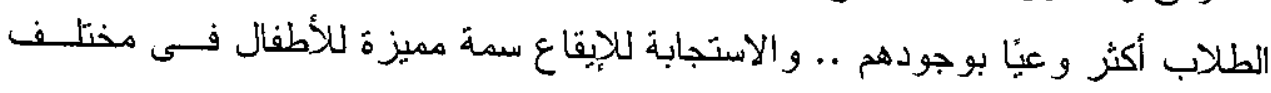

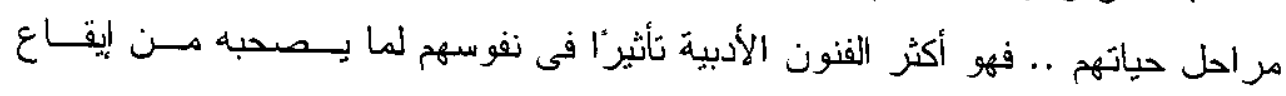

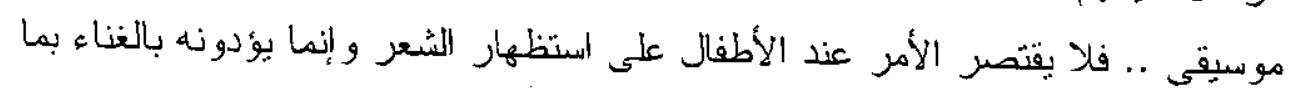

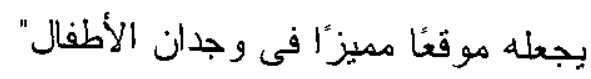

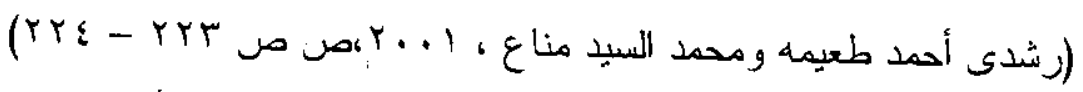

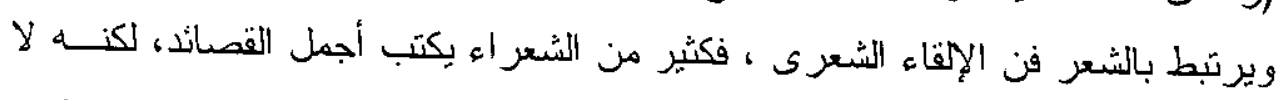

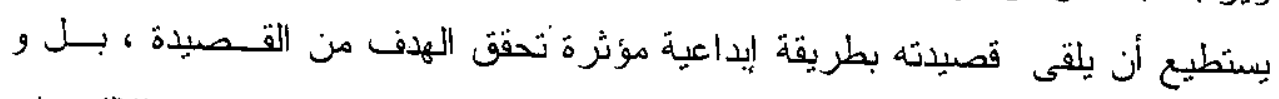

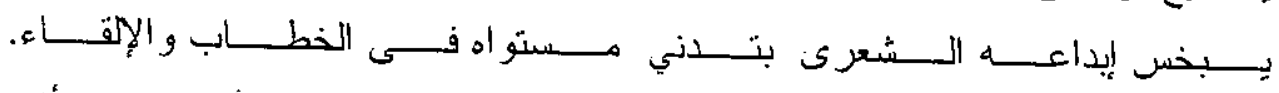

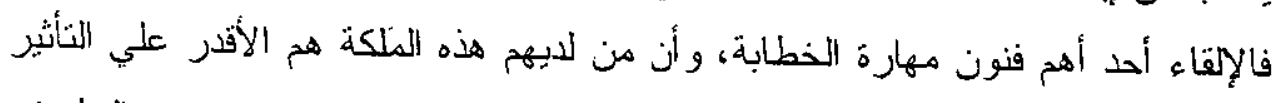

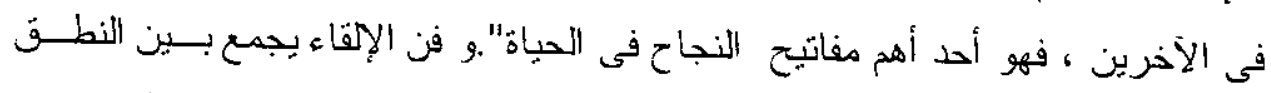

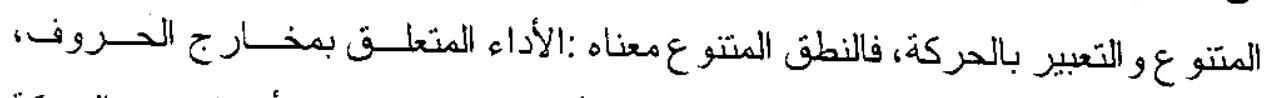

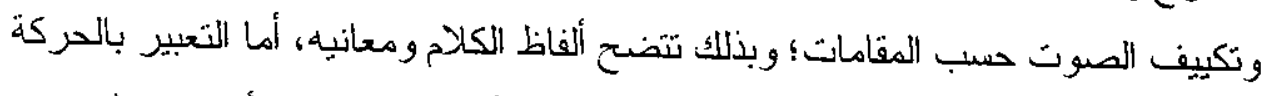

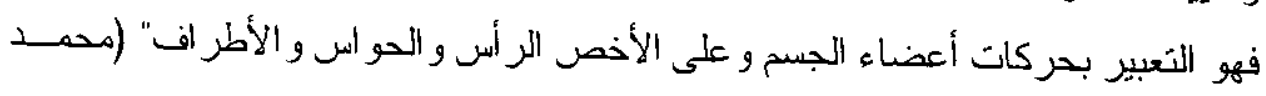

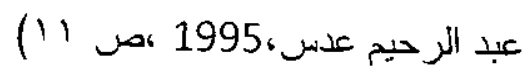

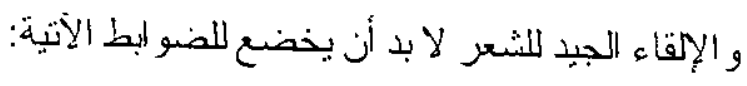
- التذوق؛؛ إذ هو الأساس في إلقاء الشعر ، باعتبار الشعر تنصهر داخله الأحاسيس و المشاعر.

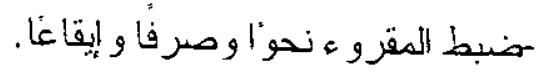

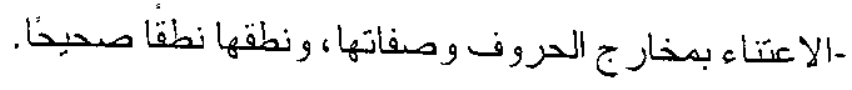

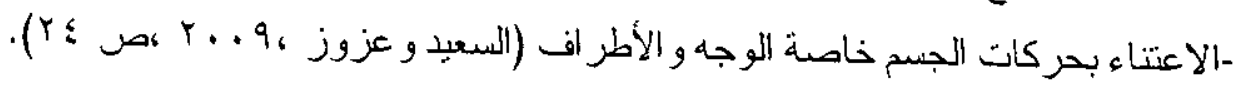




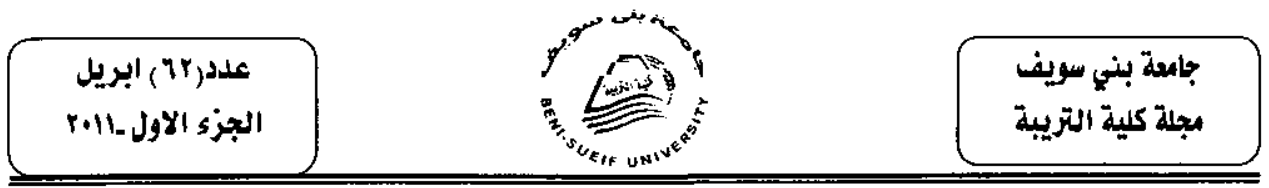

و الإلقاء الشعزى الجبد فى المبدان التعليمى يبسر على الطلانب الفهح و التحليل، وينمى

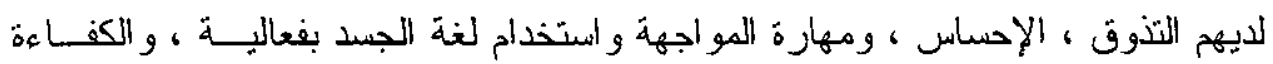
و النتأثير الإيجابيى فى الآخرين.

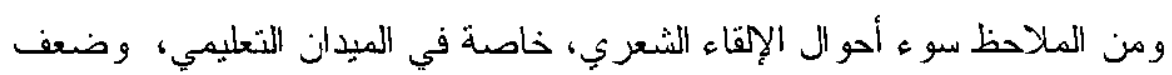

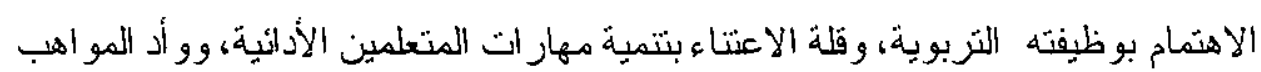
في مهدها؛ بغياب ر عايتها وصقلها.

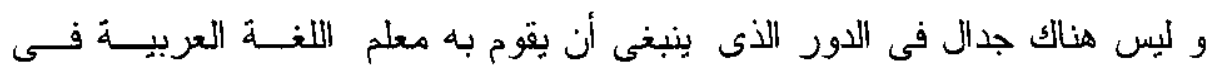

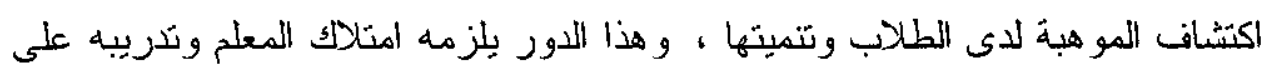

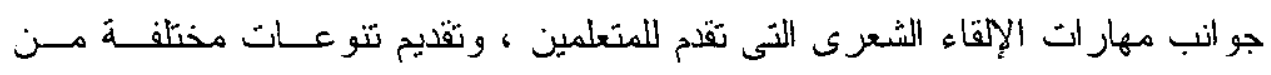

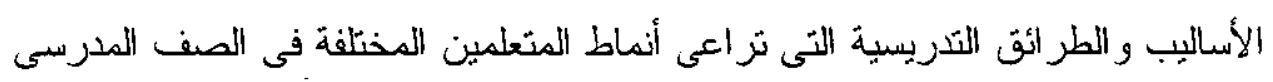

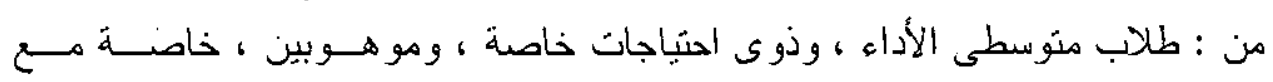

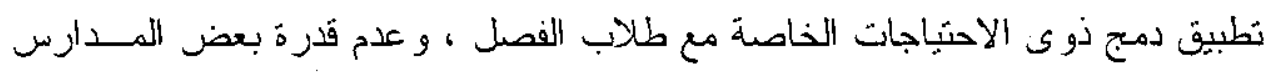
على توفير ، غرف مصادر التعلم اللمو هوبين.

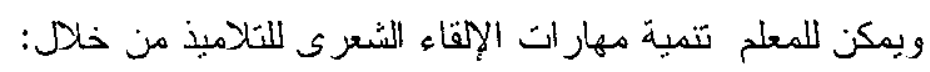
- - جذب المعلم للتنامبذ للشعر وأهمينه. - تببيه التتلاميذ إلى إز الة مركبات النقص التي نسيطر على فئة منهح .

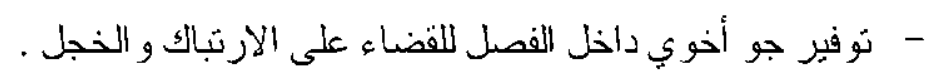

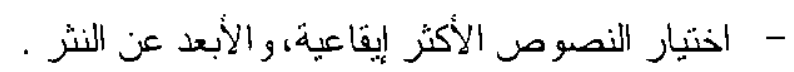
- تحليل مهارات الإلقاء الشعرى ، وتدريب المتعلمبن عليها.

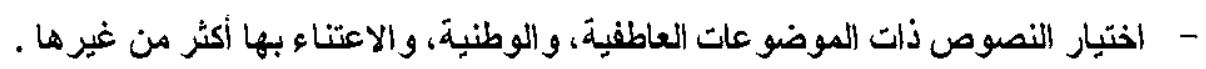

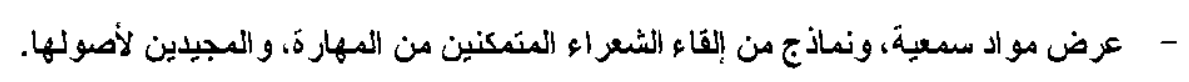

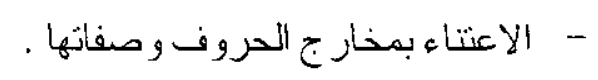
- - عرض قو ائم السير الذانية. - تتمية القدرة اللفظية ،و القدرة على القيادة. 


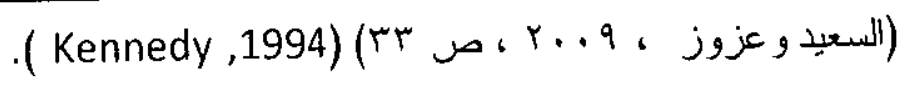

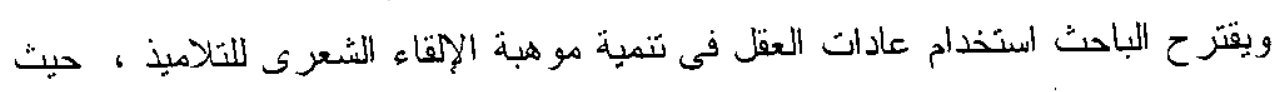

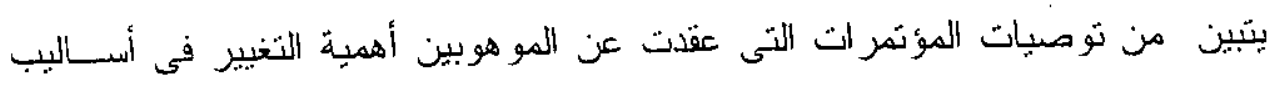

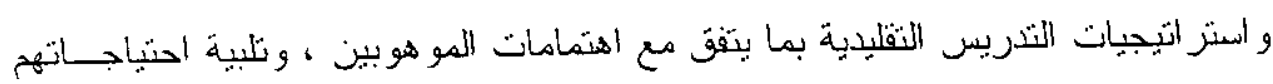

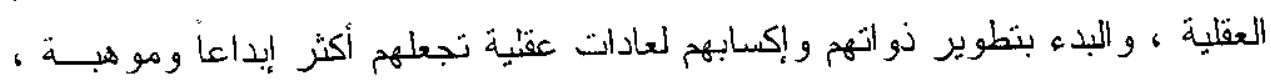

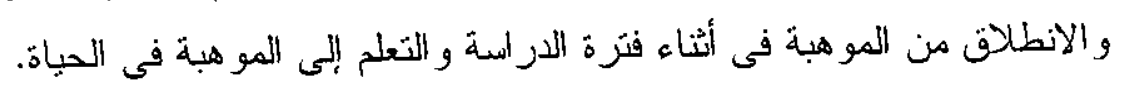

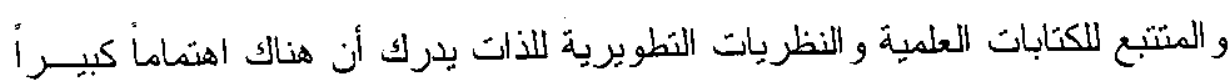

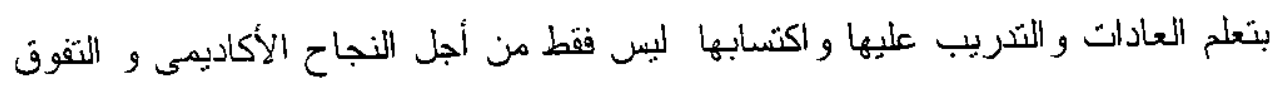

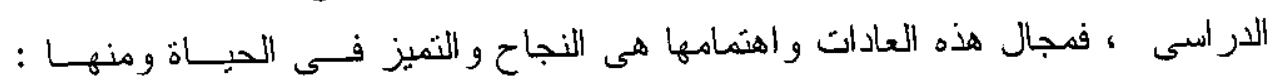

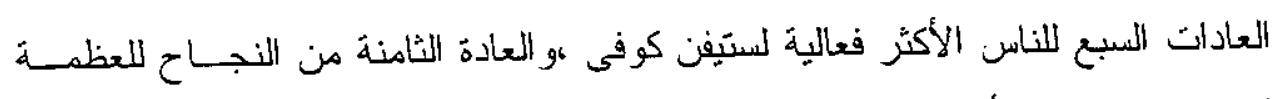

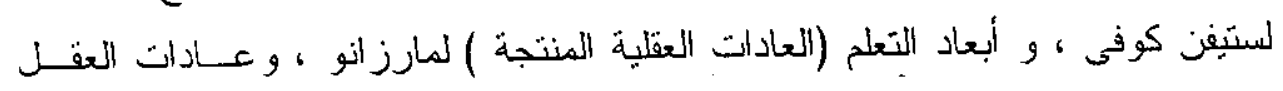

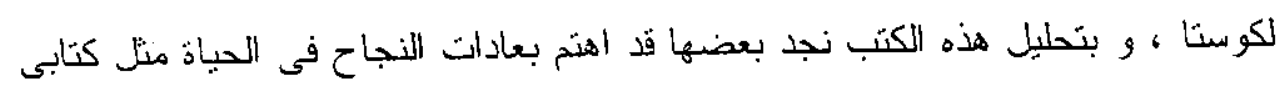

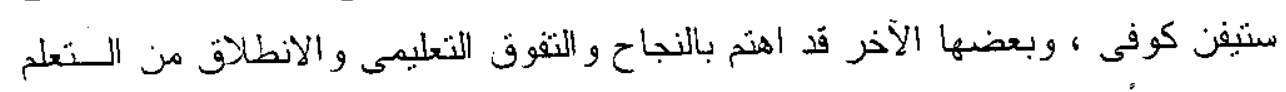

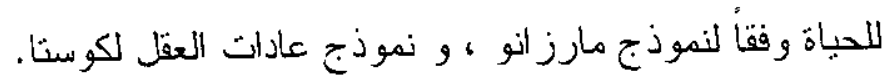

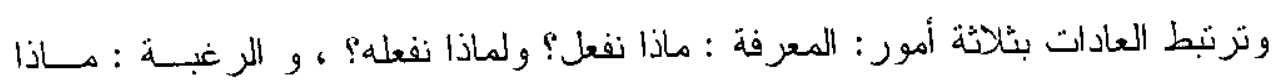

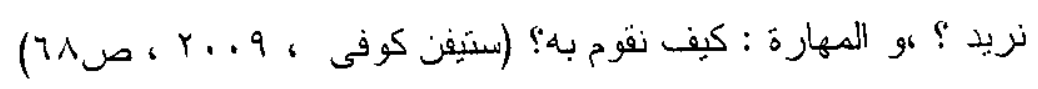

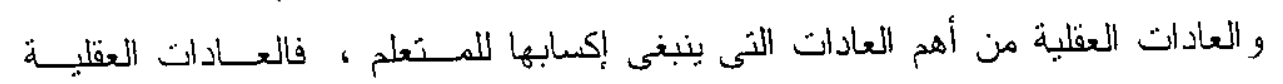

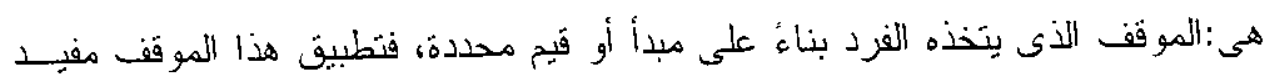

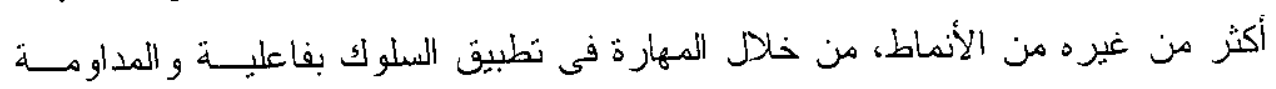

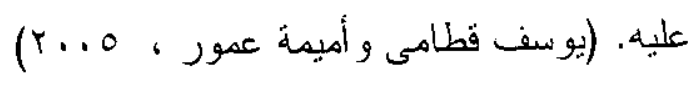
و هناك عدد من التصنيفات لعادات العقل منها: 


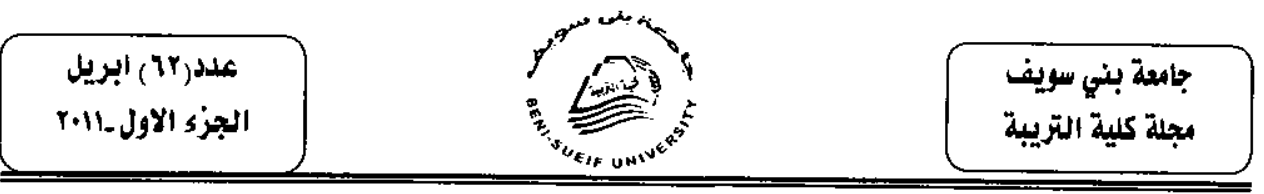

-تصنيف مارز انو وزملاؤه (991 (991) حيث صنف مكونات البعد الخـامس (العـادات العقلية المنتجة) إلى ثلاث مجمو عات وهى: التفكبر و التعلم على تنظيم الأات - التفكير الناقد - التفكير و التعلم الإبداعى.

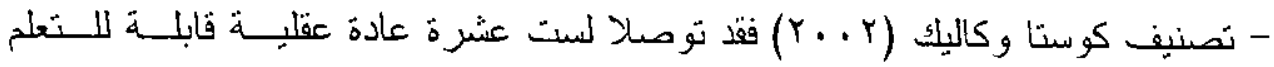
و التثريب فى كتاب: عادات العقل سلسلة نتموية .. و تمثلت عادات العقل فى :

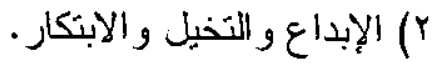

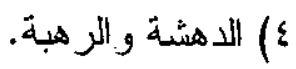

آ) القبام بالمخاطر ات المحسو بة.

$$
\begin{aligned}
& \text { ^) البحث عن الدعابة }
\end{aligned}
$$

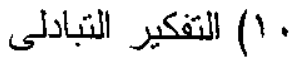

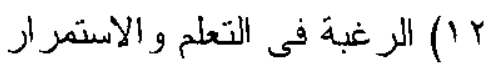

$$
\text { ك أ) الكفاح من أجل الدقة }
$$

$$
\begin{aligned}
& \text { (1) عادة المثابرة } \\
& \text { ( ) الاستماع بتفهم و بالتهور } \\
& \text { V) التساؤل وطر ح المشكلات } \\
& \text { 9) جمع البيانات بكل الحو اس } \\
& \text { (1) التفكير بمرونة } \\
& \text { rا }
\end{aligned}
$$

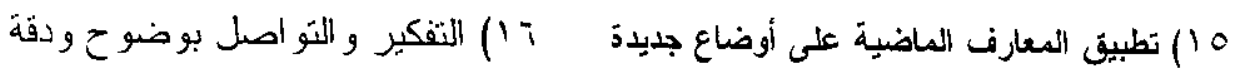

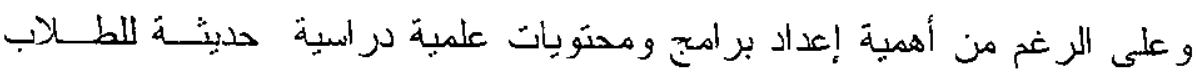
فالأهمية الأكبر فى استخدام الأدوات و الأساليب التنى تفى بتلك البر امتج و المحتو يات

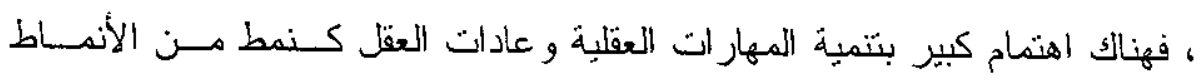
الحديثة للارتقاء بالمتعلمبن خاصة مع التجديدات التزبوبة و الارثقاء من ثقافة الحفظ ولئه

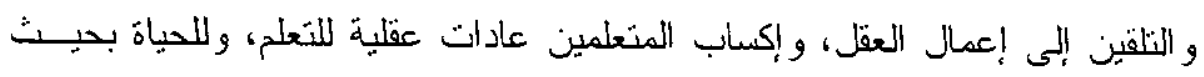

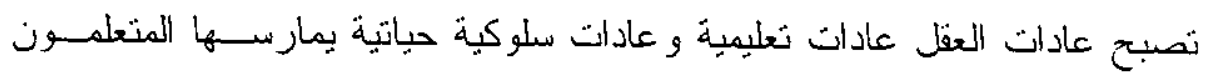
بصفة يومية مستمرة. إضافة إلى تخطى فكرة اجنباز الطلاب للمر احل اللدر السـية

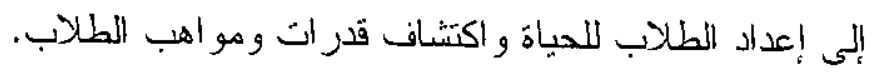
ونم تضمين العادات العقلية في برنامج كامل للمدرسة على نطاق و اسع في العديـــ

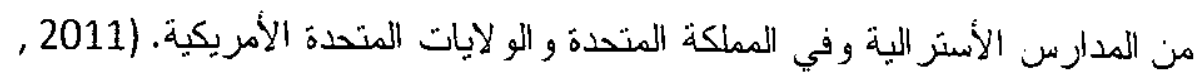

(Burgess, Jill 


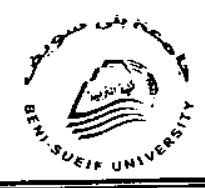

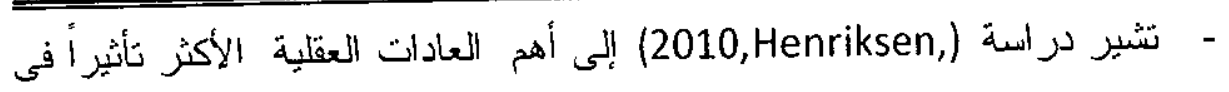

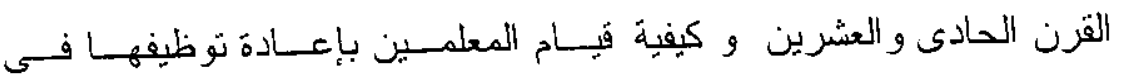

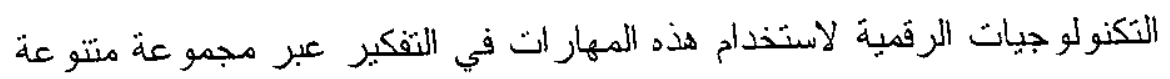
من الموضو عات. - العادات العقلية عادات أصيلة موجودة بين الطلاب المتقوقين ونوجد فروف بين مستوى العادات العقلية بين الطلغب (سميلة الصباغ و آخرون، آ . . ب).

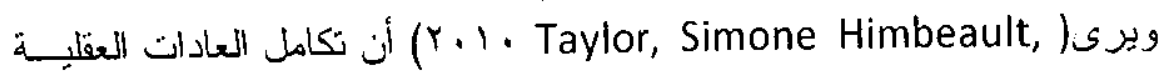

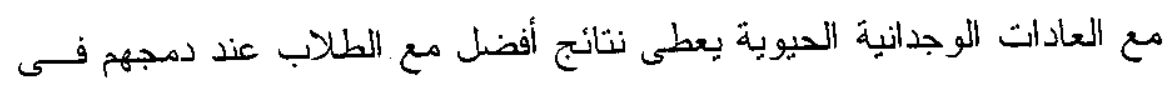
بيئة تعليمية و احدة و لإعداد الطلاب لرحلتهم كما المتعلمين مدى الحياة. ويحدد (Goldenberg, E. Paul,2010) من خلا ثلاثت در اسات عن عادات

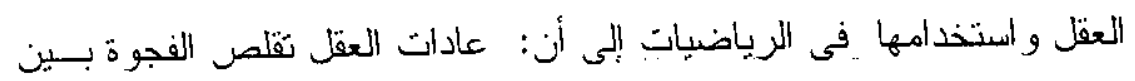

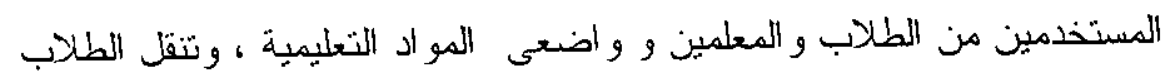

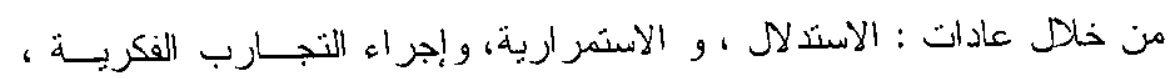

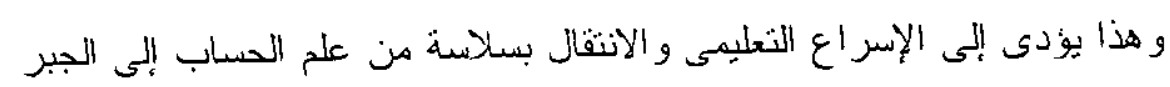

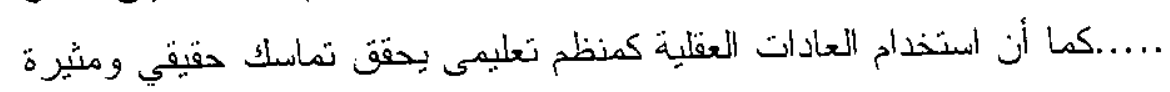
للدهة في كثير من الأحبان إلى المناهج الددر استي . كما أن :

- تتمبة العادات الإنتاجية للعقل نعتبر أهدافاً نعليمية يمكن تحقيقها من خلا أبــة

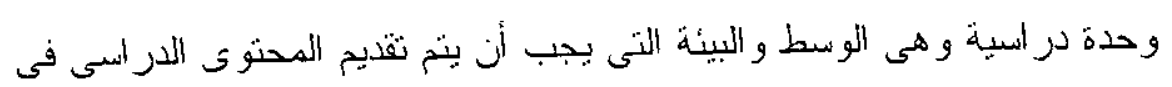

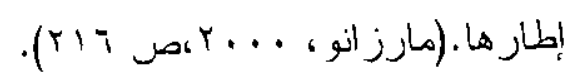
- إهمال استخدام العادات العقلية بسبب فصور أ شدبدأ فى نتائج العملية التعليمية،

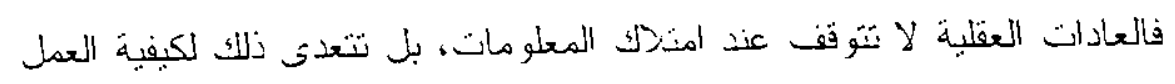
عليها و استخدامها فى الحباة. (Costa, 2001). 


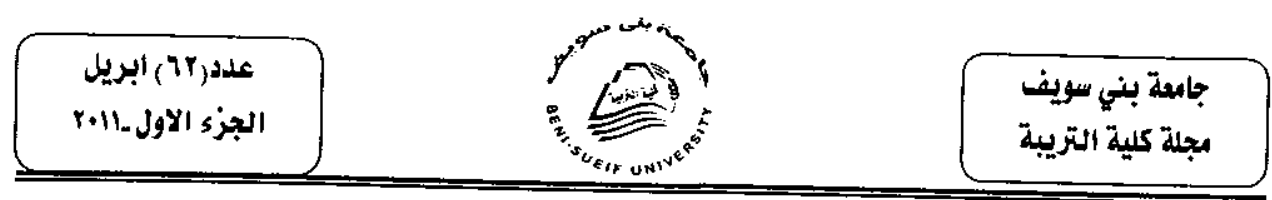

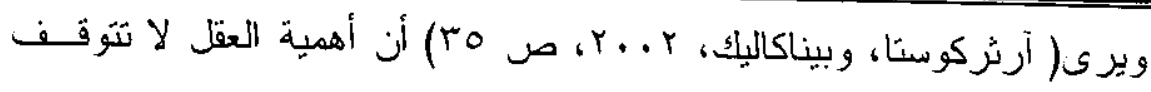

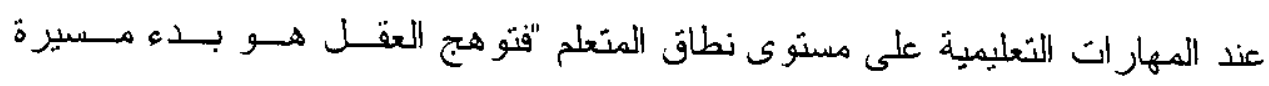

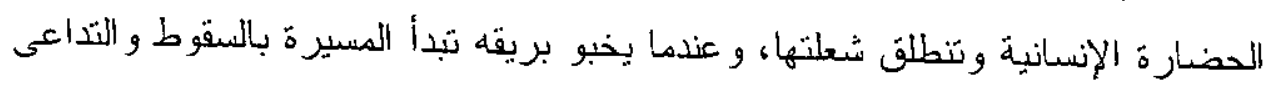

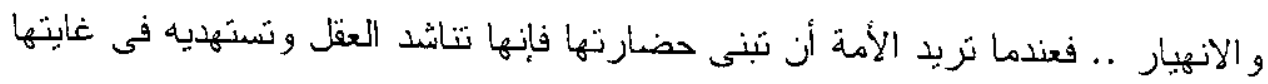

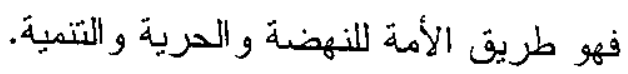

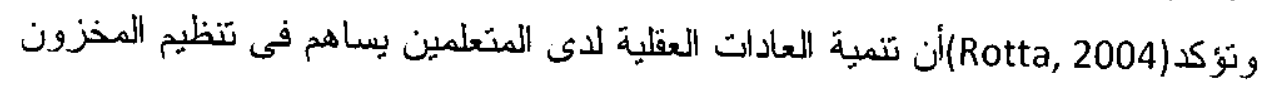

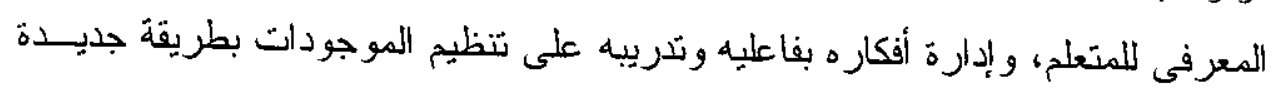

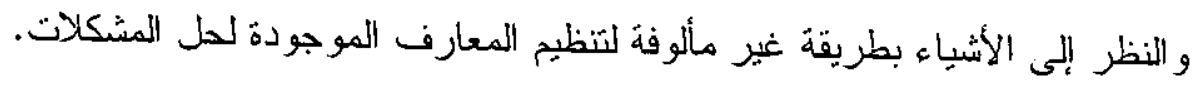

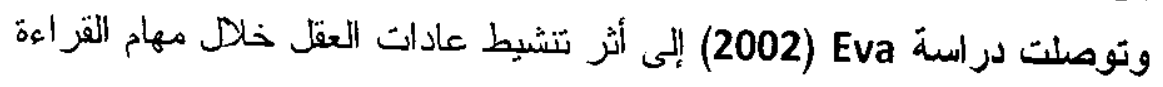

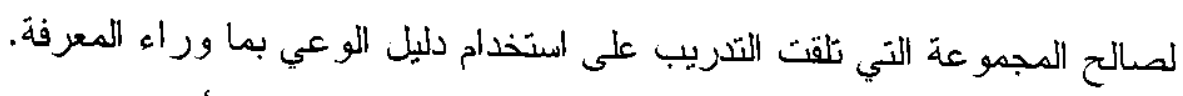

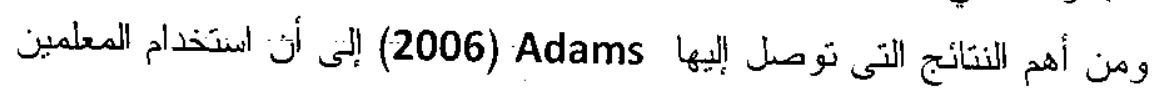

اللعروض التقديمية أدى إلى تتمية عادات العقل لدى المتعلمين.

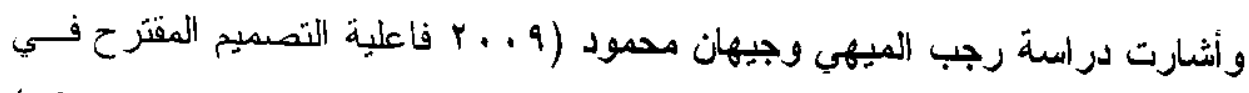

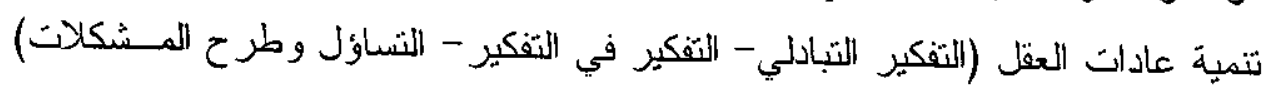
و التحصيل الدراسي للطالبات.

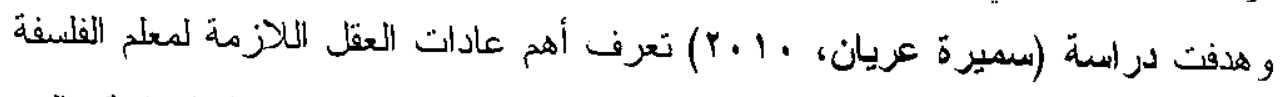

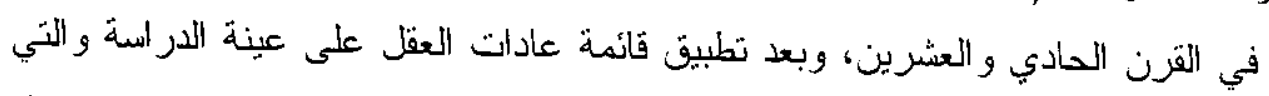

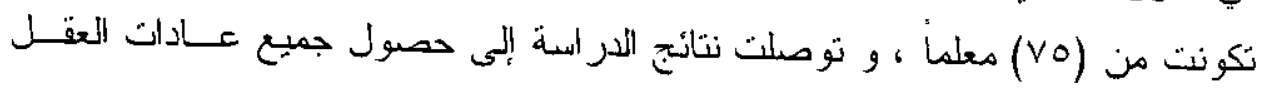

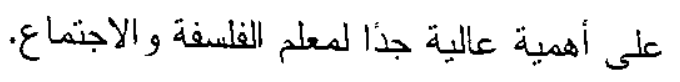

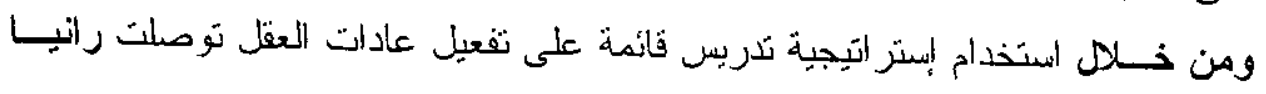

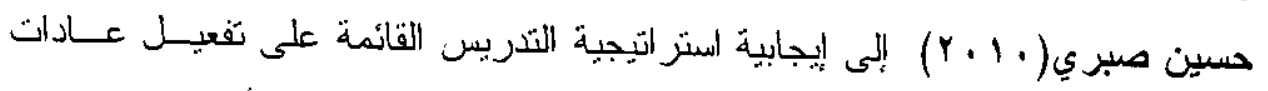

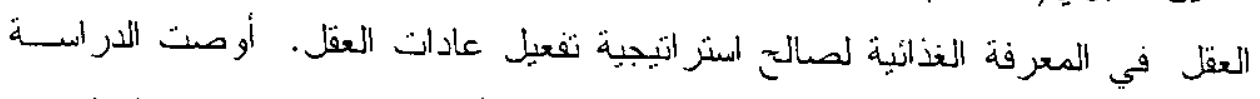

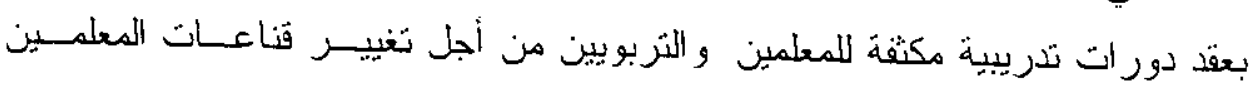


و تشجبعهم على استخدام الستر التيجية عادات العقل، وتضمين مناهج التفكيـر و وعـادات العقل في المساقات التي تكرس لطلبة التربية،ور كذلك ضرورة تبنتي المــدارس لفكـرة تنمية ونظوير عادات العقل لاى طلابها .

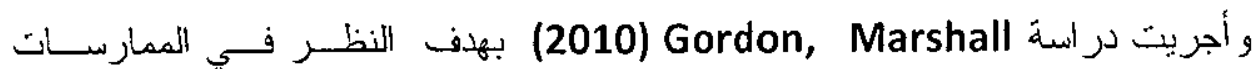
الإنتاجية للعقل رباضياءمن خلا محادثات ومناقششات الفصل الدر استسى و مناقـشة

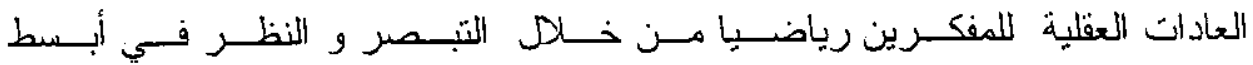
المشكلاث، التجمبع و تفكيك الأشياء

و هدفت دراسة Hew, Khe Foon (2010) الدر الهة إلى بحث في العادات العقليــة

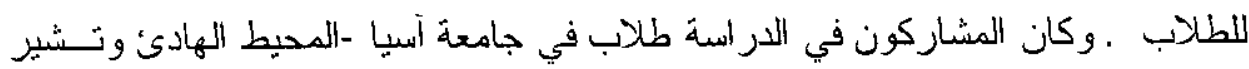

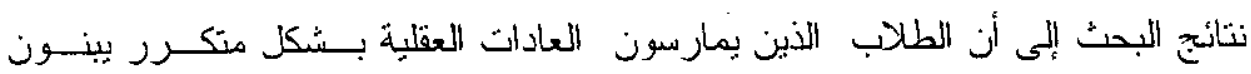
معرفنهم الذانية بشكل أفضل.

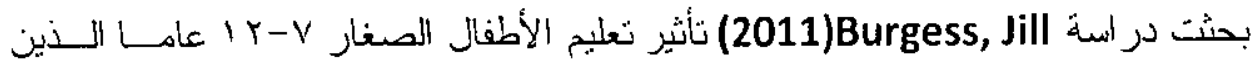

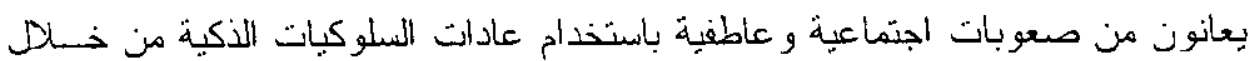

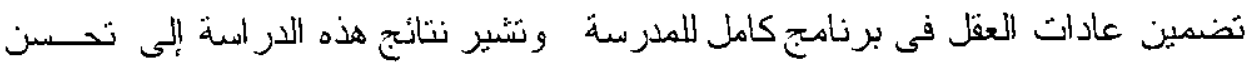
عام فى عادات العقل ، مع انخفاض عام في المشكلات السلوكية، ونمو التفكير بمرونة. وبالتالى يمكن نوظيف العادات العقلية فى الارتقاء بجو انب المو هبة لدى المو هو بين

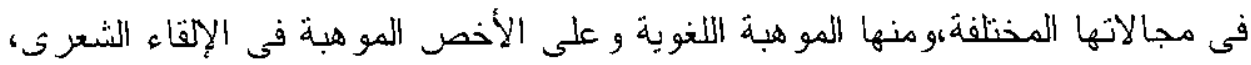
حبث يرتبط نموذج عادات العقل بتمية مو هبة الإلقاء الشعرى من عدة جو انب:

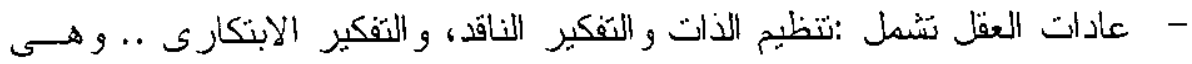
تزتبط بالمو هوبيز على نحو مباشر ، فمو هبة الإلقاء الشعرى تحتاج تتظبمياً ذانياً من المتعلم لكيفية الإلقاء و الانتقال من جزئية لأخرى، و التقكير الناقد بــضيف

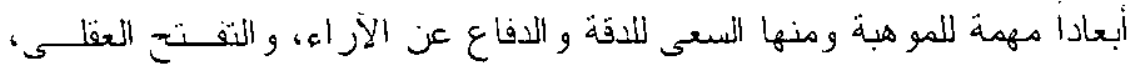

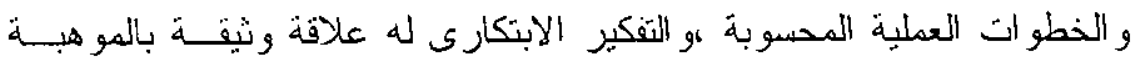




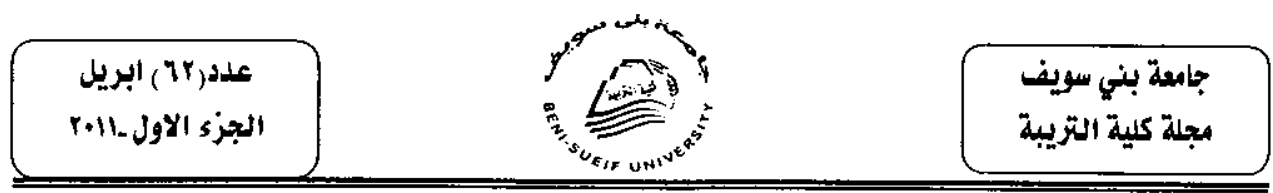

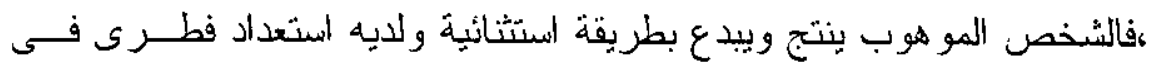
المجالات العقلية و الإبداعية، ومنتجات المو هوب ثتسم من خلا بل تحليل جو انبها

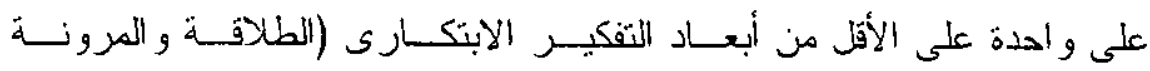
و الأصالة، و الحساسية للمشكلات، القدرة على إضى الضئة التفصيلات).

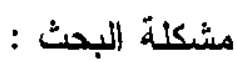
تتمثل مشكلة البحث في نراجع الاهتمام بمجال المو هبة و المو هو بين من حيث اكتشافهم

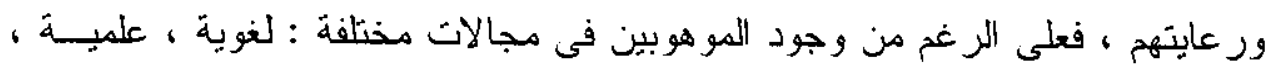

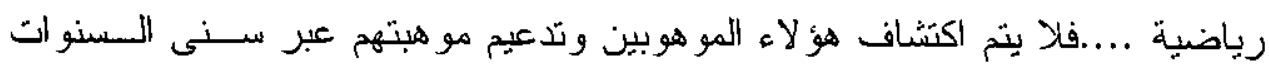

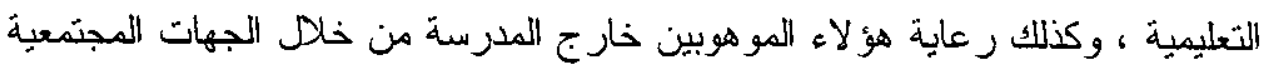

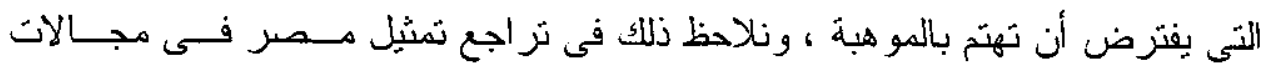

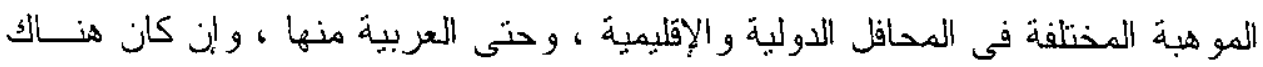

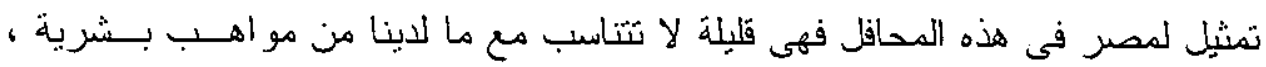
و هذا بلقى بالمسئولية على وزارة التزبية و التعليم لاكتشاف هؤلاء المو هو بين ور عايتهم. و البحث الحالى يهثت بمو هبة الإلقاء الشعرى لدى تلاميذ المرحلة الابتدائية.

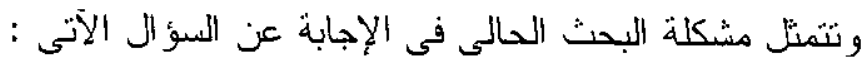

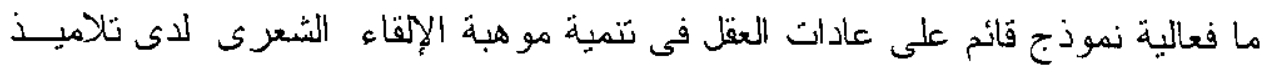
الصف الخامس الابتًائى وتتمبة الو عى بالمو هبة لديهم ولدى معلمى اللغنة العربية ؟

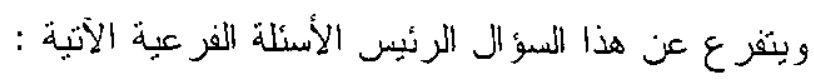

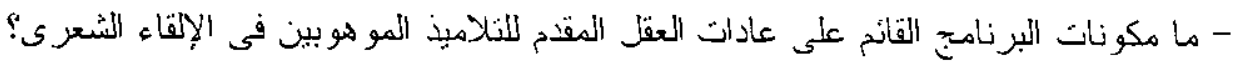

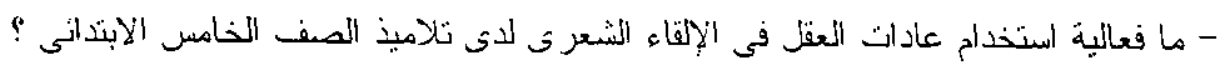

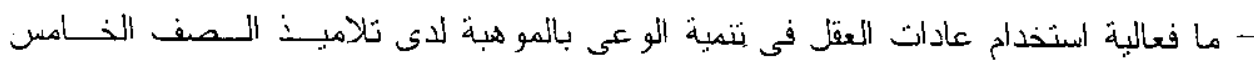

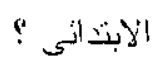

- ما فعالية امتخدام عادات العقل فى الإلقاء الشعر ث لأث معلمى اللغة العربية ؛؛

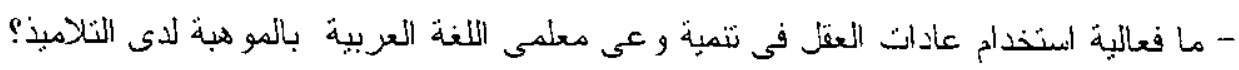


- بعد هذا البحث من البحوث القلية المتى اهنمث بمو هبة الإلقاء الشعرى.

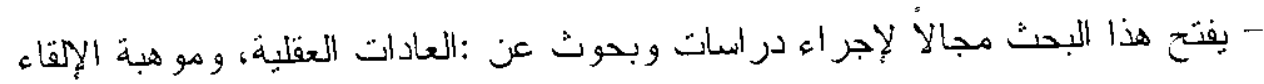

$$
\text { •الشعرى، و الو عى بالمو هبة. }
$$

- حيث بساعدهم فى اكتشاف مواهبهم المختلفة خاصة موهبة الإلقاء الشُعرى للدى الطلاب.

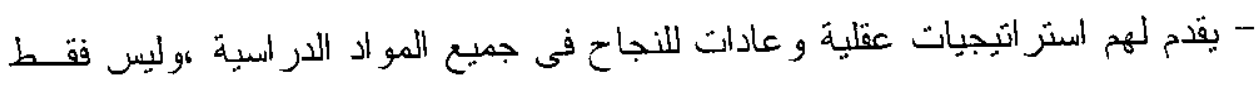
في مو هبة الإلقاء الشعرى فقط.

$$
\text { حبث: بساعدهم فى - المعلمون: }
$$

- تطبيق نموذج للعادات العقلية فى النجاح بصفة عامة مما بمكنهم من الاسثفادة به. - يساعد المعلمين على تحديد مستوى أداء الطلخب فى الأداء و الإلقاء الشتعرى. - بساعد المعلميز على نحديد مسثوى أدائهج فى الإلقاء الشعرى.

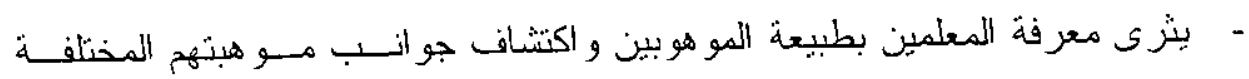
،و ثقديم بر امج لنتمبة المو هبة لدى الطلانب، ور عاية هؤ لاء المو هو بين...

$$
\text { - الموجهون: }
$$

$$
\text { حبيث بو جه أنظار هم إلىى: }
$$

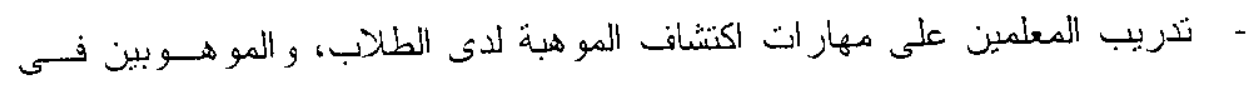

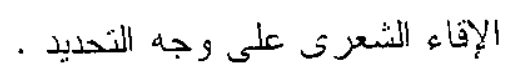

- تذريب المعلمين على الاستر اتيجيات القائمة على العادات العقلية و نطوبر الذات . 


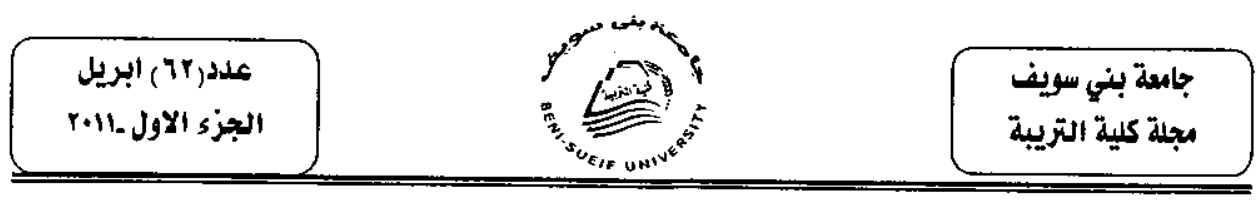

צ - مخططو و و اضعو المناهج:

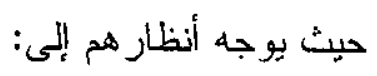

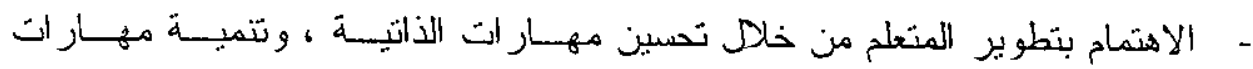

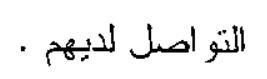

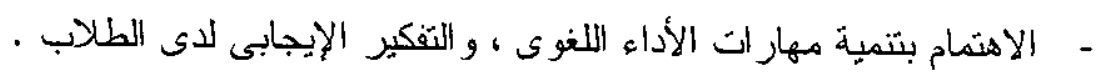

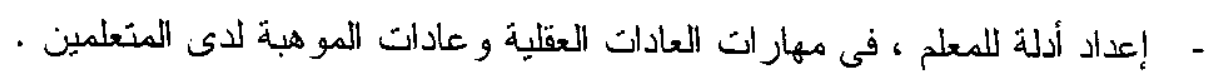

$$
\text { - - الباحثون: - }
$$

- يفتح هذا البحث مجالأ للدر اسات و البحوث في هذه النو عية النى تهـتخ بالعـادات

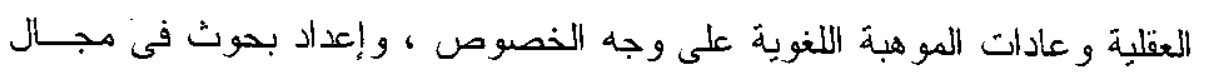

$$
\begin{aligned}
& \text { المو هبة قائمة على أحد العادات العقلية . } \\
& \text { مينهج البحث: هبه }
\end{aligned}
$$

بستخدم البحث الحالى المنهج الوصفى فى تتاول ما ينصل بموضو ع البحث من أدبيات

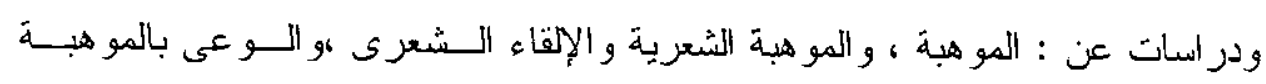

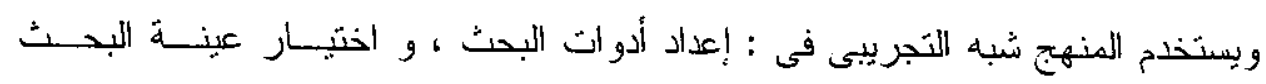

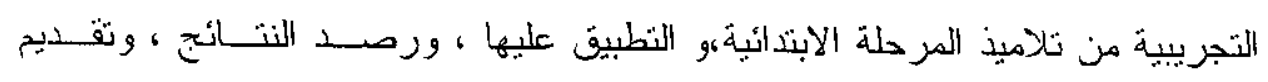

$$
\text { التوصبات. }
$$

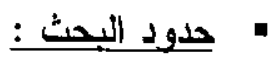

- حدود مكانبة :طبث البحث على عينة من نلاميذ ومعلمى المــــارس الابتدائبــة

$$
\text { بمحافظة الشرقية. }
$$

- - حدود بشرية :تلامبذ الصف الخامس الابتدائى الذين لديهز موهبة الإلقاء الشعرى

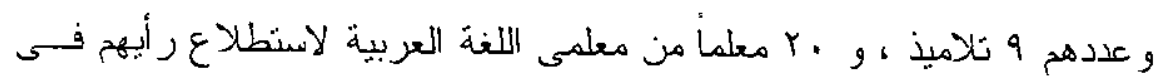

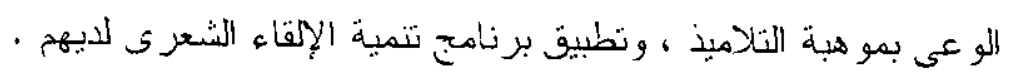

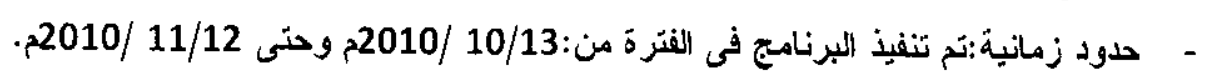




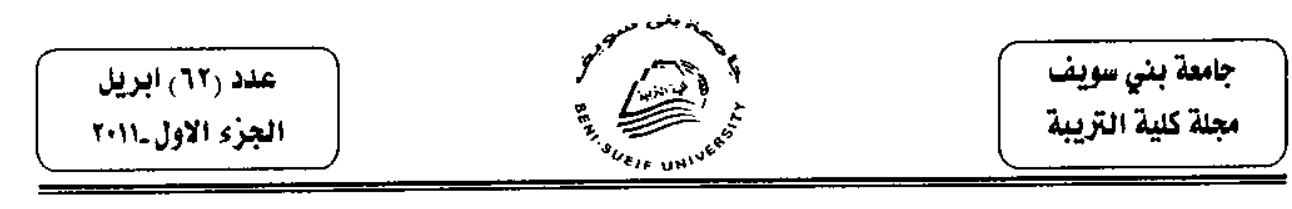

\section{خطوات اليحث:}

- الإطلاع على الأدبيات المتصلة بالبحث و الار السات السابقة.

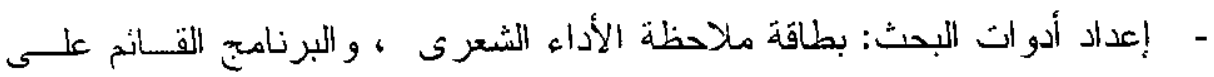

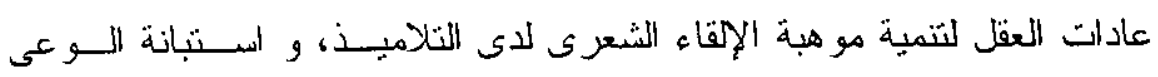

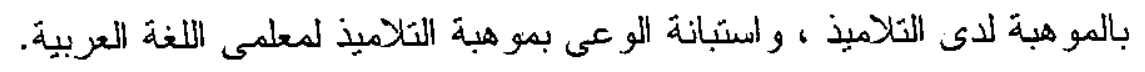
- التحكيم على أدو ات البحث ل

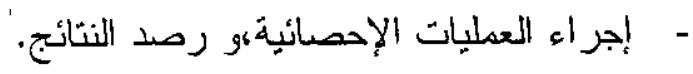

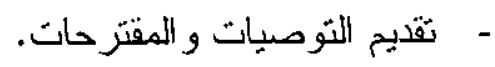
• مصطلحات البحث: :Habit العادة •

العادة : يعرثّ معجم مصطلحات الطب النفسى العادة بأنها فعل متكــرر - و التعــود والاعثباد فيقع فى نطاق در اسات التعلم فى علم النفس و هنه تكوين العادة ، و العـاداد

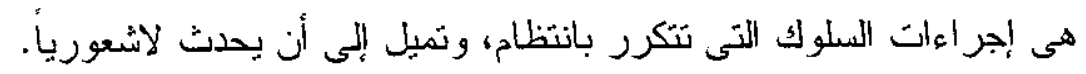
ويعرف (Perkins, 2001, 8) العادات العقلية بأنها نمط من السلوكيات الأكبة النية

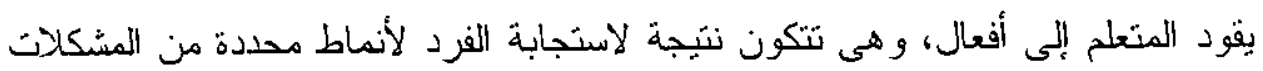

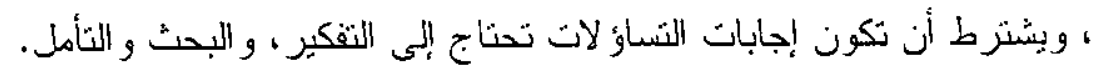

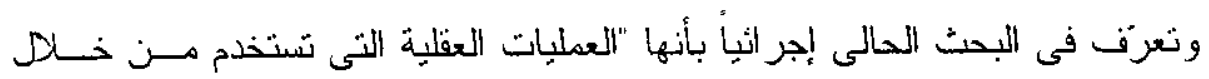

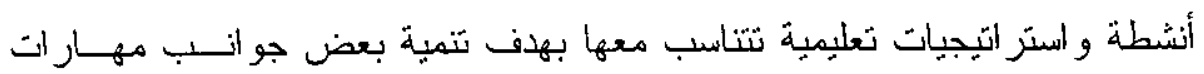

$$
\text { الإلقاء الشعرى لدى تلاميذ الصف الخامس الابثدائى. }
$$

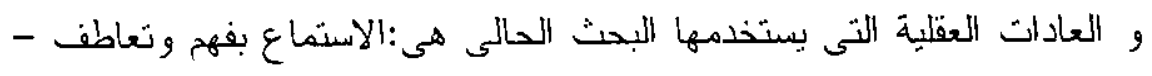

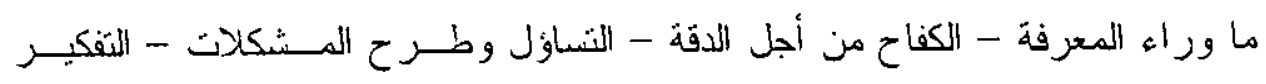




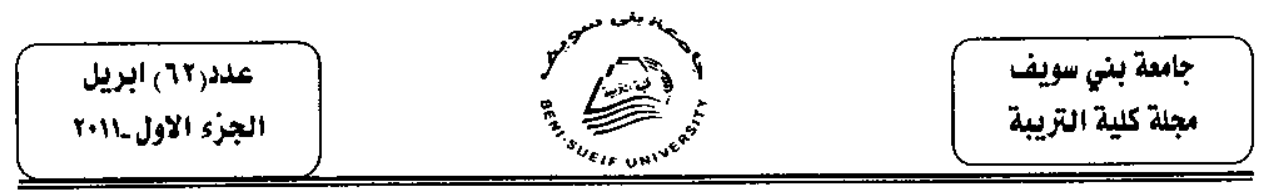

و التو اصل بوضوح - استخدام كافة الحو اس فى تجميع البيانات، البحث عن الدعابـة، و التفكير التبادلى.

\section{Giftedness الموهبة}

قدرة فطربة أو أستعداد موروث فى مجال واحد أو أكثر من مجالات الاستعداد

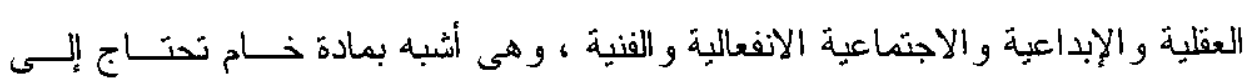

اكتشاف وصقل؛ حتى بمكن أن تبلغ أقصى مدى لها. المو هوب Gifted

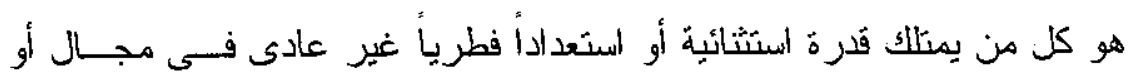

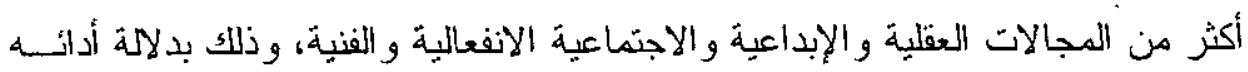

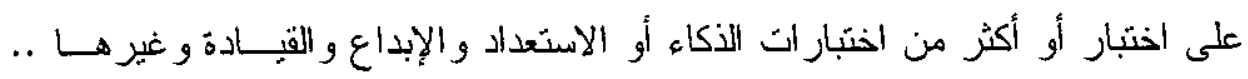

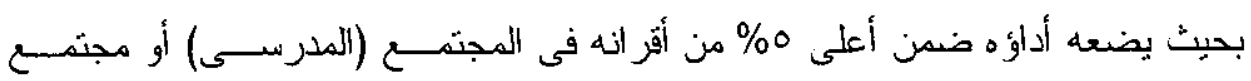

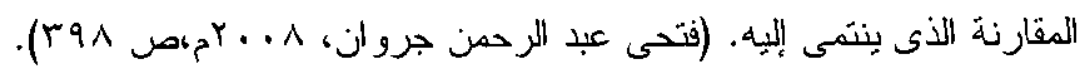

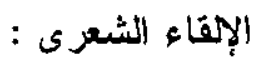
الإلقاء:

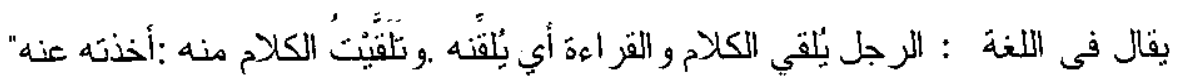

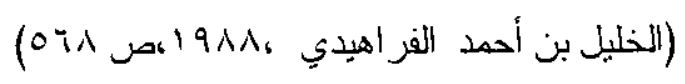

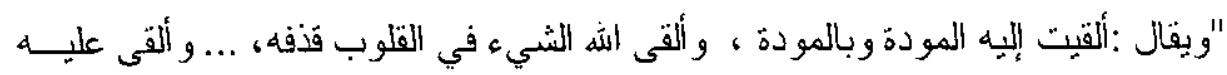

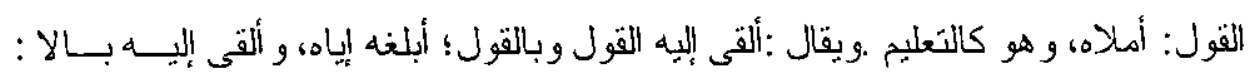

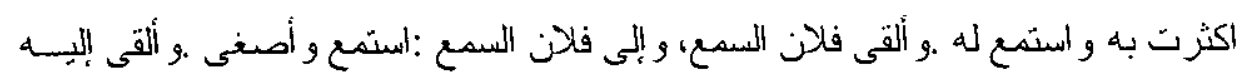

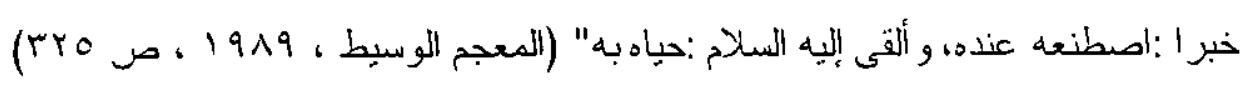

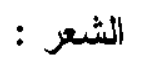

يقول الزمخشر ي: شعرت به :ما فطنت له وما تعلمته،وو هو ذكي المشاعر و هي الحواس "..

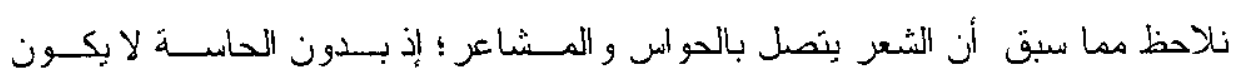
شعر ا،كما أن الشاعر إنما سمي بذلك لكونه بفطن أو يشعر بأشياء قد تغيب عن الآخرين. 


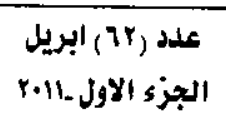

و يختلف الشعر اصطلاحأ قديماً ، و حديثًا :

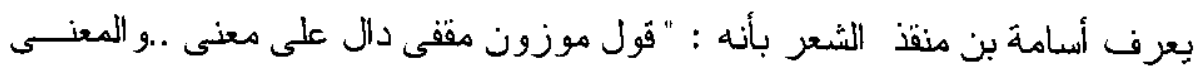

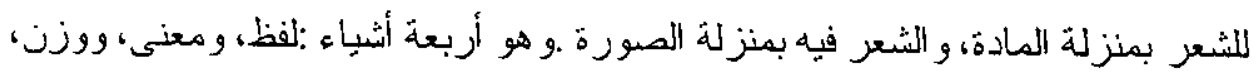

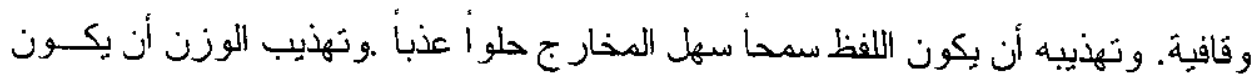

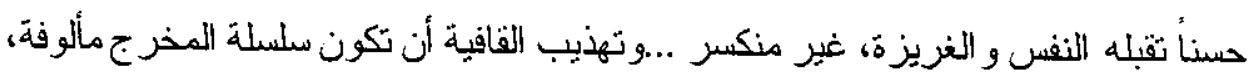
فإن القو افي حو افر الشعر"

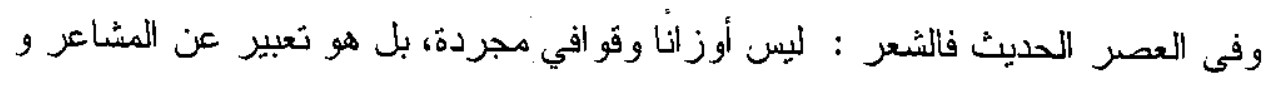
معاناة إنسانية تثوفًر فيها الفكرة و العبارة و الصورة و'الانفعال و.الإيقاع.

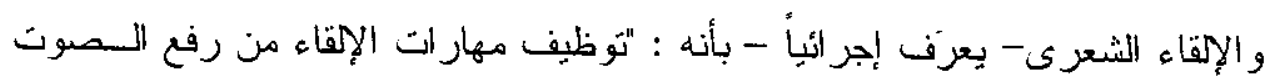
و استخدام الإشار ات و الإيماءات ...مع مر اعاة خصائص الشعر من الوقوف عند نهائية

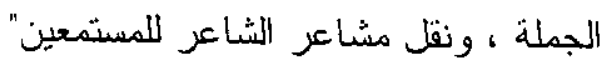

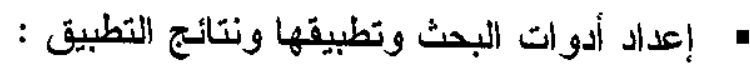

$$
\begin{aligned}
& \text { إعداد أدو ات البحث و تطبيقها: } \\
& \text { إعداد أدو ات البحث: وشملت أدو ات البحث: } \\
& \text { (Y) مائمة مهار ات الإلقاء الشعرى. }
\end{aligned}
$$

r) بطاقة ملاحظة لأداء التلاميذ فى مهار ات الإلقاء الشعرى (أدو ات قياس).

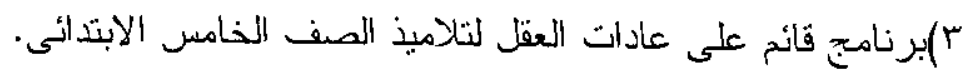
؛) برنامج قائم على عادات العقل لتتمية الإلقاء الشعرى لدى معلى ماتمى اللغة العربية.

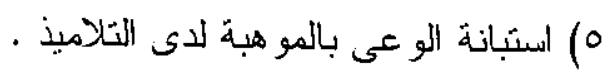

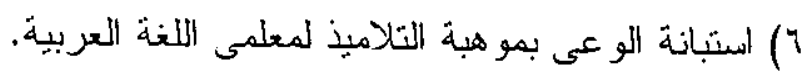

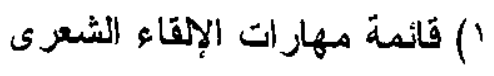

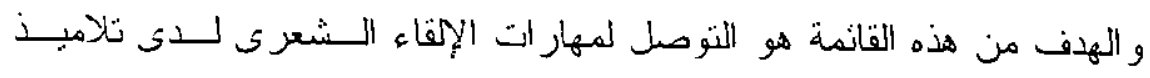
الصف الخامس الابتدائى وشملت القائمة فى البداية على المهار ات الآتية: 


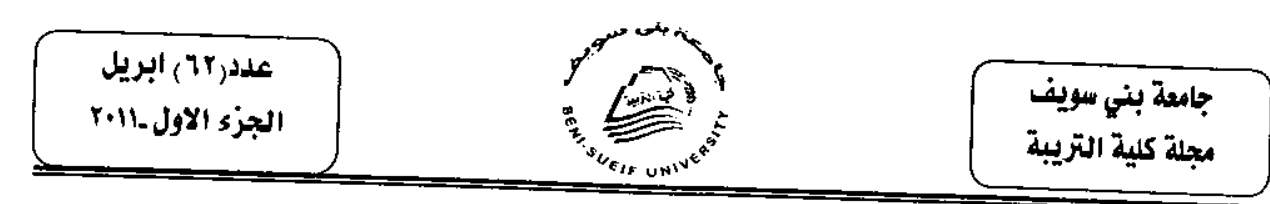

$$
\begin{aligned}
& \text { - . يلقى الشعر بصوت و اضح } \\
& \text { - - يستخدم الإيماءات و الإرشادات } \\
& \text { - يوز ع النظرات على الحاضرين }
\end{aligned}
$$

- يرفع صوته و يخفضه نبعأ للكلمات و المو اقف الشتعرية -

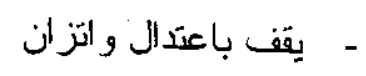

- - بينهى الإلقاء الشعرى بطريقة مناسبة ونية -

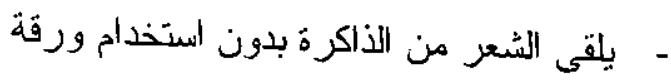

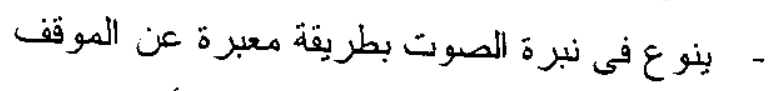

$$
\text { - - يقاعى القافية و الكلمات الأخيرة فى الأبيات }
$$

$$
\text { - مالقى الشعر بحماسة. }
$$

وتم عرض قائمة مهار ات الإلقاء الشُعرى على مجموعة من المحكمين لإباء الرأى فى:

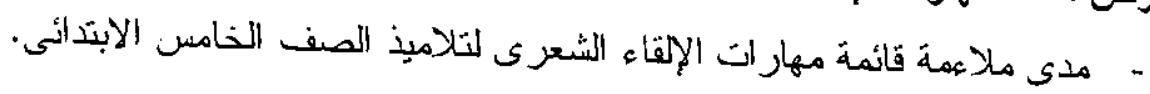

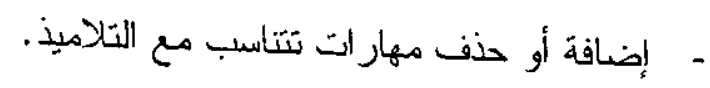

$$
\text { وتمثلت آر اء المحكمين فى: }
$$

- الاكتفاء بعشر مهار ات من مهار ات الإلقاء الشعرى.

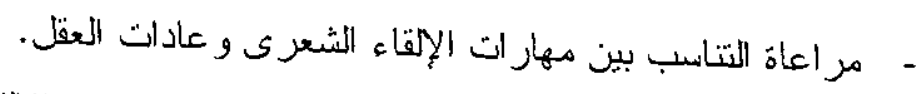

وفى ضو ء آر اء السادة المحكمين نم المتوصل لقائمة نهائية بمهار ات الإلقاء الشعرى.

إعداد بطاقة الملاحظة: 


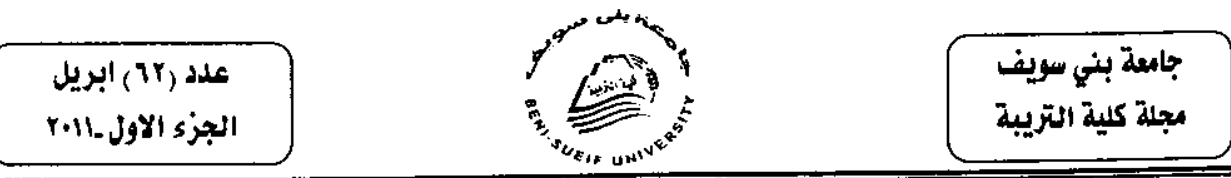

وفى ضوء قائمة مهار ات الإلقاء الشعرى وفى ضوء آراء اللسادة المحكمين، ثن

التوصل لبطاقة الملاحظة الآتبة:

\begin{tabular}{|c|c|c|c|}
\hline غ غير موجودز & 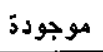 & المهار3 & s \\
\hline & & بلقى الشُعر بصوت و اضح & 1 \\
\hline & & بستخدم الإيعاءات والإرشُادات & $r$ \\
\hline & & يوزع النظرات على أحاضرين & $r$ \\
\hline & & يرفع صوته ويخفضه تبعأ للكلمات و المو اقف الشعرية & \{ \\
\hline & & بقف باعتدال واتزان & $\circ$ \\
\hline & & بنهى الإلقاء الشعرى بطريقة مناسبة & 1 \\
\hline & $\cdot$ & يلقى الشُعر من الذاكرَّ بدون استخام ورقة & $v$ \\
\hline & & بنوع فى نبرة الصوت بطريقة معبرة عن الموقف & $\wedge$ \\
\hline & & يراعى القافية والكلمات الأخيرة في الأبيات & 9 \\
\hline & & بقف عند جملة شعرية لها معنى. & 1. \\
\hline
\end{tabular}

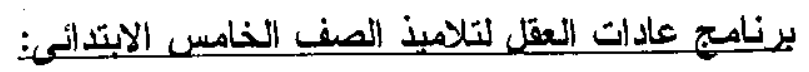

هر إعداد البرنامج بالخطو ات الآتية:

- تحديد عادات المعل المناسبة مع نلامبذ الصف الخامس الابتذائى حيث عرضيت قائمة لعادات العقل على مجمو عة من المحكمين لاختيار أهــم هــذه العـادات

ونمثلت القائمة المبدئية فى (T ا ( ) عادة عقلية وهى:

\begin{tabular}{|c|c|}
\hline ا r الإبداع و التخبل و الابتكار & 1) عادز المثابرة \\
\hline 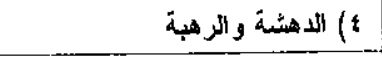 & "ا) التحكم بالتهور \\
\hline 1) القيام بالمخاطرات المحسوبة & •) الاستماع بتفه وتعاطف \\
\hline ^) البحث عن الاعاية & V) التساول وطرح المشكلات \\
\hline . 1. التفكير التبادلى & 9) جمع البياتات بكل الحو اس \\
\hline r r الرغبة في التعلم والاستمر ار & 11) التفكير بمرونة \\
\hline ؛ 1 ) الكفاح من أجل الدقة & rا 1) ما وراء المعرفة \\
\hline ب 11) التفكير و التو اصل بوضوح ودةً & م1 1) تطبيق المعارف الماضية على أوضاع جديدة \\
\hline
\end{tabular}

- مون خلام أر اء السادة المحكمين نم التوصل لأهم العادات العقلية الأكثز أهمية

ومناسبة للمرحلة العمرية لتلاميذ الصف الخامس الابتذائى وهى:

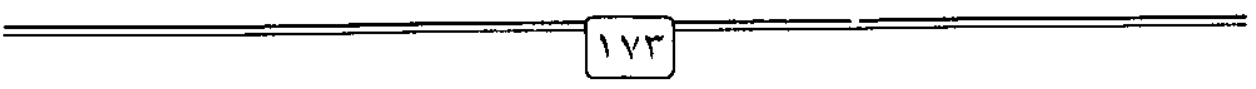




\begin{tabular}{|c|c|c|}
\hline 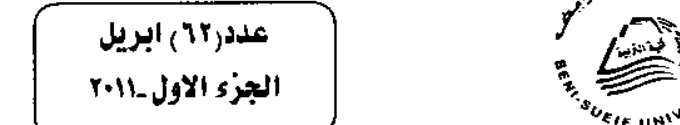 & & مجلة كلية التريبة بويف \\
\hline 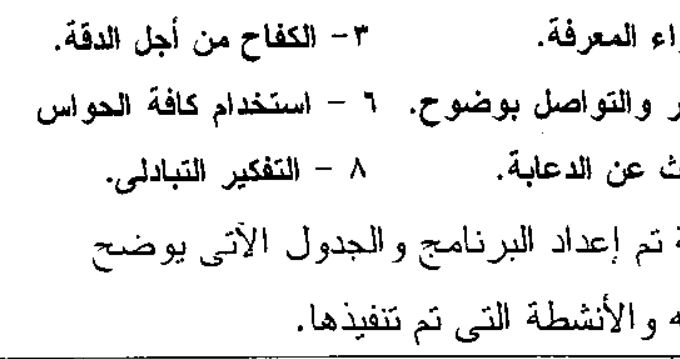 & 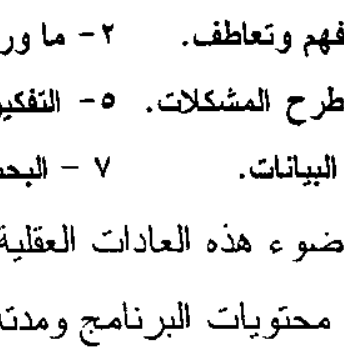 & 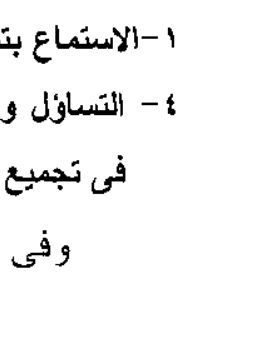 \\
\hline الأشطة التى تم تنفيذها & المهارات الشبعرية & الاروس و المهارات \\
\hline 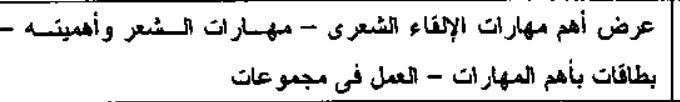 & | نعاذج من الشتر الحايث وإنــاء & 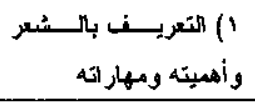 \\
\hline | متل ماذا تفعل. & | استخدام نبرد الصوت المعبرد عن & 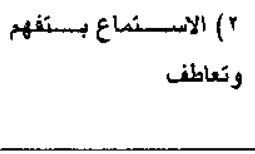 \\
\hline 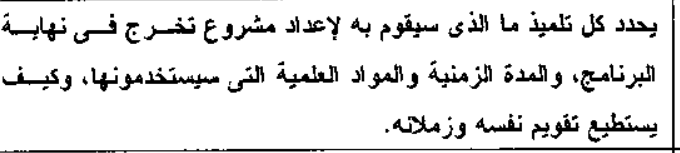 & | ثرز الإمكان & r) ما وراء المبرفة \\
\hline 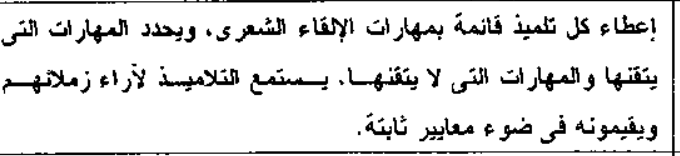 & |ثائمة معايير الإناء الشعرى & 4) أكفاح من أجل الاتة \\
\hline 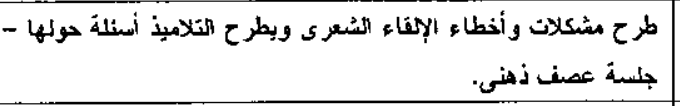 & | الأخطاء الشعرية & 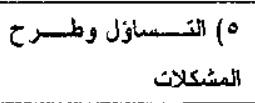 \\
\hline 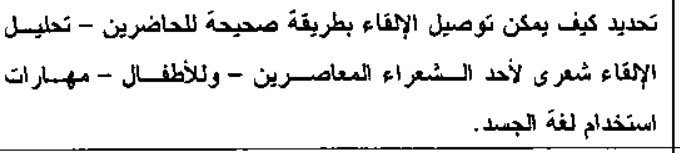 & | بستخدام الإيماءات و الإنشار ات & 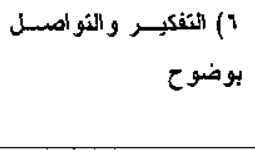 \\
\hline 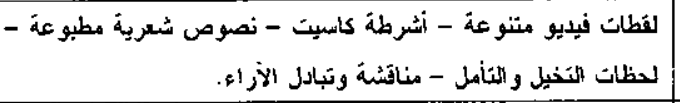 & 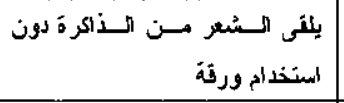 & 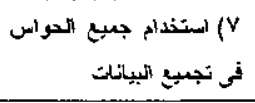 \\
\hline 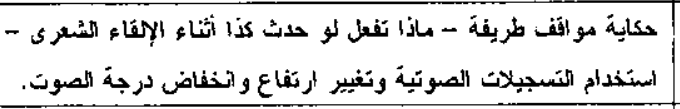 & 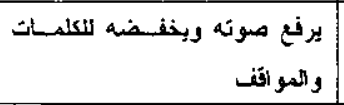 & ه) البحث عن الدعابة \\
\hline | التفكير فى مجمو عات - عرض وجهات النظظر - تعليم التقرين. & 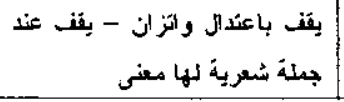 & 9) التفكير المَبَادنى \\
\hline \multicolumn{3}{|c|}{. 1) لفاء مفتوح مع التَلامبذ ومناقَة حرة } \\
\hline
\end{tabular}

- - نم تطبيق البرنامج فى الفترة من 
- متمت ملاحظة أداء التلاميذ من خلا قائمة مهار ات الإلقاء الشعرى من خلا

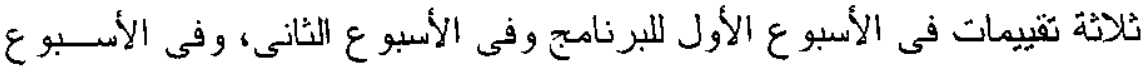

$$
\text { الأخبر للبرنامج. }
$$

وتم رصد نتائج نطبيق بطاقة ملاحظة الإلقاء الشعرى للتناميذ وهم (9) تلاميذ

من (7) مدارس بإدارة ههيا التعليمية بمحافظة الشرقية وكانت النتائج كالآتى:

\begin{tabular}{|c|c|c|c|}
\hline عدد الثلامبذ الذين لديهم & 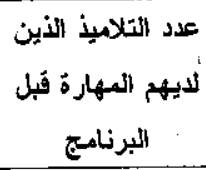 & المهـارة & \\
\hline$v$ & $\mathbf{1}$ & بلقَى الشتعر بصوت و اضتح & 1 \\
\hline 1 & $r$ & بستخدم الإيمائات والإرشادات & $r$ \\
\hline$\wedge$ & $r$ & يوزع النظرات على المحاضرين & $r$ \\
\hline 1 & 1 & برفع صوته ويخفضه تبعأ للكلمات و المو اقف المشتريذ & \{ \\
\hline$\wedge$ & $r$ & 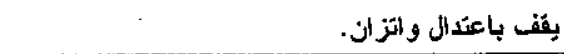 & $\bullet$ \\
\hline$v$ & i & ينه الإمقاء الشعزى بطريقة مناسبة & 1 \\
\hline $\mathrm{v}$ & $v$ & بلقى الشعر من الأكر ذّ بدون استخدام ورقة & $v$ \\
\hline$r$ & $r$ & ينوع في نبرة الصوت بطريقة معبرة عن الموقف & $\wedge$ \\
\hline 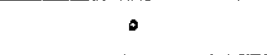 & - & برِ اعى القافية و المكلمات الأخيرة في الأبيات & 9 \\
\hline$\wedge$ & t & يقف عند جملة شعرية لها معنى. & 1. \\
\hline it & $r$ & المجمو ع الكلى & \\
\hline
\end{tabular}

باستخدام البرنامج الإحصائي Spss وبمقارنة نتائج التطبيق القبانسى بالبعـدى لئس

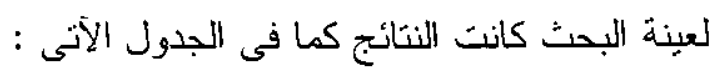

درجات المهار ات الكلية و المجمو ع الكلى فيما يلى :

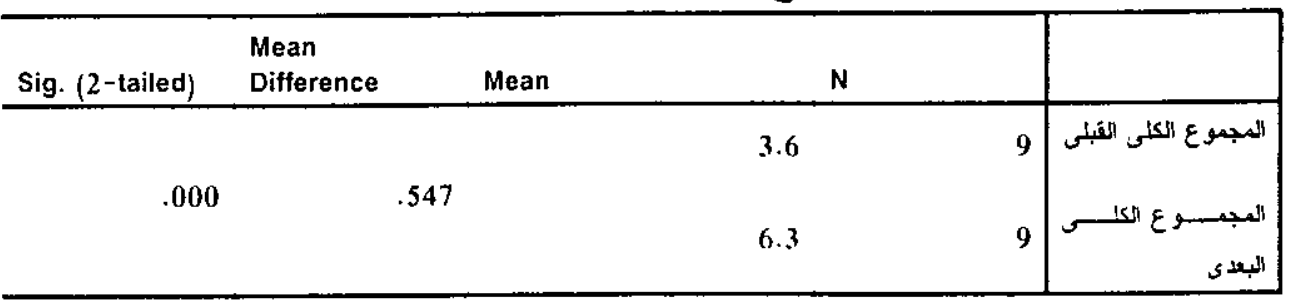




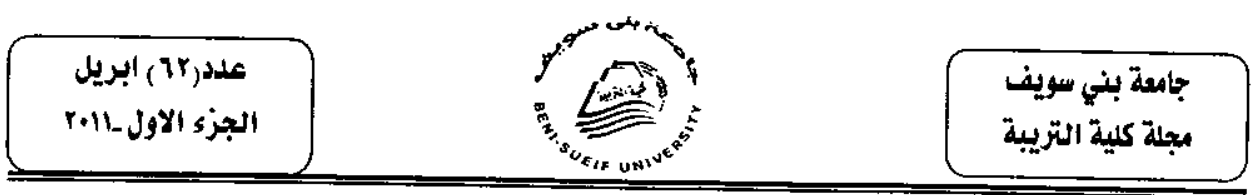

قيمة الفرق بين منوسطى درجات التلاميذ فى الاختبار القبلى و الاختبار البعدى= r, ب

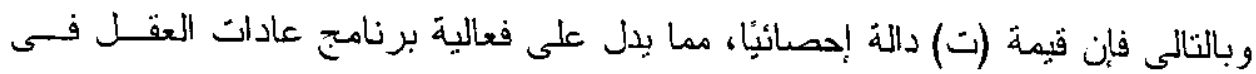
تنمية الإلقاء الشعرى و الموعى بالمو هبة لدى تلاميذ المرحلة الابتدانية.

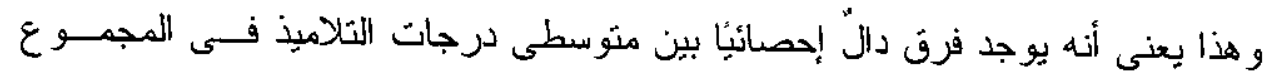

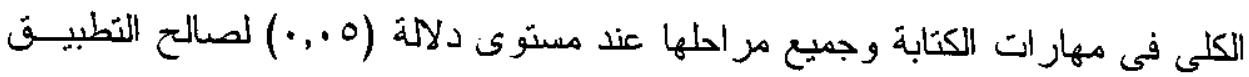

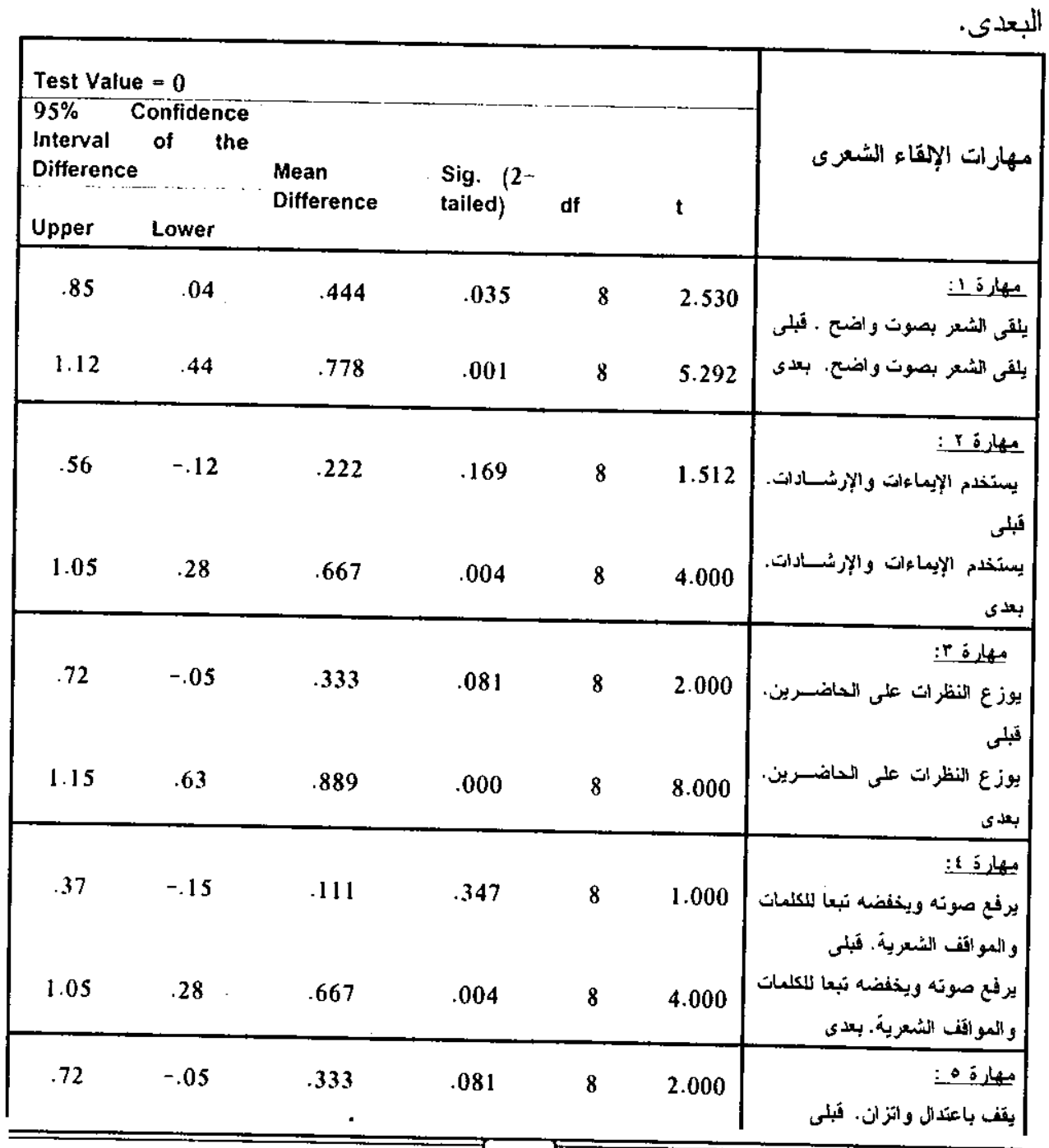




\begin{tabular}{|c|c|c|c|c|c|c|}
\hline ذابريل & علزد & & & & & جاملة بني سويف كلية التريبة \\
\hline 1.15 & .63 & .889 & .000 & 8 & 8.000 & يقف باعثال و اتتزان. بعدى \\
\hline 1.12 & .04 & .444 & .001 & 8 & $\begin{array}{l}2.530 \\
5.292\end{array}$ & 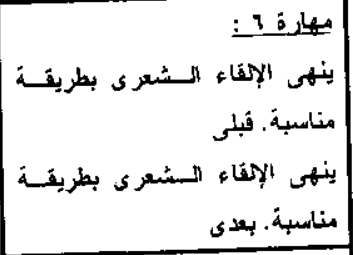 \\
\hline 1.12 & .44 & .778 & .001 & 8 & 5.292 & 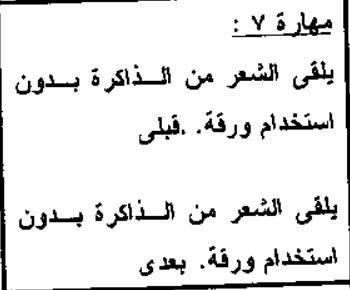 \\
\hline .72 & -.05 & .222 & .081 & 8 & 2.000 & 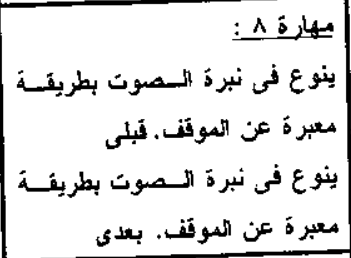 \\
\hline .96 & .15 & .556 & .013 & 8 & 3.162 & 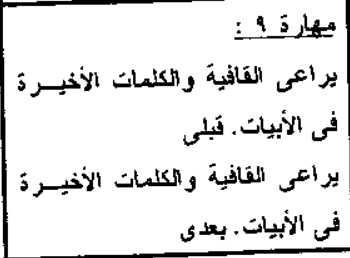 \\
\hline
\end{tabular}

من خلا الجدول السابق بتبين:

- باللنسبة لتزتيب المهار ات الثتى نم اكتسابها أكثر من غير ها كان الثنزيب من الأكثـر

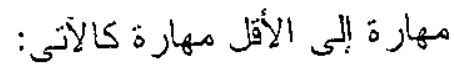

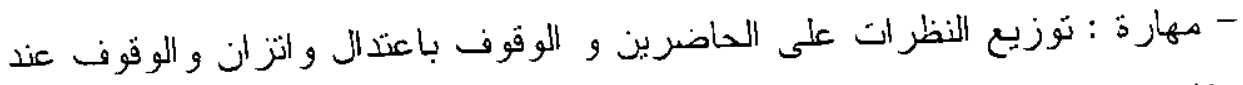

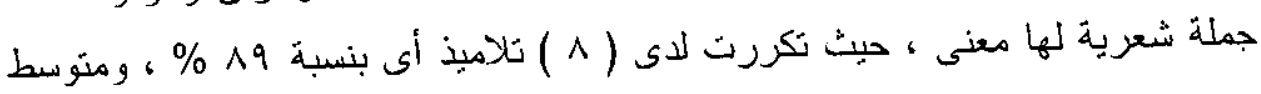




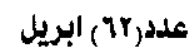

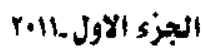

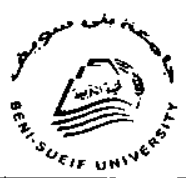

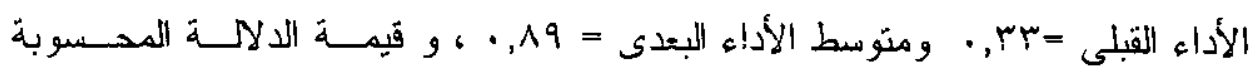

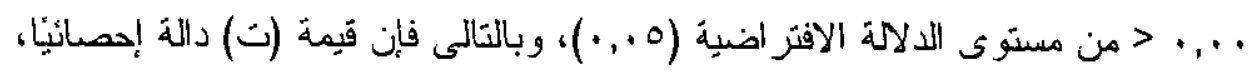

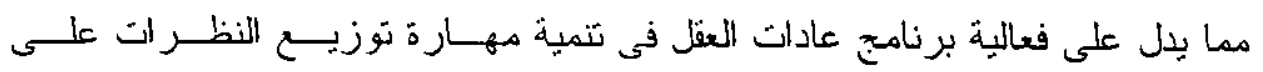

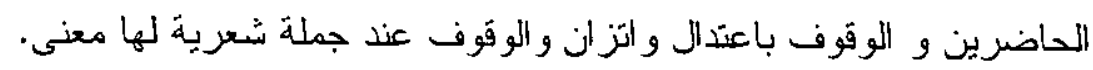

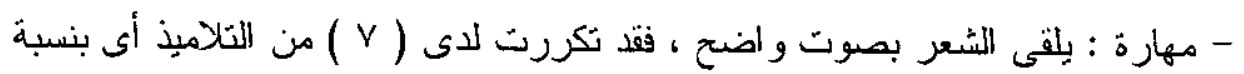
\% VA

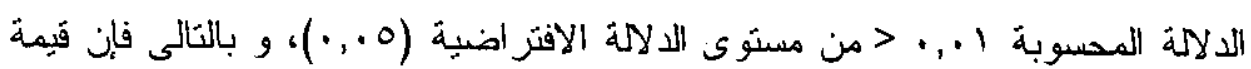

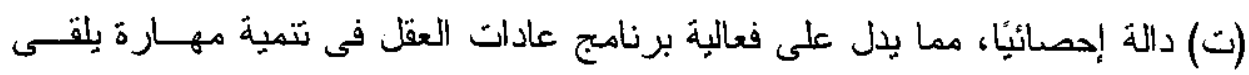
الشعر بصوت و اضنح.

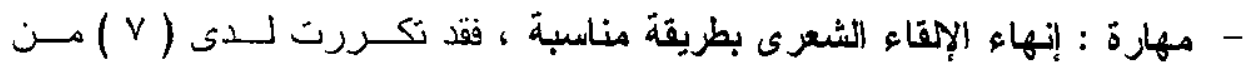

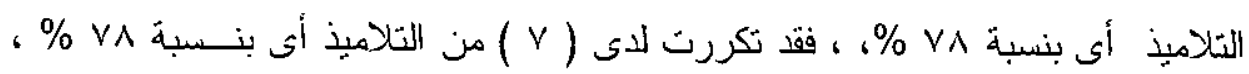

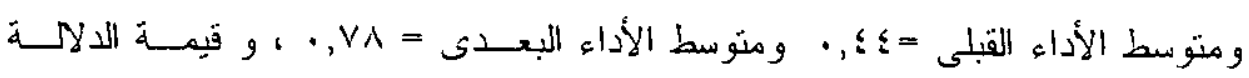

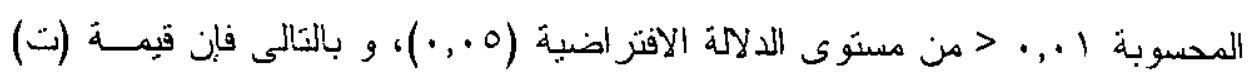

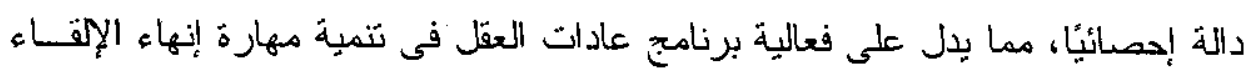
الشعرى بطريقة مناسبة.

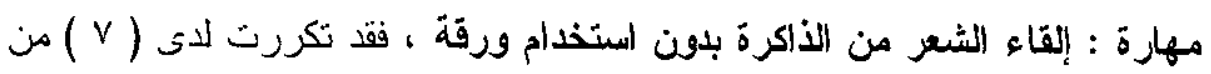

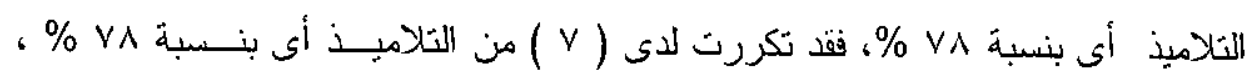

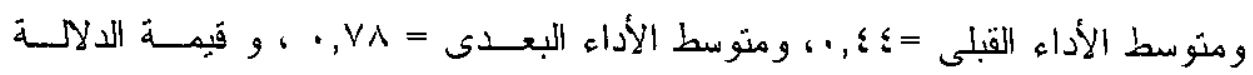
المحسوبة 1. ب.

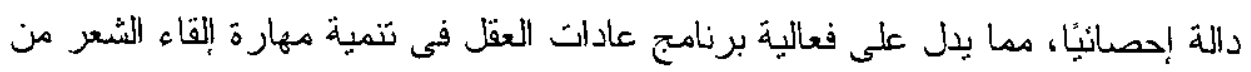
الأذاكرة بدون استخدام ورقة.

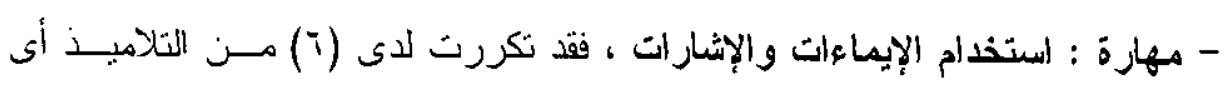

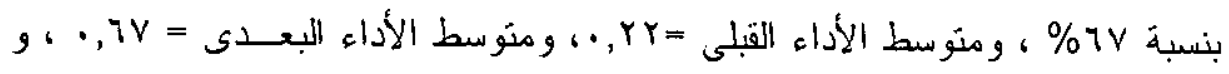


عدد (r) ابتريل

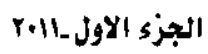

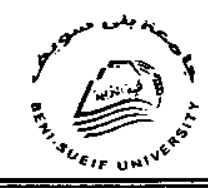

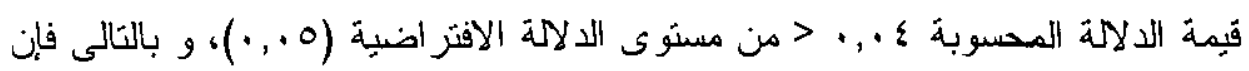

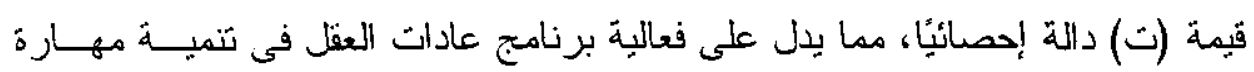

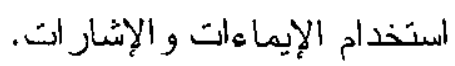
- مهارة : رفع الصوت وخفضه تبعأ للكلمات و المو اقف الثبعرية ، فقد تكررت لأى الأل

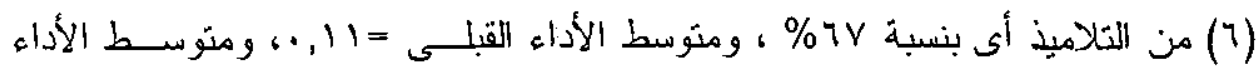

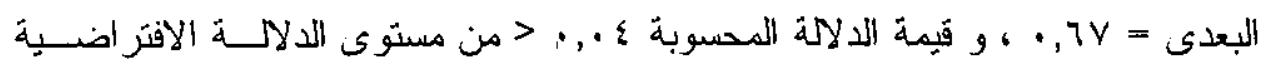

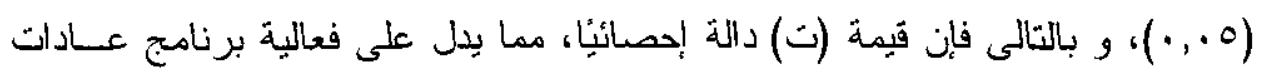

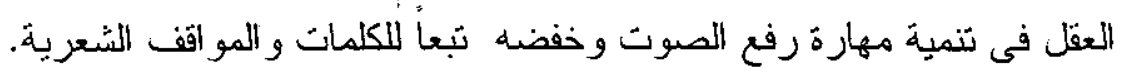

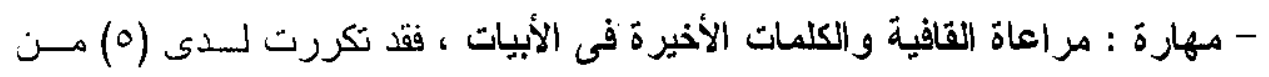

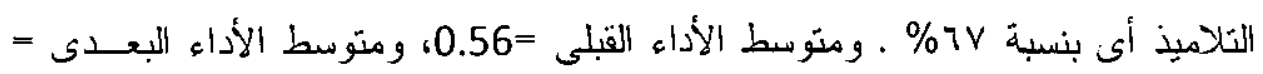

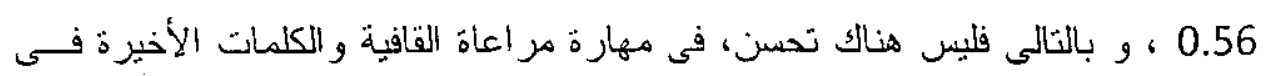
الأبيات.

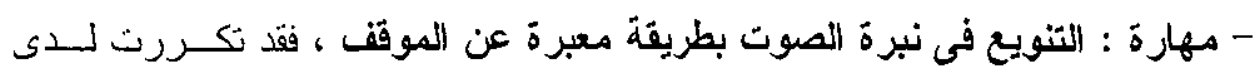

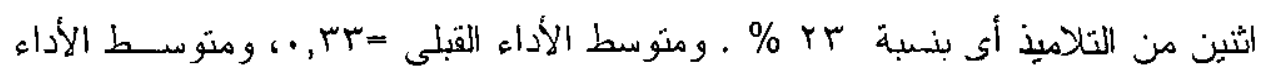

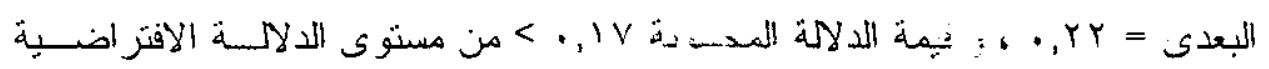

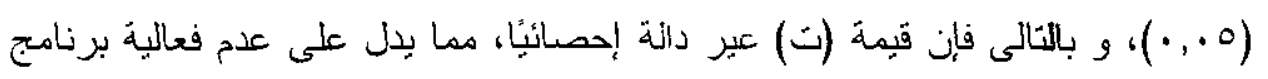
عادات العقل فى تنمية مهارة التنويع فى نبرة الصوت بطريقة معبرة عن الموقف. 


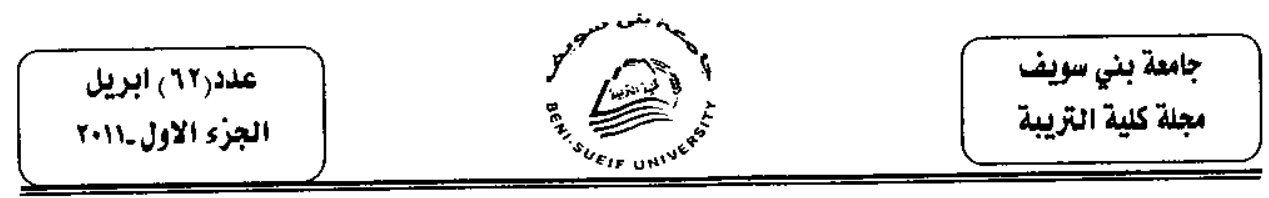

و الجدول الآتى يوضح المهار ات التى حدث فيها نحسن للنتلاميذ:

\begin{tabular}{|c|c|c|c|c|}
\hline "الدين لاديهة & 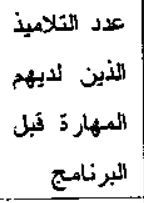 & المهارة & في حدوث نمو المهارة & ? \\
\hline $\mathrm{v}$ & \{ & لـلثى الشعر بموت و اضع & مهار ات حدث فيها & 1 \\
\hline 1 & $Y$ & يستخدم الإيماءات و الإششار ات & ندو وتحسن. & $r$ \\
\hline$\Lambda$ & $r$ & يوز ع النظر ات على الحاضرين & & $r$ \\
\hline 1 & 1 & 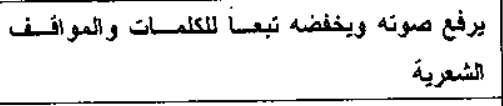 & & $\mathfrak{q}$ \\
\hline$\wedge$ & $r$ & يقف باعتدال واتز ان. & & 。 \\
\hline $\mathrm{v}$ & $\varepsilon$ & بنهى الإقاء الشعرى بطريتة مناسبة & & 1 \\
\hline$\wedge$ & 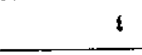 & يقف عند جلة شعرية لها معنى. & & $v$ \\
\hline$v$ & $\mathrm{v}$ & يلقى الشعر من الأكرة بدون استغدام ورتة & مهارات لم يختلف & $\wedge$ \\
\hline • & • & مر اعاة القانية و الكلسات الأخيرة فى الأبيات & 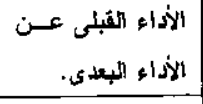 & 9 \\
\hline$r$ & $r$ & ينوع نبر ; الصوت بطريقة معيرة عن الموقف & 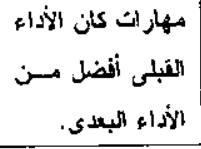 & 1. \\
\hline
\end{tabular}

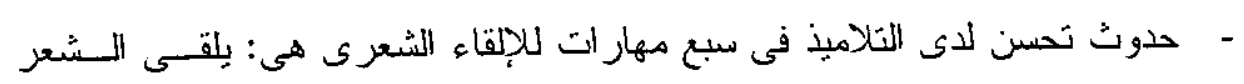

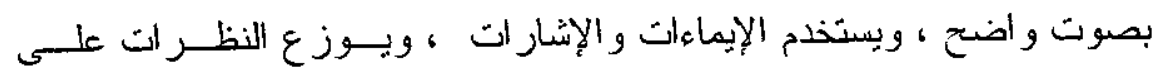

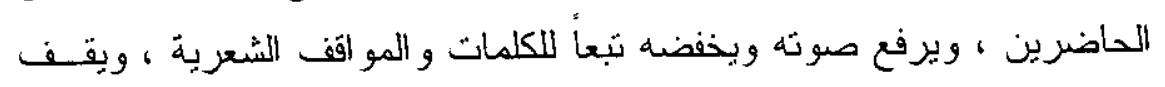

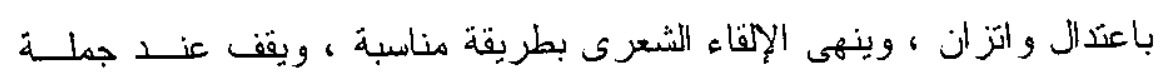
شعربة لها معنى.

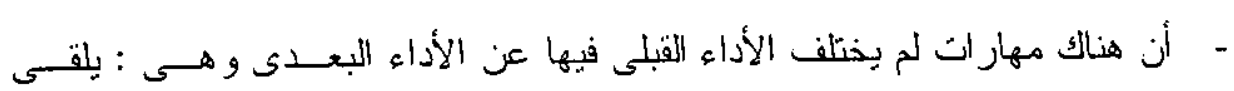

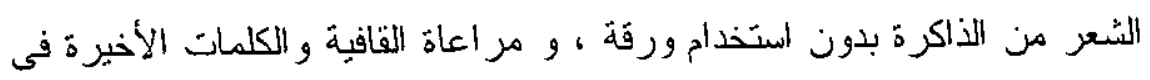
الأبيات.

- أن هناك مهار ات كان الأداء القبلى أفضل من الأداء البعدى وهى : نختلف نبــرة الصوت بطريقة معبرة عن الموقف. 

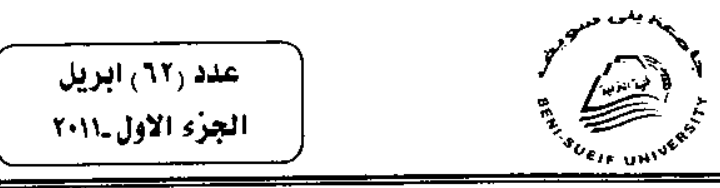

جامعة بني سوريف

ويرجع ذلك لسهولة تعلم بعض المهار ات عن غير ها ، وكذلك الوقت المخسصص

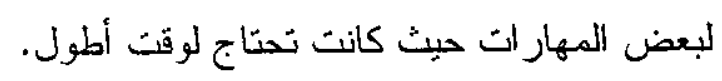

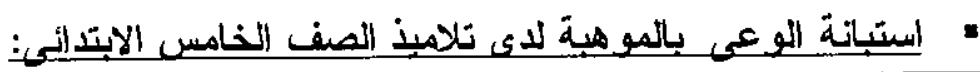

\begin{tabular}{|c|c|c|c|}
\hline \multicolumn{2}{|c|}{ 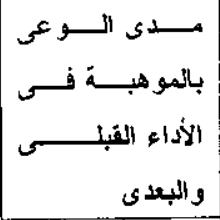 } & \multirow[t]{2}{*}{ 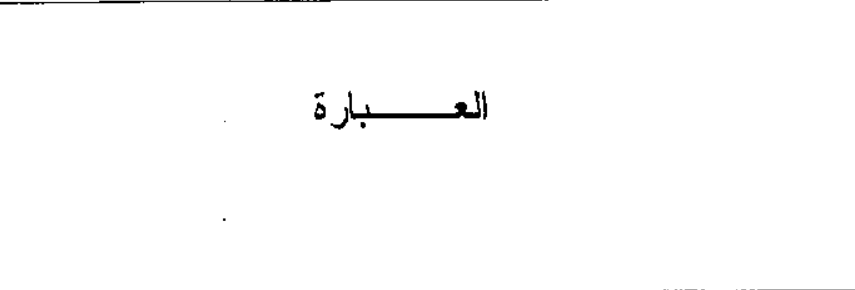 } & \multirow[t]{2}{*}{ s } \\
\hline بعدى | ت بل & 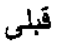 & & \\
\hline$v$ & $\bullet$ & ألقى الشعر بطريقة مميزدّ عن القراعذَ العادية. & 1 \\
\hline • & $\varepsilon$ & أندرب بعد الاتهاء من اليوم الأدرأسى على إلقاء الشعر. & r \\
\hline$\wedge$ & $\bullet$ & لاى مهارات تفوق زملائى فى الفصل أو فى المدرسة في مهارة الإقاء الشعرى. & $r$ \\
\hline $\mathrm{v}$ & $r$ & أسنطيع أن أحدد من الأبيات النى ألثبها إذا كان الشُاعر حزينا أو سعيدأ. & $\mathfrak{q}$ \\
\hline$r$ & $r$ & أطلع على كتب أتشعار بضض الشُعراء المدثنين. & • \\
\hline$\bullet$ & $r$ & أطلب هن معلمى أو زملانى أو و الدى أو و الاتى أن يعرض رأيه في طريقة إلقائى. & $q$ \\
\hline • & $r$ & أسنطيع أن أحدد الجو انب الجيدًَ فى الإلقاء الثشع ى لأى شاعر أو لزملانى فى الفصل. & $v$ \\
\hline 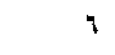 & $r$ & أستطيع أن ألقىى الشُعر مراعيا حالة الشُاعر من الحزن أو الفرح. & $\wedge$ \\
\hline$\wedge$ & $\varepsilon$ & أستخدم إشار ات اليا وإيماءات الر أس وحركة العين فى أثناء الإقاء. & 9 \\
\hline$V$ & $r$ & أستطيع هن الآن أن أخطط لإقاء الشعر فى الآيام أو الأسابيع القادمة. & 1. \\
\hline
\end{tabular}

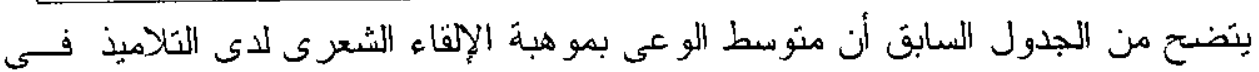

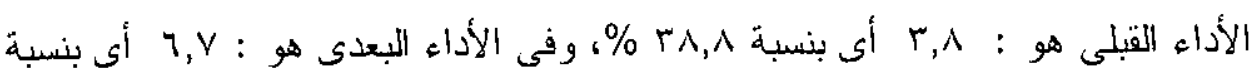

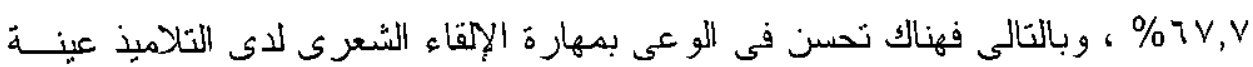
البحث.

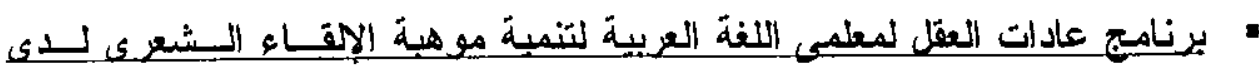

\section{التتلاميذ:}

ولأهمبة المعلم فى العملية التعليمية ، و لأنه لا بمكن استمر ار موهية التلاميذ ونـدعبمها

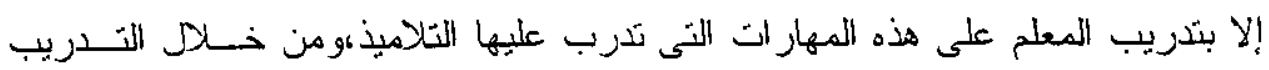




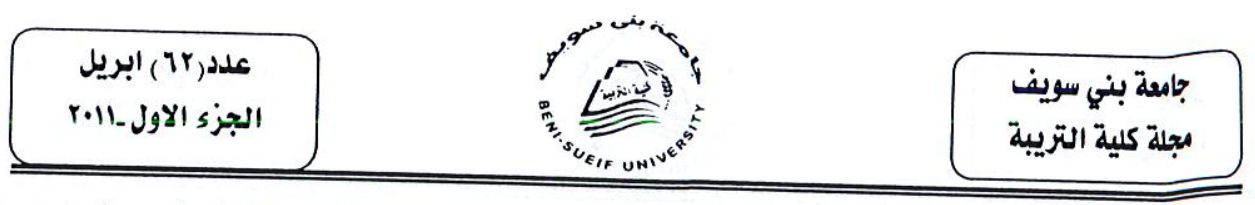

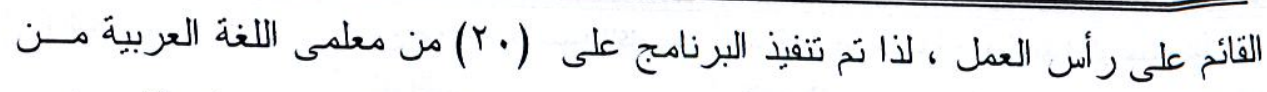

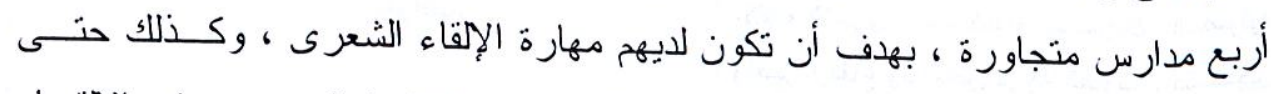

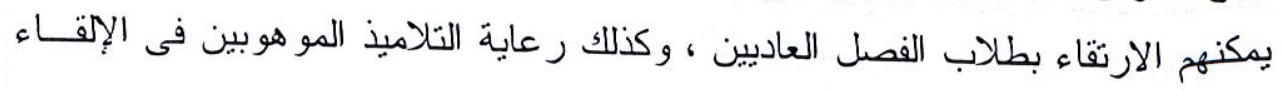

\begin{tabular}{|c|c|c|}
\hline الأشطة التى تم تنفيذها & المهار ات الشُعية & الاروس و المهار ات \\
\hline 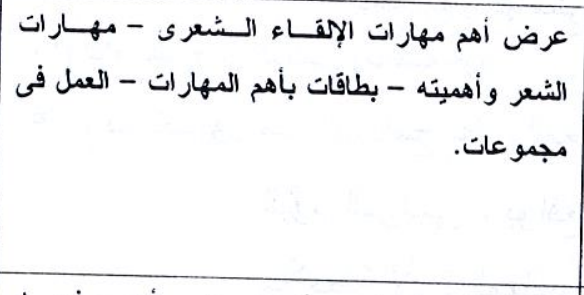 & شماذج من الشَر الحديث بإلقَـاء & 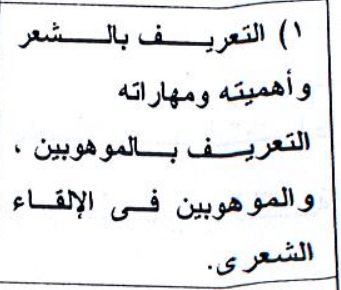 \\
\hline 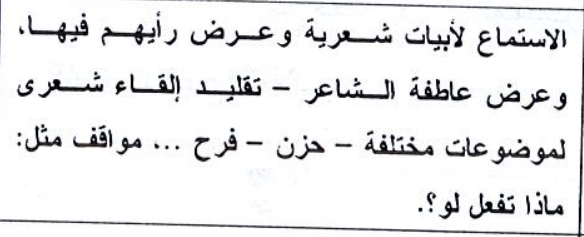 & عن استخدام نبرة الــصوت المعبــرة & 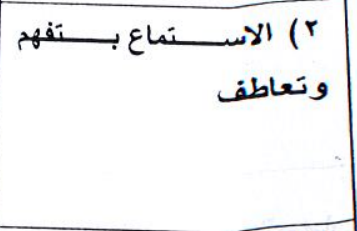 \\
\hline 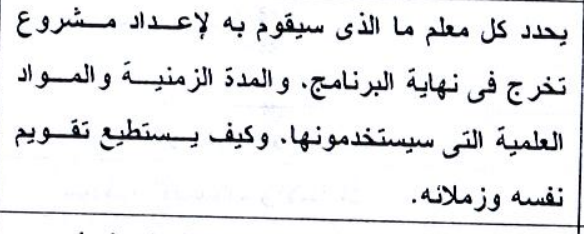 & قدوز الإمكان. & r) ما وراء المعرفة \\
\hline 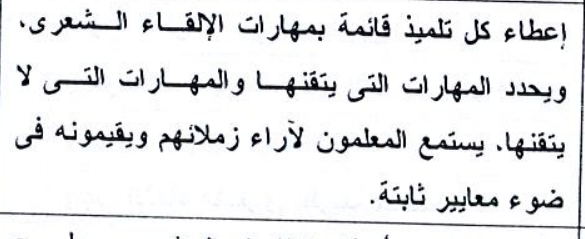 & بتعرف معايِر الإلقاء الشعرى & ع ) الكفاح من أجل الدقة \\
\hline 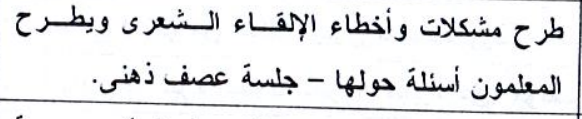 & تعرف الأخطاء الشعرية & 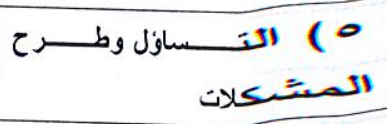 \\
\hline 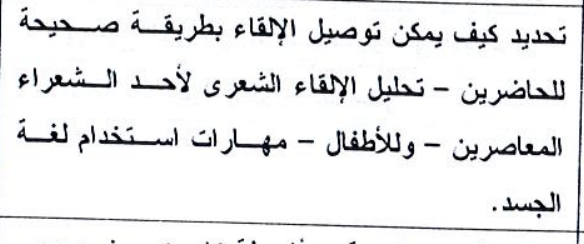 & بستخدم الإِيماءات و الإشار ات & آستفكِـــر و التواصـــل \\
\hline 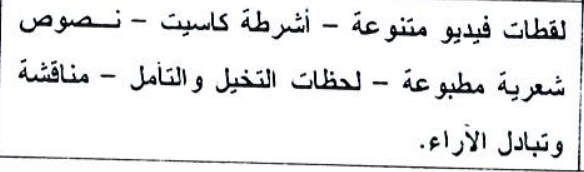 & بِلقى الشَعر مـن الـــاكرة دون & 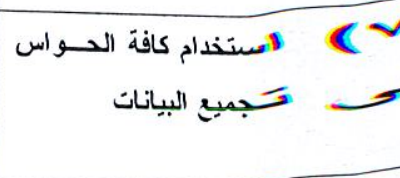 \\
\hline
\end{tabular}




\begin{tabular}{|c|c|c|}
\hline 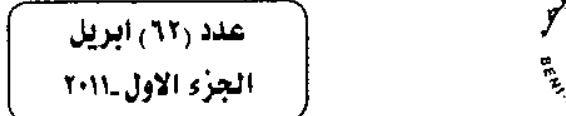 & & جاملة بني سويف كلية التريبة \\
\hline 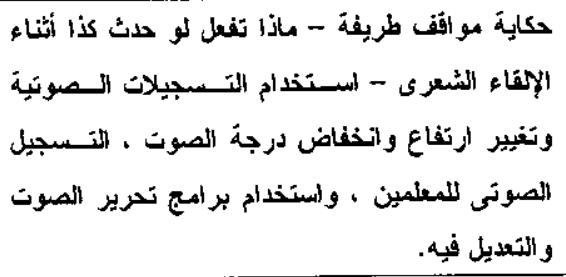 & و يرفع صوته ويخفـــه للكلمــات & ^) البحث عن الدعابة \\
\hline تلتليم القرين. & 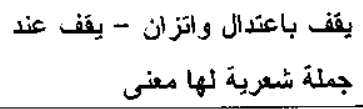 & 9) التفكبر التبادلى \\
\hline \multicolumn{3}{|c|}{ 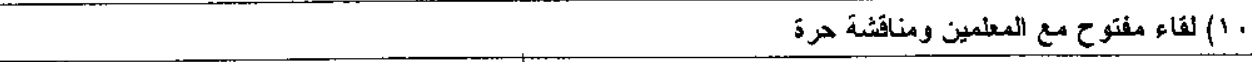 } \\
\hline
\end{tabular}

و تم تطبيق هذا المبرنامج على المعلمين على مدار خمسة أيام متصلة بعــد انتهـاء

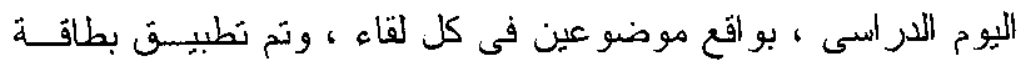

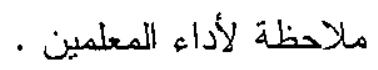

وكانت النتائج كالآتى :

\begin{tabular}{|c|c|c|c|}
\hline بعد تنفيذ البرنامتج المعلين لانهه المهارد & 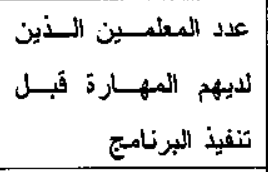 & المــــهــــــــارة & s \\
\hline 17 & 1. & يلقى الثبعر بصوت و اضح & 1 \\
\hline 10 & 9 & بستخدم الإيماءات و الإشارات & r \\
\hline iv & $\mathrm{v}$ & يوزع النظر ات على الحاضرين & $r$ \\
\hline 10 & 9 & يرفيع صوته ويخفضه تبعا للكلمات و المو أقف الشعرية & $\mathfrak{\varepsilon}$ \\
\hline $1 \&$ & 18 & يقف باعتدال واتزان & - \\
\hline 17 & 1. & ينهى الإلقاء الشعرى بطريقة مناسبة & 7 \\
\hline$\wedge$ & $\wedge$ & بلقى الشُعر من الأاكرَّ بدون استخام ورقةة & $v$ \\
\hline iv & 9 & ينوع فى نبرة الصوت بطريقة معبرد عن الموقف & $\Lambda$ \\
\hline 17 & ir & يز اعى القافية والكلمات الأخيرة فى الأبيات & 9 \\
\hline 11 & 11 & بقفف عند جملة شعرية لها متنى. & 1. \\
\hline
\end{tabular}


عدد) البرو البريل

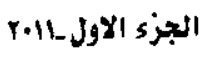

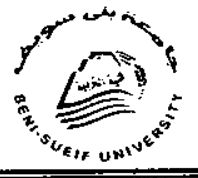

باستخدام البرنامج الإحصائي Spss وبمقارنة نتائج النطبيت القبلى بالبعدى لعينة البحث كانت النتائج كما فى الجدول الآتى :

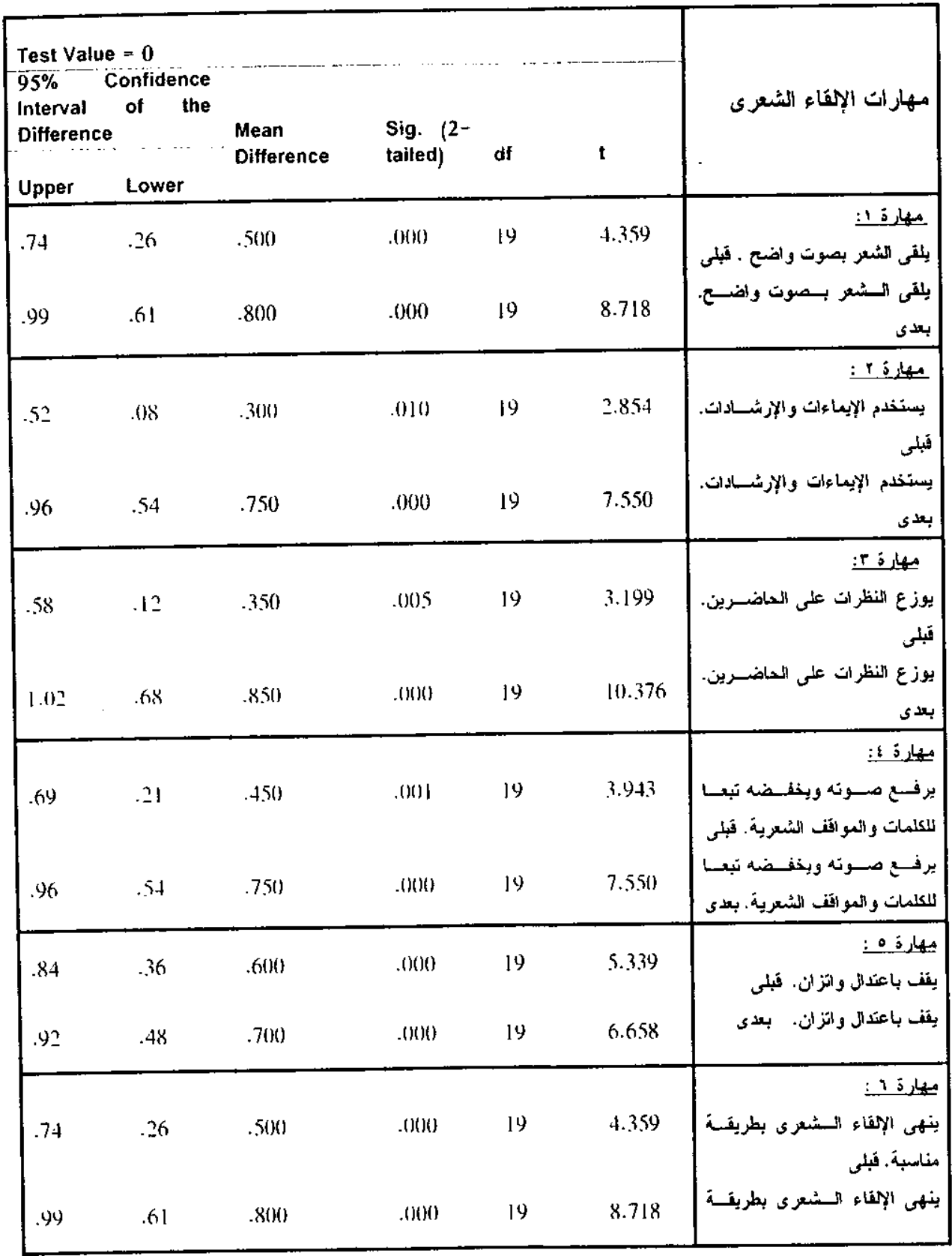




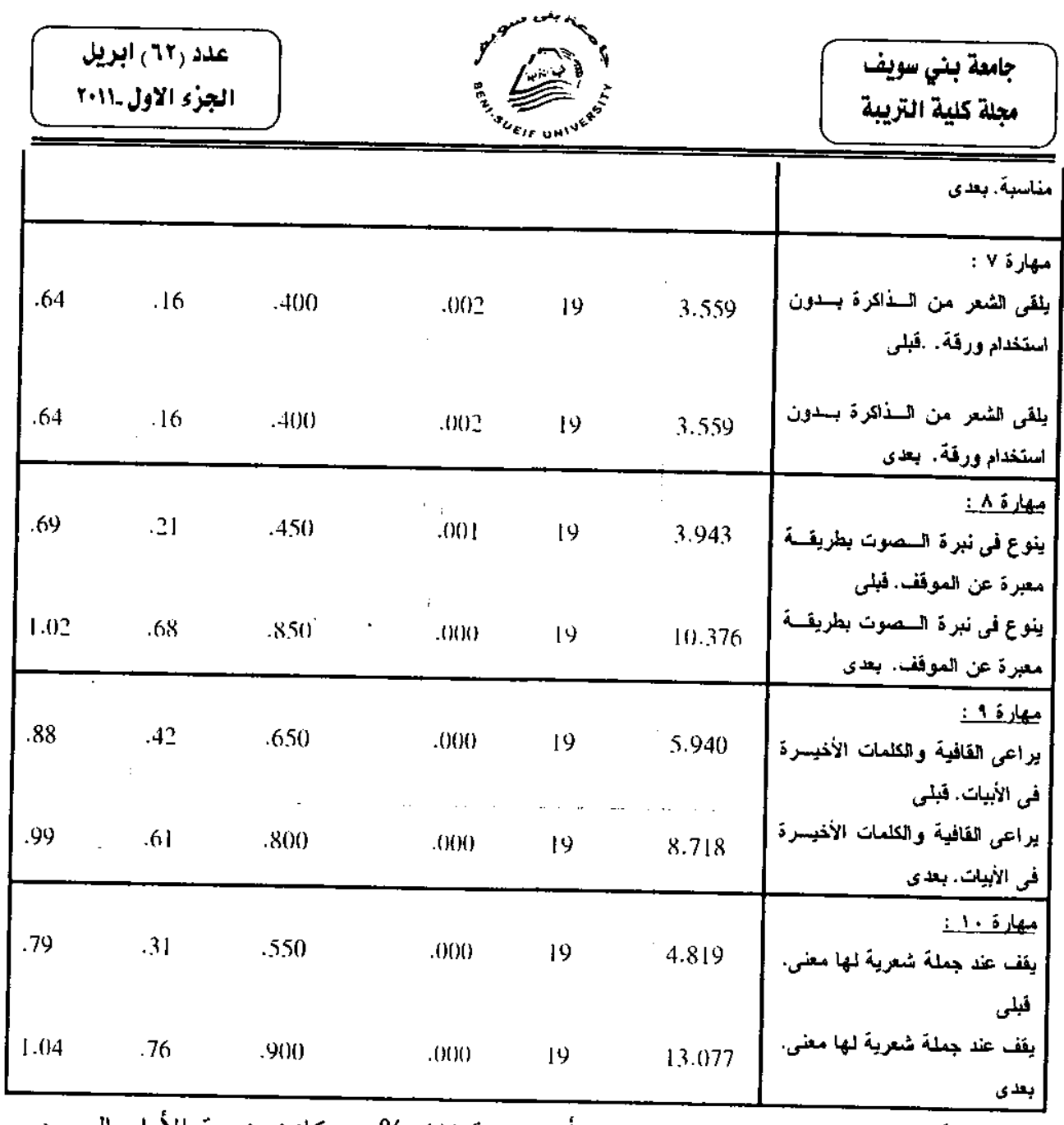

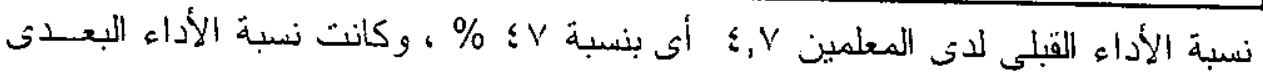
آ, V أى بنسبة ؛ V \% ، وكان ترنيب مهار ات الإلقاء الثنعرى للدى المعلمين كالآتى :

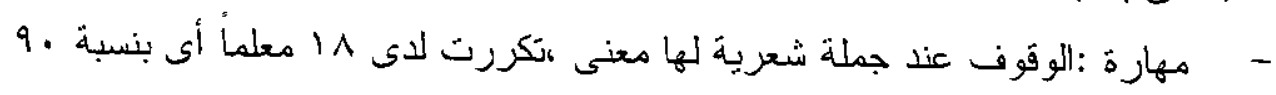

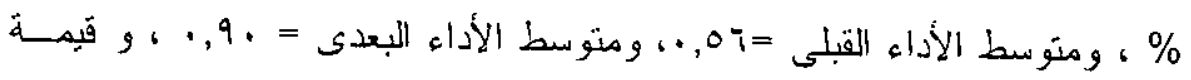
الدلالة المحسوبة . ., > من مستوى الدلالة الافتر اضية (0. •. •)، و بالتالى فإن قيمة (ت) دالة إحصائًا، مما يدل على فعالية برنامج عادات العقل فى ثتمية مهارة الوقوف عند جملة شعرية لها معنى.

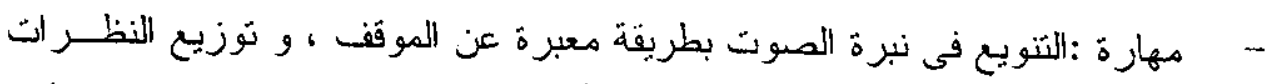

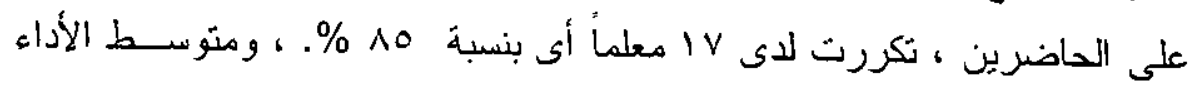




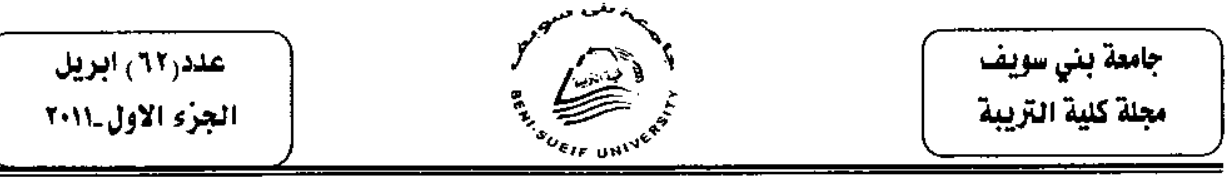

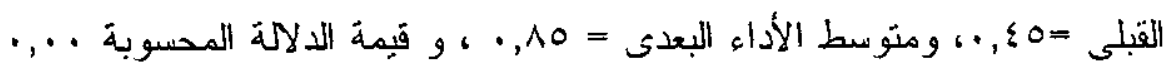

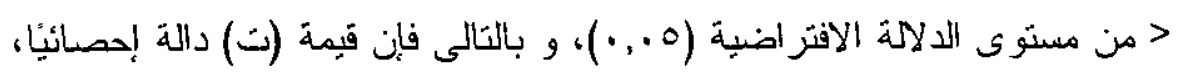

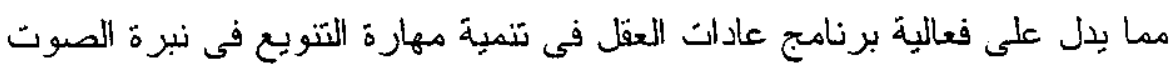
بطريقة معبرة عن الموقوف.

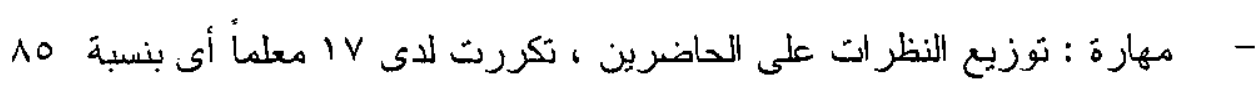

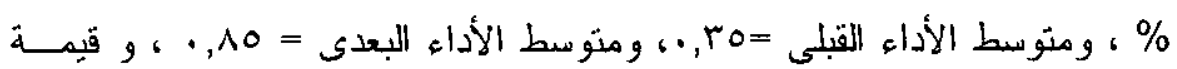
الالامة المحسوبة .... قيمة (ت) دالة إحصائيًا، مما بدل على فعالية برنامج عادات العقل فى تنمبة مهارة توزيع النظر ات على الحاضربن.

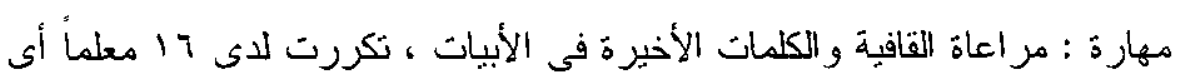

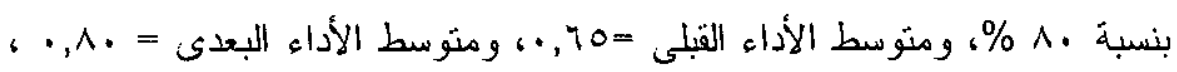

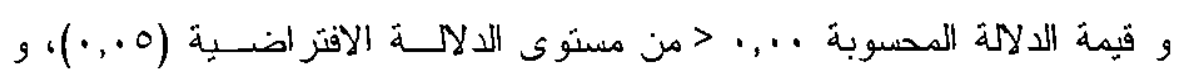

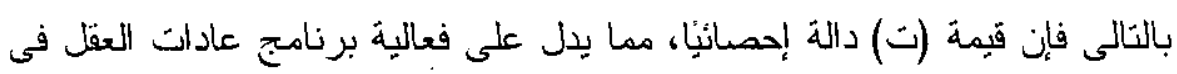
تتمية مهارة مر اعاة القافية و الكلمات الأخبرة في الأبيات.

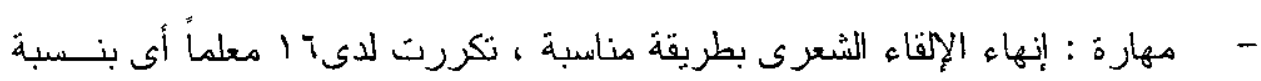

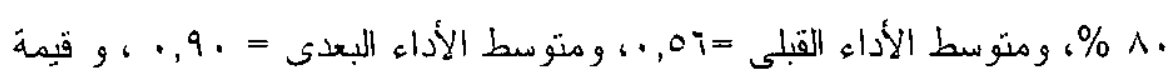

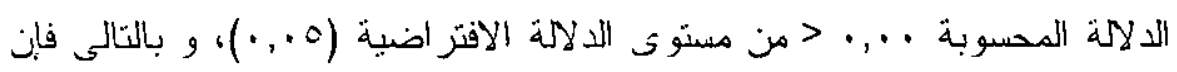
قيمة (ت) دالة إحصائيا، مما يدل على فعالية برنامج عادات العقل فى نتمبة مهازة

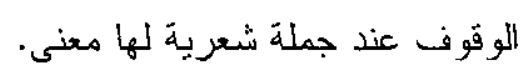

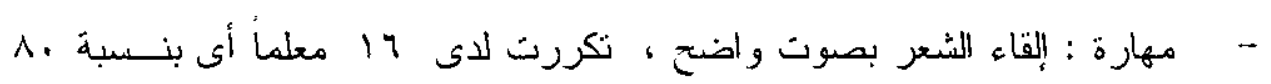

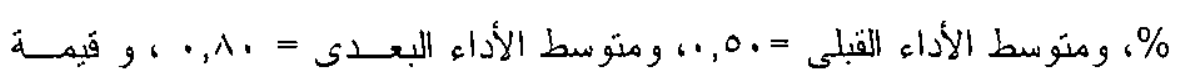

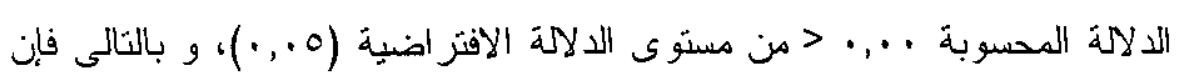




\begin{tabular}{|c|c|}
\hline 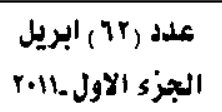 & مجلة كلية بني سلتيبية \\
\hline
\end{tabular}

قيمة (ت) دالة إحصائيًا، مما بيل على فعالية برنامج عادات العقل فى تتمية دهارة إلقاء الشعر بصوت واضح.

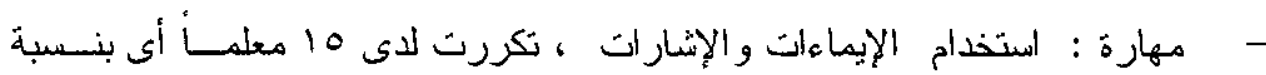

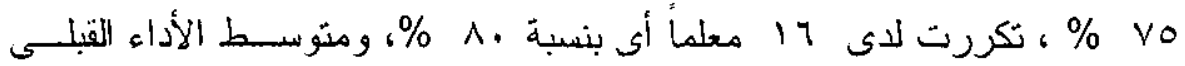

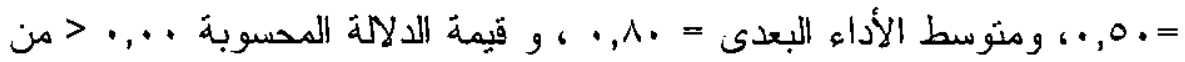

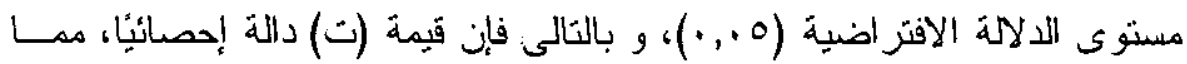
يدل على فعالية برنامج عادات العقل فى تتمبة مهارة إلقاء الشعر بصوت و اضح.

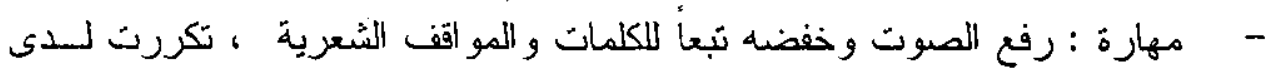

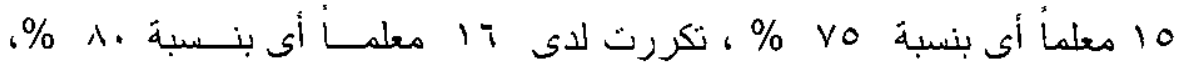

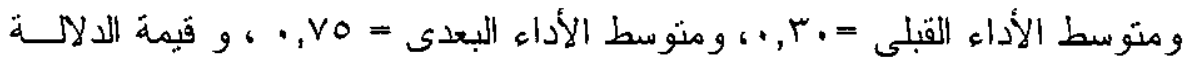

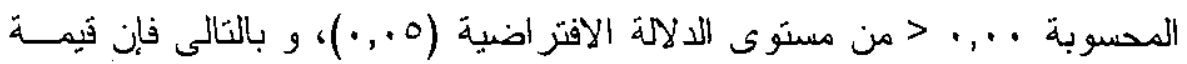
(ت) دالة إحصائيًا، مما يدل على فعالية برنامج عادات العقل فى تنمبة مهارة إلقاء الشعر بصوت واضتح.

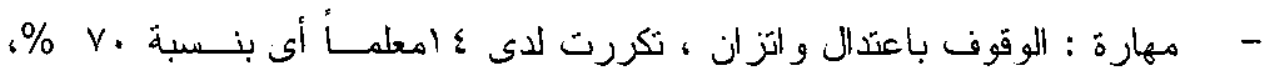

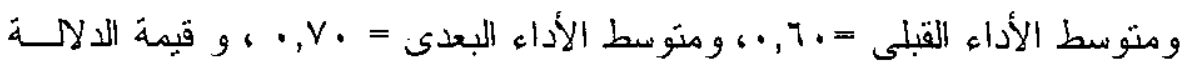

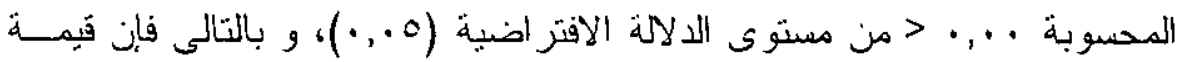
(ت) دالة إحصائيًا، مما بدل على فعالبة برنامج عادات العقل فى تتمبــة مهــارة الو قوف عند جملة شعرية لها معنى.

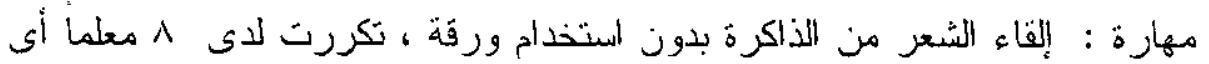

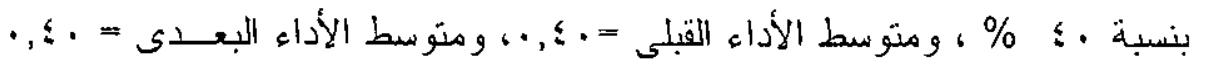
،و يرجع انخفاض الأداء البعدى للمعلمين فى مهارة : إلقاء الشعر من الأكرة بدون

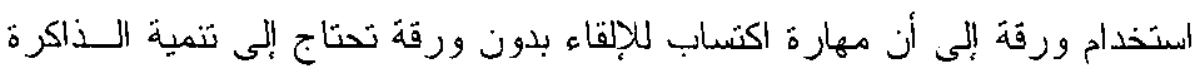
و الحفظ لاى المعلمين ، و هذا ينظلب وفتا أطول مما تم تنفيذ البرنامج فيه. 


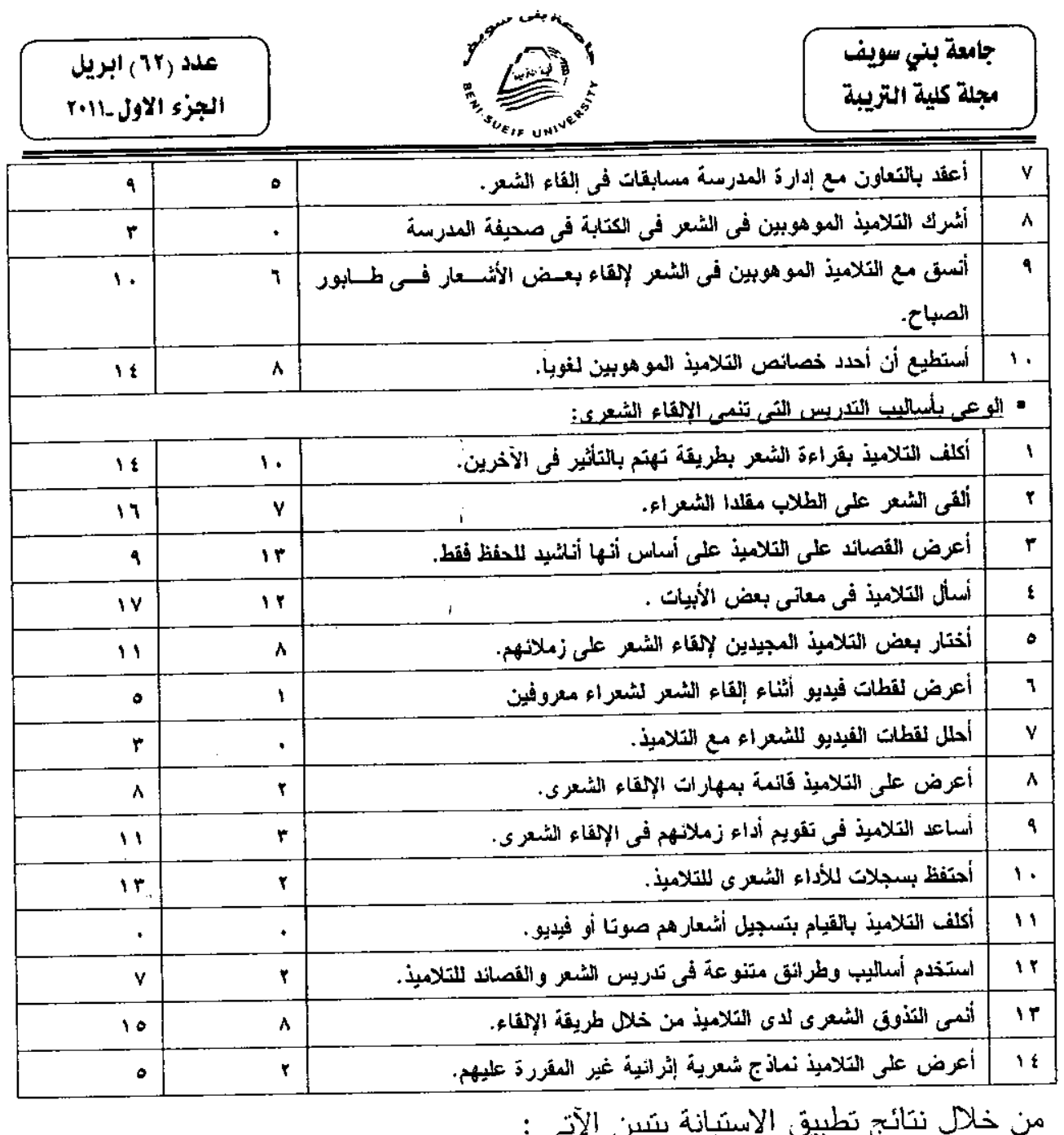

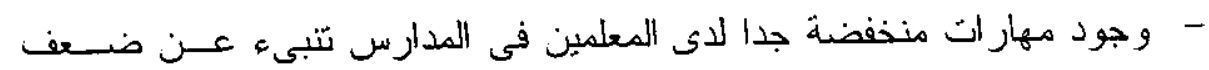

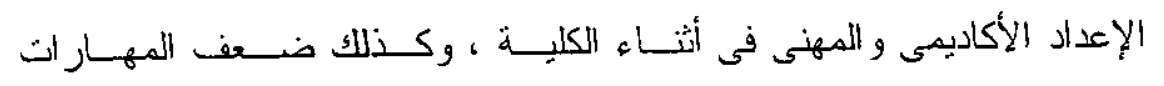

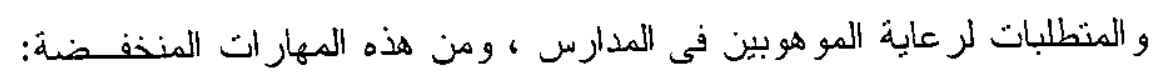

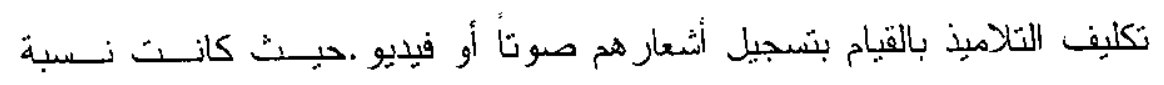

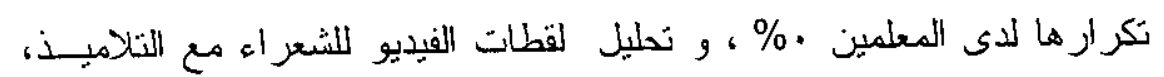

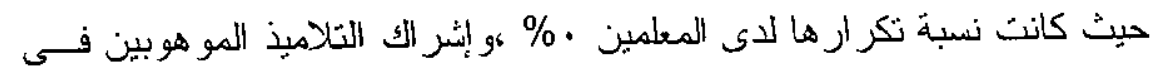
الثعر فى الكتابة فى صحيفة المدرسة حيث كانت نسبة نكر ار ها لاثى المعلمين

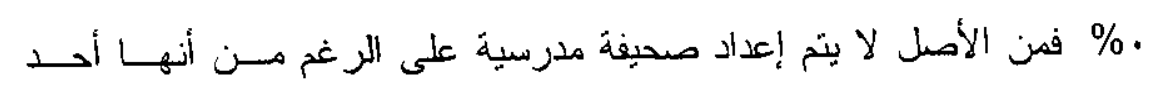




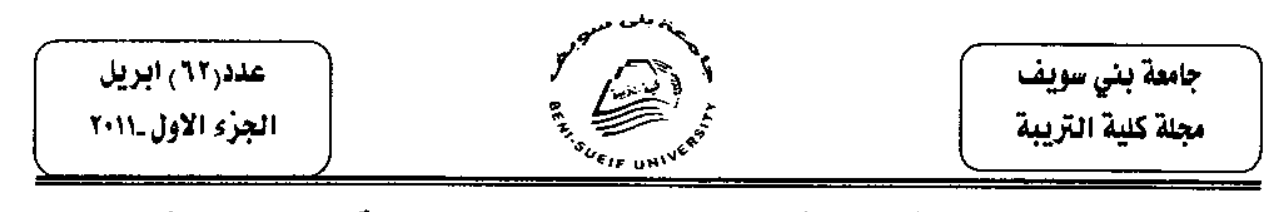

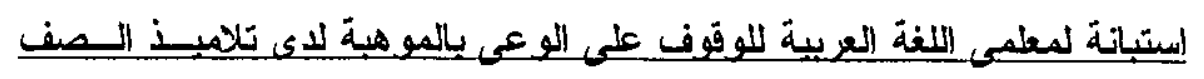

\begin{tabular}{|c|c|c|c|}
\hline \multicolumn{2}{|c|}{ مدى الموعى بالمو هبة } & \multirow[b]{2}{*}{ 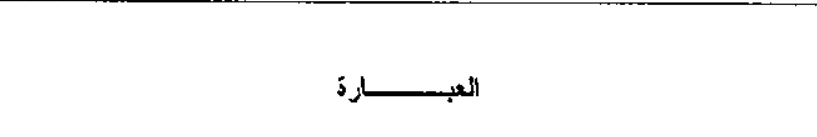 } & \multirow[b]{2}{*}{ r } \\
\hline |أأداء البعدى & الأد1ء القبلى & & \\
\hline \multicolumn{4}{|c|}{ : التوعي باليشبعروأهمبته: } \\
\hline r. & $r$. & أميز بين الشعتر و النثر و الاختلاف بينهما. & 1 \\
\hline in & iv & لدى معرفة بلمسماء بعض المُسر اء القدامى و المشعراء المحدنين. & $r$ \\
\hline ir & 9 & أمتلك مكتبة بها كتب أو اسطو انات مضفوطة لثعراء قدامى أو محدثين. & $r$ \\
\hline iv & 14 & أسنطيع أن أحدد عاطفة الشعر من خلا طريقة إلقائه. & $\varepsilon$ \\
\hline 11 & 10 & أستطيع أن أميز بين مجالات الشُعر المختلفة. & $\therefore$ \\
\hline iv & $\operatorname{lr}$ & أرى أن الشعر في المقام الأول هو تعبير عن الشعور . & 7 \\
\hline ir & ir & أرى أن الشعر الحالى المقام للتلاميذ ينمى جميع جواتب الشخصية لايهم. & $v$ \\
\hline 11 & 11 & أكتب بعض الخو اطر الثُعربة. & $\wedge$ \\
\hline \multicolumn{4}{|c|}{ 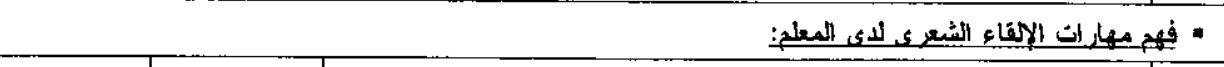 } \\
\hline iv & $\checkmark$ & أتدرب علي الإقاء الشعرى بمنردى. & 1 \\
\hline 17 & $\wedge$ & أضع قائمة بمهار ات الإقاء الشُعرى. & $r$ \\
\hline 1. & 10 & 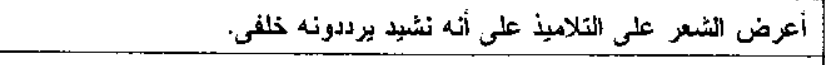 & $r$ \\
\hline$r \cdot$ & $r$. & أرىى أن طريقة الإمقاء للأييات الشعرية لها ثأثير أكبر من مجرد فراءذ الشعر. & $\mathfrak{q}$ \\
\hline iv & 11 & أميز بين الحركات و الإشارات المختلفة للعيز و الميد ودلالها. & $\circ$ \\
\hline 10 & 1. & أسنطيع أن أميز بين مهار ات الإلقاء بصفة عامة ، و مهارات الإقاء الثمرى. & 1 \\
\hline 1 is & 11 & أسنطيع أن أميز بين مهارات الإلقاء إلشعرى .و مهار ات عزض قصة . & $v$ \\
\hline 1. & 18 & لـثناء إلقاء التشبر أتجنب النظظر في عيون الحاضرين. & $\wedge$ \\
\hline \multicolumn{4}{|c|}{ - فهو الموهبة و اكتثبافهيا لدي المنعلمين: } \\
\hline iv & 1. & أستطيع أن أمبز بين التلاميذ في الإلقاء الشسرى. & 1 \\
\hline 9 & $r$ & أعد ملف إنجاز للتلامبذ فى مجال الشعر . & $r$ \\
\hline$v$ & $r$ & أخصص وقتا إضافيا للتّلامبذ المو هوبين في إلقاء الشتعر. & $r$ \\
\hline$\varepsilon$ & $\cdot$ & لدى أستشير الإخصانى الاجنماعى و النفسى فى كيفية تنمية مو هبة الإققاء الشعرى & $\varepsilon$ \\
\hline 1. & $\underline{t}$ & أتو اصل ميع زملائى المعلمين بشأن بعض التلامبذ المو هوبين. & 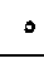 \\
\hline 10 & ir & أصنف التلامبذ المو هويين لفويا إذا كاتث الموهبة فى : الأصدة أو السـشعر أو & 7 \\
\hline
\end{tabular}




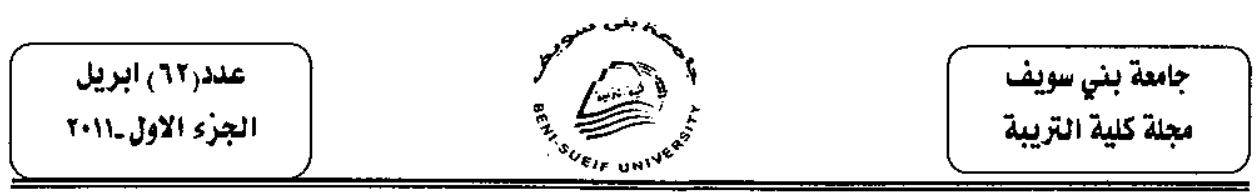

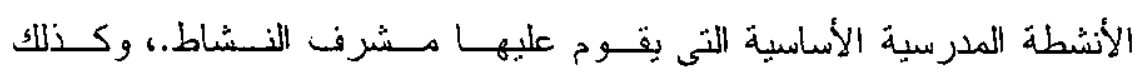
و استشارة الأخصائى الاجتماعى و النفسى فى المدرسة عن كيفية تتمبية مو هبة الاسية

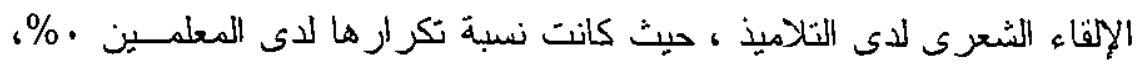

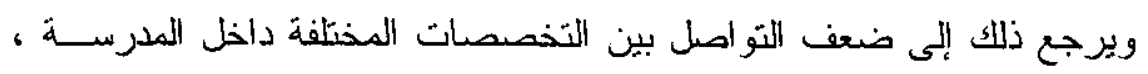

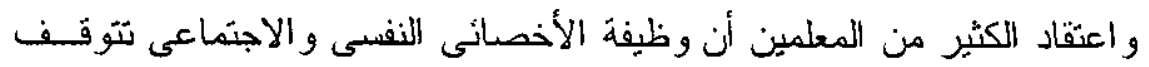
على التُلاميذ ذوى الاحتباجات الخاصة ، وليس الاهنمام بالمو هوبين ، وكذلك: عرض لقطات فيديو أثناء إلقاء الشعر لشعر اء معروفين فقد كان نسبة نكرارها

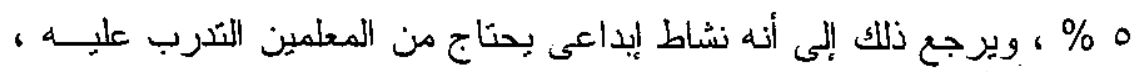
وأن يولو ا اهتمامأ كبير أ بالمتعلمين.

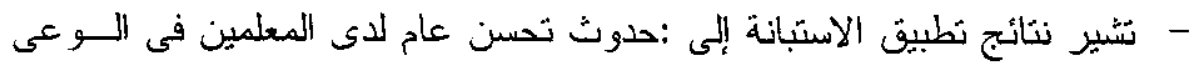

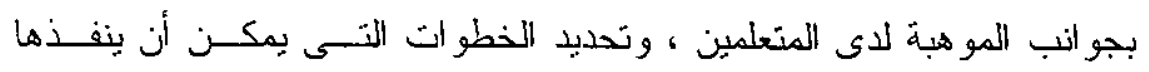

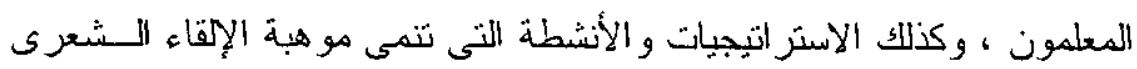

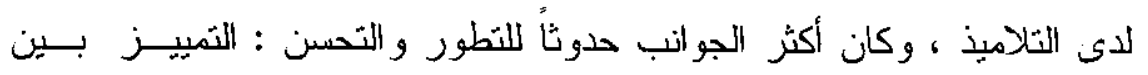

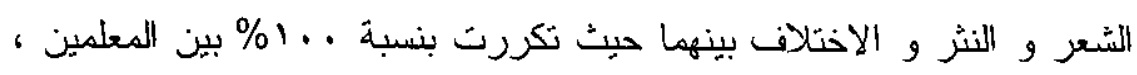

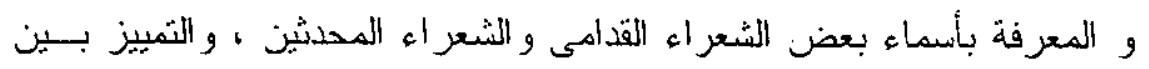
مجالات الشعر المختلفة.حيث تكررت بنسبة ، 9\% من المعلمين.

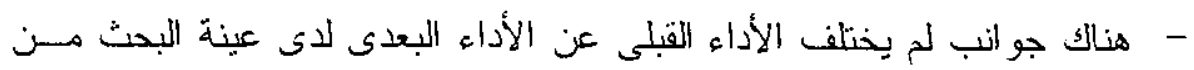

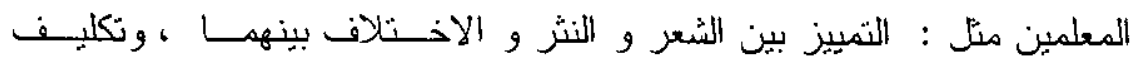
التنلامبذ بتسجيل أشعار هم صونأ أو فيدبو ، و كتابة بعض الخو اطر الشعرية. 


$$
\begin{aligned}
& \text { علد (rا ) ابريل }
\end{aligned}
$$

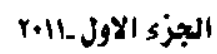

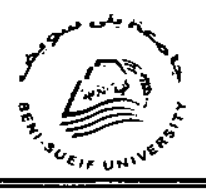

جامعة بني سبويف مجلة كلية التريبة

ملاحظات على تطبيت البحث :

- من الملاحظ أن التلاميذ كان لديهم حماس شديد لتعلم مهار ات الإلقاء الشعرى ،

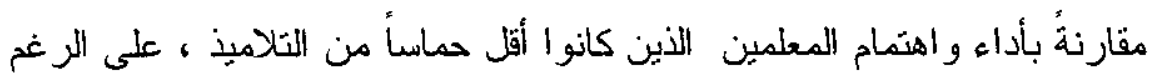

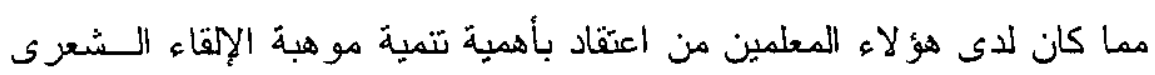

$$
\text { لأى هؤ لاء المتعلمين. }
$$

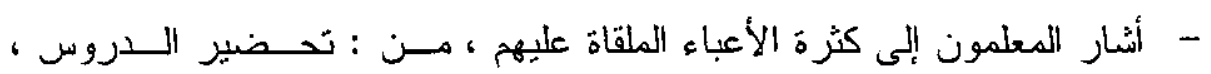

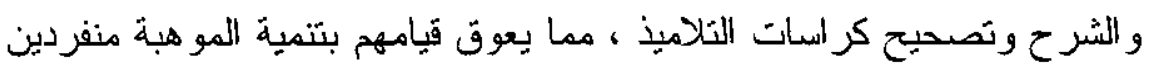

$$
\text { دون مساعدة من الآخرين. }
$$

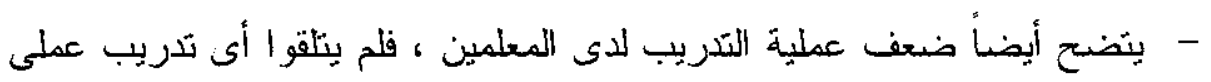

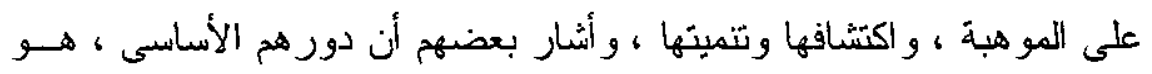

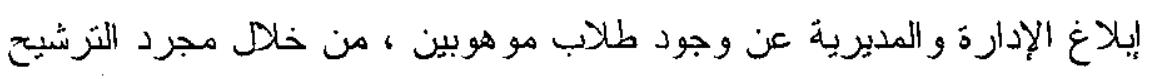
فقط ، دون نطبيق الاختبار ات و المقاييس ، وتحليل أداء المتعلمين. 


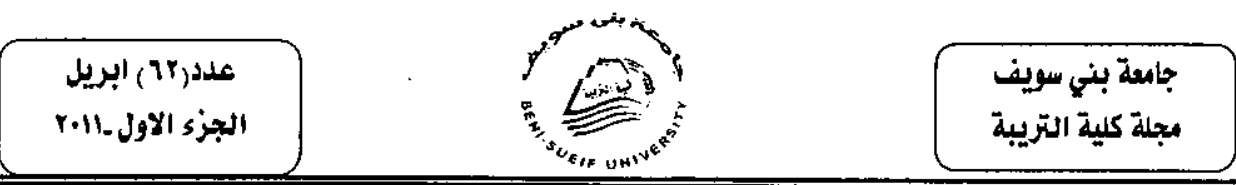

• توصيات البحث:

فى ضو ء ما توصل إلبه البحث من نتائج يوصى البحث بــ:

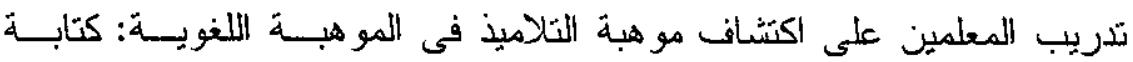

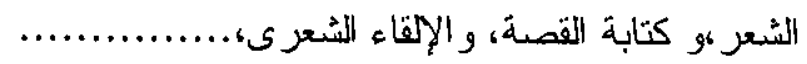

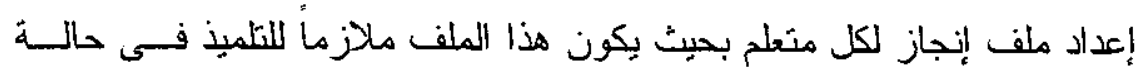

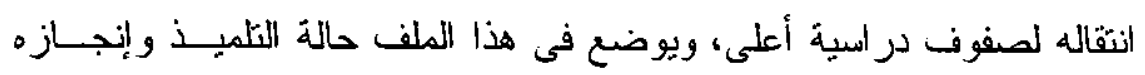
ومجالات المو هبة لايه - إن وجدت.

تدريب المعلمين على عادات العقل المنتجة فمن خلال ذلك يمكنه غرس هـذه وهنه العادات لاى المتعلمين. إنشاء مر اكز للمو هبة داخل المدارس أو فرق لاكتشاف المو هبة وتنميتها ويستح تدريبهم على التعامل مع المو هوبين ور عايتهم.

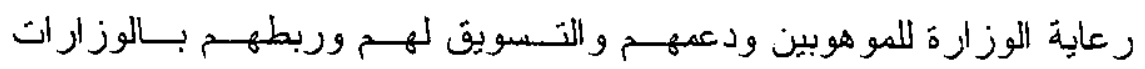
و المجالات الثى يمكن من خلالها تتفيذ وتطبين مجالات المو هبة لديهم.

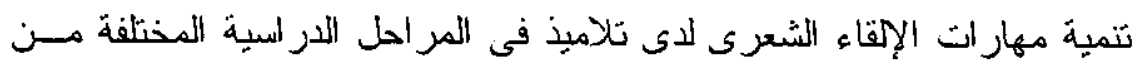
خلا النعاون بين معلمى اللغة العربية ومشرفى الأنشطة بالمدارس.

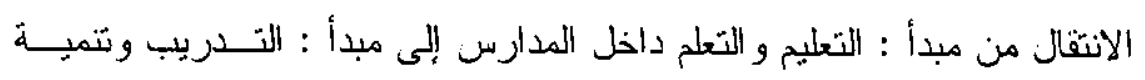

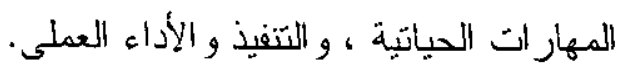
تفعيل التو اصل بين شعبة الأنشطة ور عاية المو هوبين بالمركز القومى للبحوث

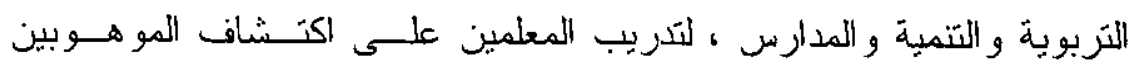

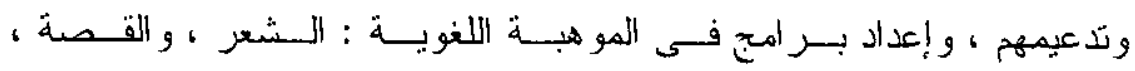

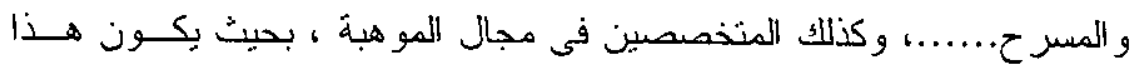
التو اصل بمثابة إشر اف تربوى للمو هو بين فى المدارس. ثبنى وز ارة التربية و التعليم لفكرة مشرو ع قومى لئر عاية المو هو بين. 


\section{• أولا : المراجيع العريية:-}

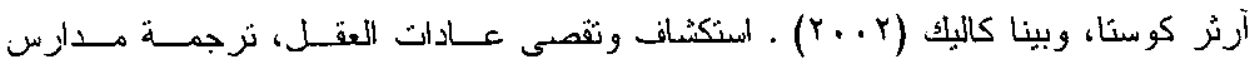

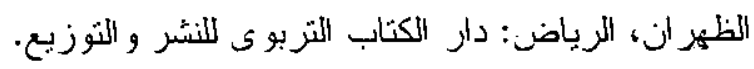

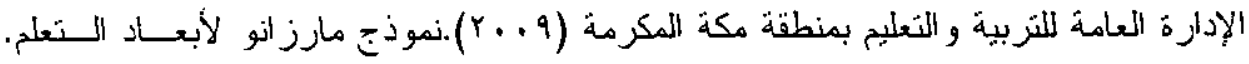

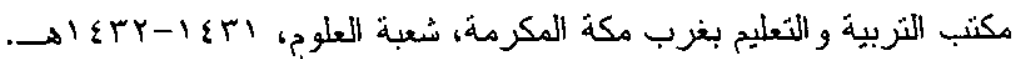

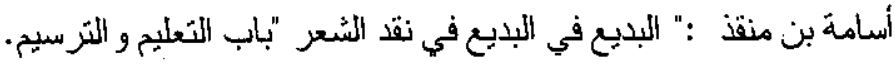

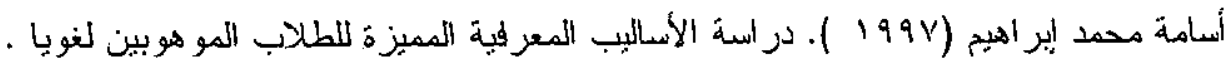

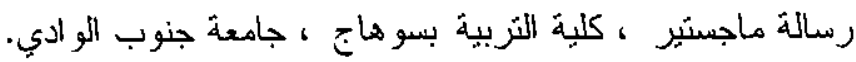

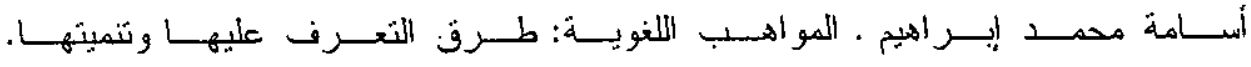
http://www.abegs.org/Aportal/Article/showDetails?id=2017

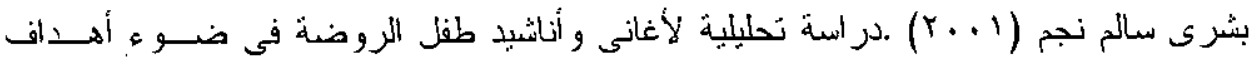
التزبية اللغوية و الموسيقية.رسالة ماجستير ، كلية البنات، جامعة عبن شمس.

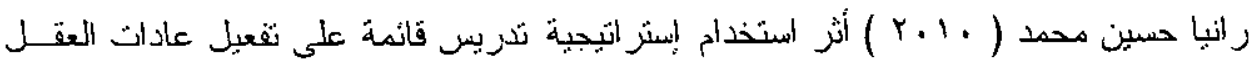

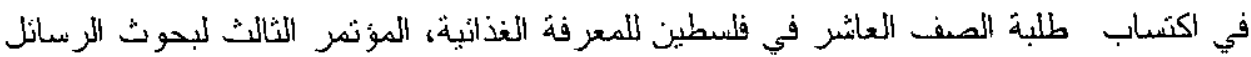

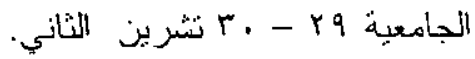

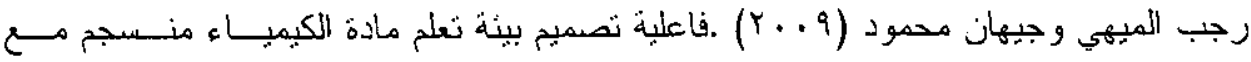

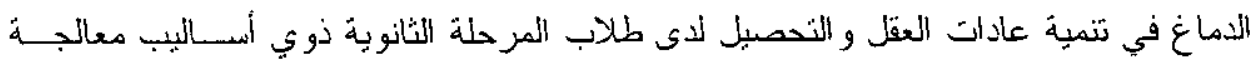

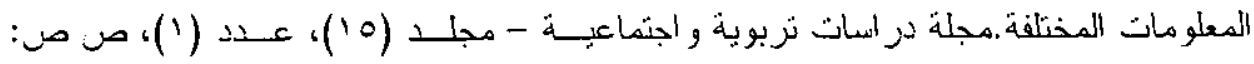
$. r=1-r .0$

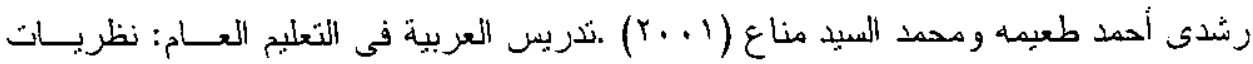

$$
\text { وتجارب.القاهرة : دار الفكر العربى. وندئ. }
$$

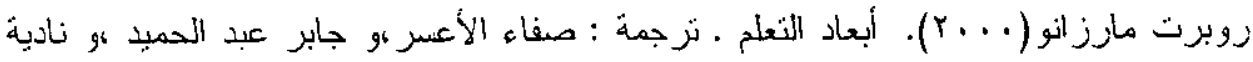

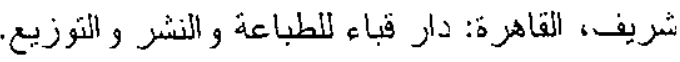

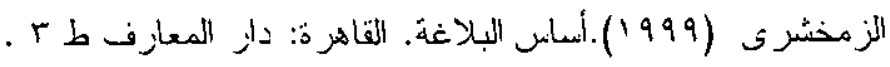




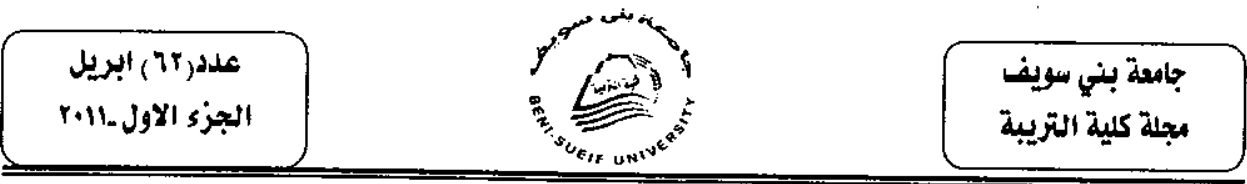

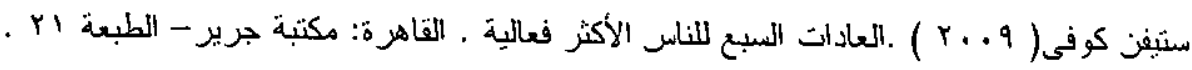

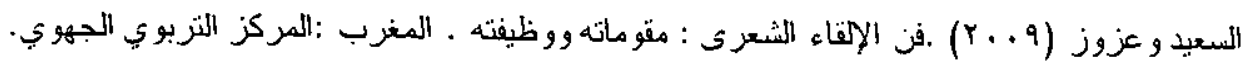

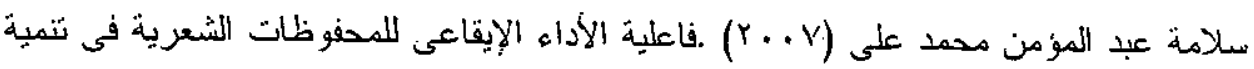
مهار ات القزاءة الأدائية والاتجاه نحو اللغنة العربيية لدى تلاميذ الصف الخامس الابتدائى.رسالة ماجستبر، معهد الدر اسات الثربوبية، جامعة القاهرة.

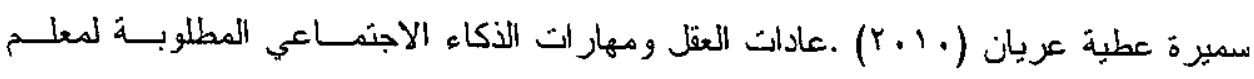
الفلسفة و الاجنماع في القرن الحادي و المشرين. مجلة در استات في المناهج وطرق التـدريس،

$$
\text { عدد (100)، ص ص: • • (100) }
$$

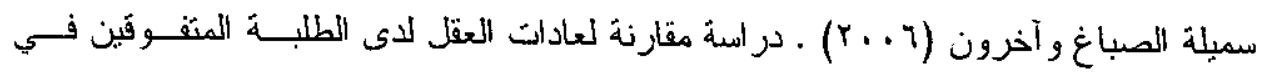
المملكة العربية المسعودية ونظر ائهم في الأزين.

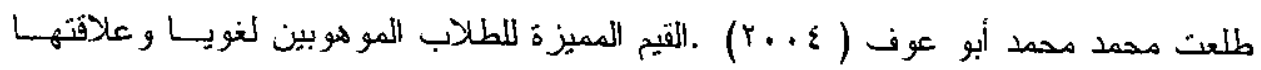
ببعض المنتير ات "دكتور اه كلية التزبية بسو هاج - جامعة جنوب التو ادي.

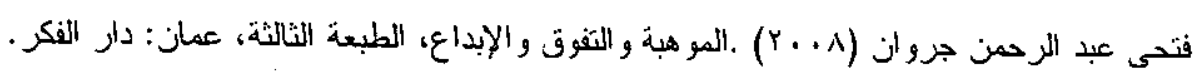

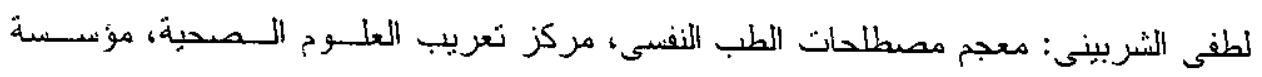
الكو بث للنقدم المعلمى. محمد عبد الرحيم عدس (990 19) .فن الإلقاء.القاهرة: دار الفكر .

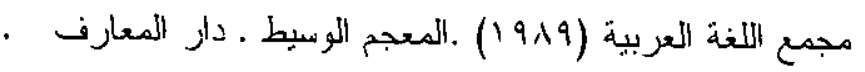
المؤنمر القومى للمو هو بين بجمهورية مصر العربية، ابربل عام . . . بج.

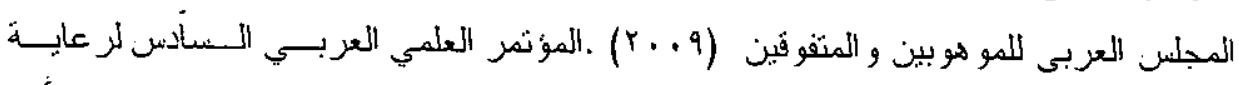

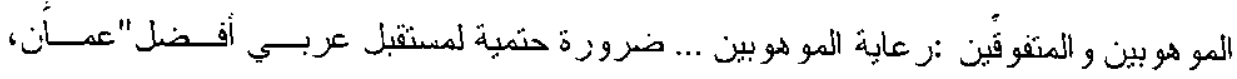
الأرندن.

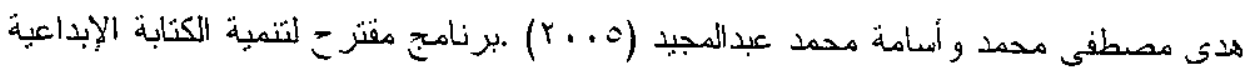

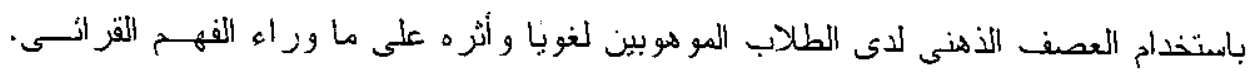

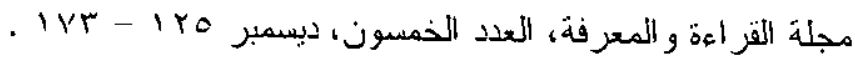

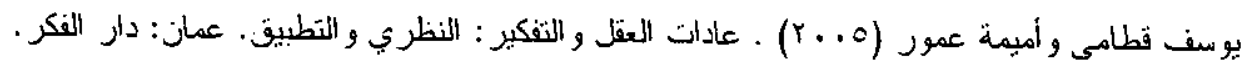



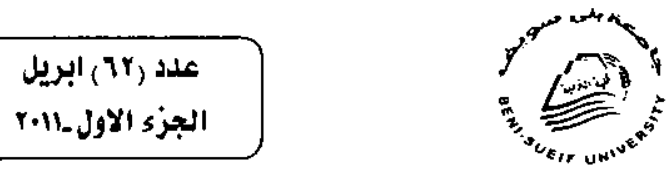

جامعة بني سيويف

بجلة كلية التريبة

ثانيا: المر اجع الأحنيية:

Adams. C. (2006) . PowerPoint. habits of mind and classroom culture. Journal of curriculum studies. Vol. 38. No. 4. Pp: 389-411.

Arthur L. Costa and Bena Kallick (2005) . Habits of Mind"A Curriculum for Community High School of Vermont Students "Based on Habits of Mind: A Developmental Series

Brice, Alejandro (2005). What Language Discourse Tells Us about Bilingual Adolescents: A Study of Students in Gifted Programs and Students in General Education Programs. Journal for the Education of the Gifted, v32, n1 p7-33.

Burgess, Jill (2011). The Impact of Teaching Thinking Skills as Habits of Mind to Young Children with Challenging Behaviours Emotional \& Behavioural Difficulties, v17 n1 p47-63

Butler, Gillian, Hope, Tony(1995). Managing your mind. The mental fitness guide. Oxford paper backs.

Eva, g .2002). Toward Dynamic Assessment of Reading : Applying Metacognitive Awareness Guide to Reading Assessment Tests. Journal of Reading .Vol (22), P .283-298.

Gardner, H. (1983). Frame of Mind: The Theory of Multiple Intelligences .New York: Basic Books.

Gardner, H. (1997): Creating Minds: An Anatomy of Creativity as Seen Through the Lives of Freud, Einstein, Picasso, Stravinsky, Eliot, Graham, and Gandhi"Basic Books

Goldenberg, E. Paul; (2010) .Developing Mathematical Habits of Mind. Mathematics Teaching in the Middle School, v15 n9 p505509 May.

Goldenberg, E. Paul; (2010). Organizing a Curriculum around Mathematical Habits of Mind Mathematics Teacher, v103 n9 p682688 May.

Goldenberg, E. Paul; (2010) . An Algebraic-Habits-of-Mind Perspective on Elementary School. Teaching Children Mathematics, v16 n9 p548-556 May.

Gordon, Marshall (201.) . Mathematical Habits of Mind: Promoting Students' Thoughtful Considerations . Journal of Curriculum Studies, v43 n4 p457-469 


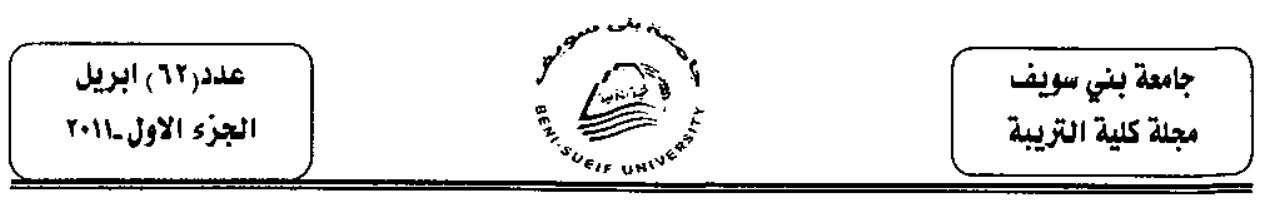

Hayes, Phebe (1998). Evidence of Language Problems in Underachieving Gifted Adolescents: Implications for Assessment." Journal of Secondary Gifted Education, v9 n4 p179-94 Sum.

Hew, Khe Foon (201.). Student Facilitators' Habits of Mind and Their Influences on Higher-Level Knowledge Construction Occurrences in Online Discussions: A Case Study" Innovations in Education and Teaching International, v48 n3 p275-285.

Kennedy, Dorothy M (1994): "Finding and Nurturing Verbal Talent: Hidden Talents Require Discovery. " Journal of Secondary Gifted Education, v5 n2 p19-22 Win.

Lee, Seon-Young; (2010): Achievement after Participation in a Preparatory Program for Verbally Talented Students Roeper Review, v32 n3 p150-163.

Matthews, Michael S (201.). Evaluating Gifted Identification Practice: Aptitude Testing and Linguistically Diverse Learners , Journal of Applied School Psychology, v27 n2 p155-180.

Mishra, Punya; Koehler, (201.). The Seven Trans-Disciplinary Habits of Mind: Extending the TPACK Framework towards $21 \mathrm{st}$ Century Learning Educational Technology, v51 n2 p22-28 MarApr.

Perkins, D.N. (2001). Educating for insight education leadership. 49 (2) 4-8.

Piirto, J. (1992). Does writing prodigy exist? In N. Gonlangelo \& S. G. Assouline \& D. L. Ambroson (Eds.), Talent Development ( $p$ p. 387-388). Unionvilla, NY: Trillium Press.

Rotta, (2004): All students can learn. App. Students can succeed. Alexandria, VA. ASC.

Sherman, Lawrence W.; And Others (1991)Written Language in Exceptional Male Elementary School Children: A Comparative Analysis of the Learning Disabled/Gifted.

Speeches/Meeting Papers; Reports - Research.

(ED341187)

Taylor, Simone Himbeault (201.). Engendering Habits of Mind and Heart through Integrative Learning. About Campus, v16 n5 p13-20 Nov-Dec . 


$$
\begin{aligned}
& \text { علد (rا }
\end{aligned}
$$

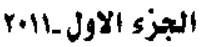

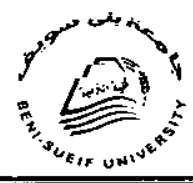

جامعة بني سوريف

مجلة كلية التريبة

Van Tassel-Baska, Joyc (2002). Assessment of Gifted Student Learning in the Language Arts . Journal of Secondary Gifted Education, v13 n2 p67-72 Win.

VanTassel-Baska, Joyce (2002). A Curriculum Study of GiftedStudent Learning in the Language Arts . Gifted Child Quarterly, v46 n1 p30-44 Win.

Villani, Christine J (1998):. Meeting the Needs of the Gifted Student in Language Arts and Mathematics: An Evaluative Exploration. Reports - Evaluative; Speeches/Meeting Papers Eric (ED420939) 